\title{
WV public school music teachers' use of digital audio technologies for teaching and learning
}

Mark R. Williams

West Virginia University

Follow this and additional works at: https://researchrepository.wvu.edu/etd

\section{Recommended Citation}

Williams, Mark R., "WV public school music teachers' use of digital audio technologies for teaching and learning" (2009). Graduate Theses, Dissertations, and Problem Reports. 2910.

https://researchrepository.wvu.edu/etd/2910

This Dissertation is protected by copyright and/or related rights. It has been brought to you by the The Research Repository @ WVU with permission from the rights-holder(s). You are free to use this Dissertation in any way that is permitted by the copyright and related rights legislation that applies to your use. For other uses you must obtain permission from the rights-holder(s) directly, unless additional rights are indicated by a Creative Commons license in the record and/ or on the work itself. This Dissertation has been accepted for inclusion in WVU Graduate Theses, Dissertations, and Problem Reports collection by an authorized administrator of The Research Repository @ WVU.

For more information, please contact researchrepository@mail.wvu.edu. 


\title{
WV Public School Music Teachers' Use of Digital Audio Technologies for Teaching and Learning
}

\author{
Mark R. Williams \\ Dissertation submitted to the \\ College of Human Resources and Education \\ at West Virginia University \\ in partial fulfillment of the requirements \\ for the degree of \\ Doctor of Education \\ in \\ Technology Education Program \\ Dr. Neal Shambaugh, Ph.D., Chair \\ Dr. Cheryl Prichard, Ed.D. \\ Dr. Jaci Webb-Dempsey, Ph.D. \\ Dr. Paul Chapman, Ph.D. \\ Dr. Richard Brown, Ph.D. \\ Department of Technology, Learning, and Culture \\ Morgantown, West Virginia
}

2009

Keywords: Music Technology; Music Education; Digital Audio; MIDI

Copyright 2009 Mark R. Williams 


\begin{abstract}
WV Public School Music Teachers' Use of Digital Audio Technologies for Teaching and Learning
\end{abstract}

Mark R. Williams

The wealth of new digital audio technologies, when implemented in classroom music instruction, has the potential to support increased student engagement and enhancement of the musical experience more than in any other time in the 100 year history of public school music education. The purpose of this study was to identify if digital audio technologies are currently being used by WV music teachers, their skill levels, what decisions are made when using the technology, what was the effect on learning, and to gauge whether teaching practices were changed. It is a picture of what teachers are currently doing as well as the barriers they have faced.

The study employed both quantitative and qualitative research methodologies. The quantitative instrument used was an on-line survey titled Use of Digital Audio Technologies in Teaching Environments. The qualitative component was interviews of K-12 music teachers who rated their digital audio technology use as high and experienced. Classroom observations also contributed to the study. The main elements characterized the current status of digital audio use and its' implications.

While migration to Compact Disc as a source of audio is the accepted norm in West Virginia, very few teachers currently utilize other sources of digital audio formats. Similarly, while electronic keyboards are commonplace in classrooms, a significant number of teachers do not use MIDI applications or functions. Skill attainment and decisions to integrate digital audio technologies face three barriers. Teachers believe a lack of significant funding and content appropriate training has equally served as obstacles towards their adoption and integration of many audio technologies. Existing infrastructure has contributed to this challenge.

Decisions to use digital audio technologies in teaching are met proactively with the teachers embracing the wealth of new content, the positive and immediate receptiveness with their students, and the assistance gained in meeting both state and national content objectives. Music teachers in West Virginia are cognizant that there is a different type of student learner and are beginning to modify their delivery methodology and teaching strategies appropriately.

This study shows the current applications of digital audio technologies in WV music classrooms as a snapshot of what is currently being used. It illustrates that WV music teachers, while aware of the changes in type of learner and learning style, as well as the benefit of audio technology use, are not using, as a collective, digital audio technologies in many contemporary ways. 
Acknowledgements

I wish to offer my sincere thanks and gratitude to all of my committee members, Dr. Richard Brown, Dr. Paul Chapman, Dr. Cheryl Prichard, and Dr. Jaci WebbDempsey, who always had words of encouragement, exhibited incredible patience, and consistently exhibited enthusiasm through my multiple attempts at completing this document. To my chair, Dr. Neal Shambaugh, from the beginning of my involvement at West Virginia University, your teaching, advice, and unceasing willingness to guide me, no matter how sporadic I was, has been of such incredible value to me. You have taught me persistence, continual pursuit of excellence, and compassion when "life" gets in the way. Thank you!

The instruction and mentoring of my committee, along with former faculty members of the Technology Education Program, has been truly inspirational. I continually try to emulate, in my own teaching, the catalyst of curiosity and excellence in engagement you provided for me. My sincere appreciation is also extended to Dr. Ernest Goeres for your last minute support and interest.

To my colleagues and fellow West Virginia teachers who participated in this study, your expressions of respect and encouragement were truly humbling and motivational. The genuine dedication you continually exhibit and the sincerity in your beliefs of the benefits of quality music education serve our students well.

I wish to acknowledge my late Mother and Father, whose lack of formal education belied their own never-ending desire to question, learn, and discover. Additionally, I express my gratitude to my sisters who never let their "little brother" off the hook in fulfilling this completion. 
My family has been steadfast in their support of me. To Cheryl, my biggest cheerleader, and Blake and Michelle, who continually expressed their pride in me, I cannot thank you enough. I love you guys! 
Table of Contents

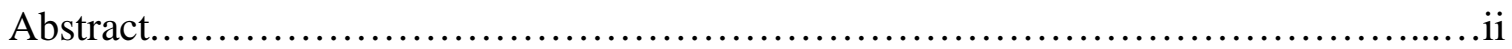

Acknowledgements........................................................ii

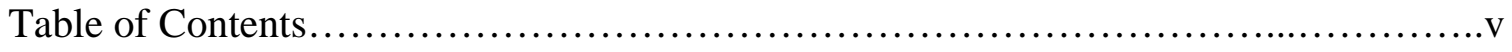

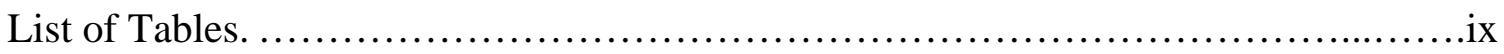

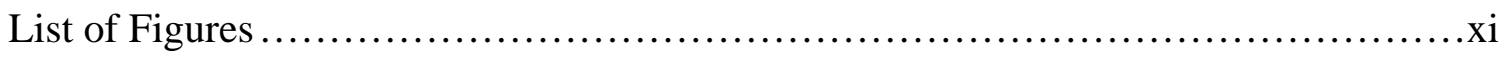

Chapter 1 - Introduction...................................................

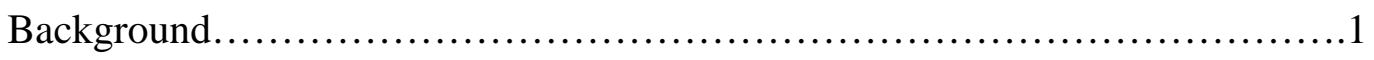

Rationale..............................................................4

Purpose.............................................................6

Research Questions...................................................6

Definitions of Terms................................................

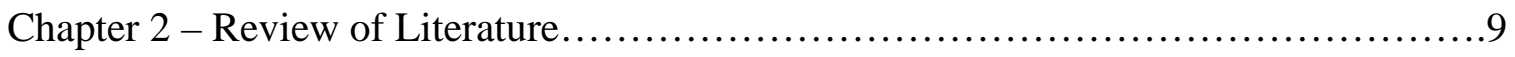

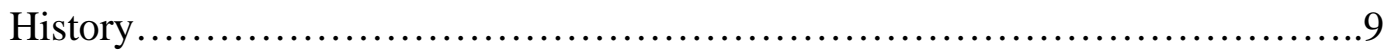

Music Educators Migration to Digital Technology............................16

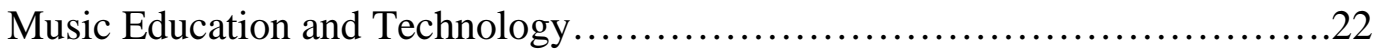

Research on Music Teaching with Technology.............................31

Chapter 3 - Method........................................................ 37

Introduction...................................................... 37

Participants...........................................................

Data Sources......................................................39

Data Collection......................................................41

Survey.....................................................41 


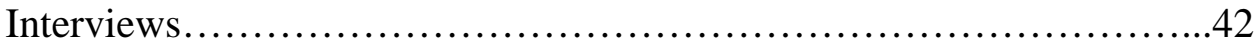

Observations........................................................ 42

Data Organization and Analysis...........................................42

Limitations................................................................

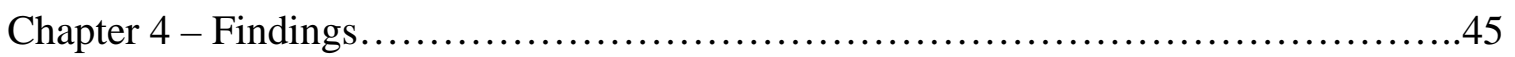

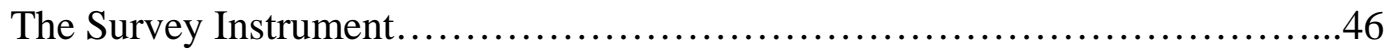

Research Question 1: Demographics.....................................46

Demographic Information..........................................46

Research Question 2: Use of Digital Audio Technologies in Music Teaching

Environments............................................................ 48

Audio Formats.....................................................48

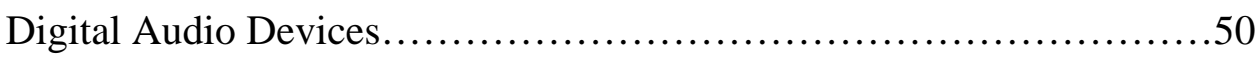

Digital Audio Processes.............................................52

Digital Audio Software ............................................57

Research Question 3: Digital Audio Technology Skills.........................59

Teaching Decisions ..................................................63

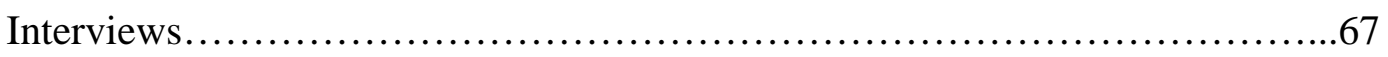

Research Question 3: Teachers Skills and Knowledge..........................69

Comfort Level.....................................................69

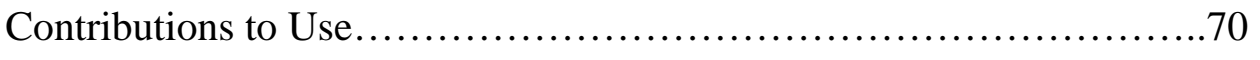

Barriers.............................................................

Skills..................................................................

Research Question 4: Teaching Decisions and Impact on Learning...............77 
Access to Content................................................80

Teaching Methodology..............................................80

Specific Applications............................................81

Research Question 5: Teaching Practices................................82

Content and Materials..........................................83

Efficiency......................................................84

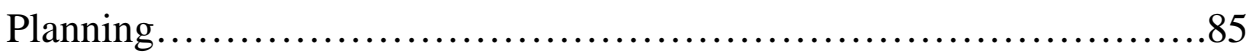

Changing From Old to New.......................................86

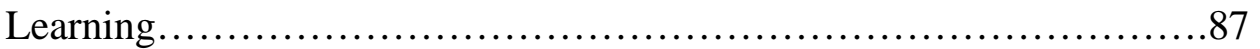

New Materials....................................................88

Engagement....................................................89

Student Receptiveness..........................................90

Reevaluation of Teaching.......................................92

Assessment......................................................... 94

Observations......................................................... 96

Summary of Analysis................................................ 100

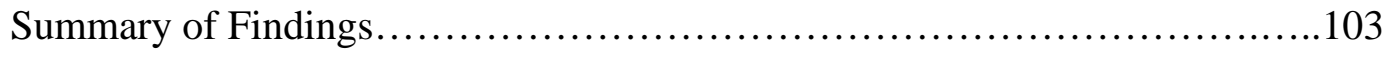

Chapter 5 - Conclusions, Implications, Future Research........................110

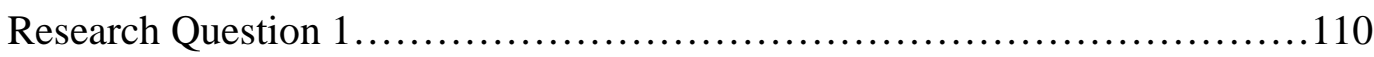

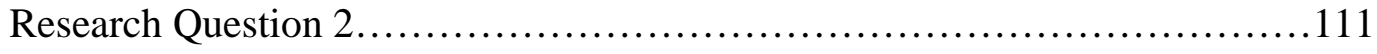

Research Question 3...............................................112

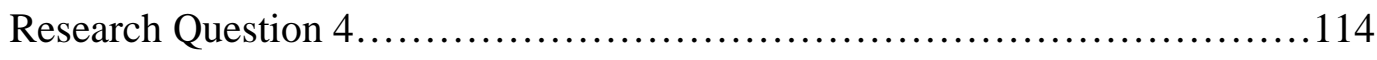

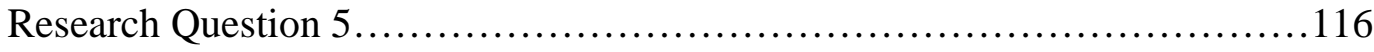


Implications.......................................................... 118

Limitations.............................................................. 121

Recommendations for Practice.......................................122

Further Research...................................................... 128

References..............................................................131

Appendices................................................................... 142

Appendix A - Survey of Digital Audio Technologies for Teaching and

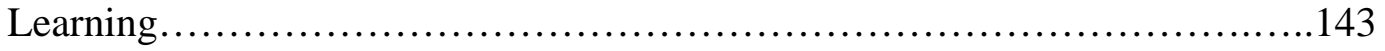

Appendix B - Interview Protocol........................................149

Appendix C - Observation Elements...................................152

Appendix D - Institutional Review Board Exemption........................154 


\section{List of Tables}

Table 1 Summary of Sources and Analysis...........................................40

Table 2 Demographic Profile of Participants.................................... 47

Table 3 Use of Audio Format....................................................49

Table 4 Use of Digital Audio Devices...............................................51

Table 5 Use of Digital Audio Processes and Activities...............................55

Table 6 Use of Digital Audio Technology Software....................................59

Table 7 Self Rating of Current Abilities with Digital Audio Technologies.................61

Table 8 Responses Regarding Education and Teaching Decisions.....................65

Table 9 Demographics of Interview Participants, Areas(s) of Instruction, and Years

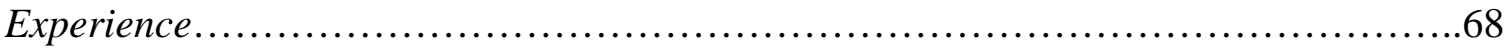

Table 10 Recurring themes and keywords within skill acquisition.....................76

Table 11 Specific Applications Quoted in Interview Question 4.......................82

Table 12 Comparison of Older Technologies. Methodologies, and Expectations to the

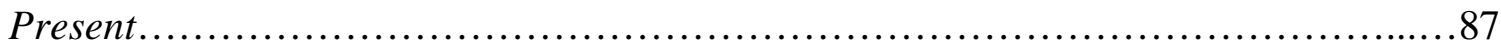

Table 13 Commentary Regarding No Change, Slight change, and Significant Change of

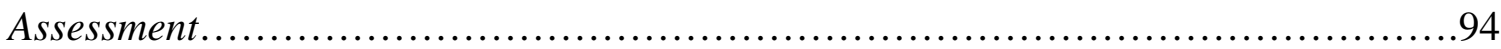

Table 14 Summary of Observations ...............................................99

Table 15 Summary of Data Sources and Data Analysis..............................102

Table 16 Research Question 1 Summary.....................................103

Table 17 Research Question 2 Summary........................................104

Table 18 Research Question 3 Summary........................................105

Table 19 Research Question 4 Summary.......................................107 
Table 20 Research Question 5 Summary.........................................108 


\section{List of Figures}

Figure 1. Primary changes in instruments and recording technology. ..................10

Figure 2. Percentage of Respondents Who Use Daily or Never Use an Audio Format....50

Figure 3. Creation and Dissemination of Audio Material.............................53

Figure 4. Purchase and Use of CD-ROM, Audio Files, and MIDI Files..................54

Figure 5. Sources of Audio Files..............................................55

Figure 6. Audio Software Use at Any Time....................................58

Figure 7. Teachers who have never tried or rated their skills as beginner, in using digital audio technologies.........................................................63

Figure 8. Recurring themes citing barriers to technology use by grade level. ...........74

Figure 9. Digital technology uses by frequency of keyword. .........................78 


\section{Chapter 1}

Introduction

The use of any technology entails a need for constant training and self-instruction on the part of the teacher and implies professional motivation and challenge.

Furthermore, when teachers introduce technology into the classroom, important changes occur in teaching and learning. A significant transition for music educators has been the move from traditional analog audio sources to the total digitization of this necessary teaching resource. During the last twenty years a large number of different audio technologies and web-based interfaces have been developed. Today they offer sophisticated possibilities to access, analyze, process, create, and distribute sound both synchronously and asynchronously.

These recent technologies have made it possible to create ownership of all parameters of audio material, modify its interpretation or context, and provide numerous distribution methodologies, all without boundaries, if given the right teacher skill set. The potential of digital audio technology in creating learning opportunities and activities that could not be accomplished as easily without the technology has resulted in a new genre of content standards as well as rapid inclusion in "in-service” and teacher preparatory curriculums.

Background

Riemer (1989a) describes two revolutionary changes in the process of music education as caused by a revolution in computer technology. One change is how people can be involved more readily in the art of music and the second affecting how education can be made more effective as a result of the technology. Mauricio and Oppenheimer 
(2005) state that two of the most important developments in music technology during the 20th century were digital audio and the Musical Instrument Digital Interface (MIDI). These developments have an ever-increasing impact on the way we create, perform, and listen to music in classrooms. MIDI is useful because MIDI files only contain performance instructions; thus the file sizes are significantly smaller than digital audio files. MIDI recording and editing is quite easy and requires less sophisticated computing power whereas audio signals are very complex. Both are easily manipulated and disseminated.

"MIDI may be best thought of as a protocol” (Deutsch, 1993, p. 79). For the classroom music educator, MIDI allows the multiple connections of sound devices regardless of manufacturer. In the context of this research MIDI functions shall be limited to the triggering of digital sounds, the manipulation of MIDI sequences either created or obtained, and the use of MIDI musical files in music instruction.

In the music-technology lab, electronic keyboards are commonly used for MIDI input (Rudolph, 2004). Some common reasons for using digital audio include the ability to record the actual sound of a performance, the quality of the fidelity, and the ability to disseminate via self recorded compact discs or streamed via the Internet. Digital sampling is a form of recording, but unlike analog recording, it is a procedure where sound waves are represented by digital patterns. In this process, analog audio sound waves are sampled thousands of times by a microprocessor. The various complex waveforms are stored and manipulated as digital information. When processed through a Digital to Analog Converter (e.g. Compact Disc Player) they may be heard by the listener. 
Once music files are converted to digital form and compressed in formats like MP3 they can easily be exchanged over the Internet or by "burning” (recording them onto CD or DVD). A dramatic change is taking place with a move away from music albums to the purchase of individual digital tracks purchased over the Internet. Printed music has also been transformed. Teachers can view and listen to scores via Internet streaming, purchase, and download them to their computers for printing.

Modern music technology provides teachers and students alike with a wide range of products and applications for using digital audio and MIDI. This electronic technological revolution has redefined the world of music in performance, composition, and education. There is an emerging age of technology that incorporates high quality sound as well as sophisticated interactive instructional capabilities (Willman, 1992).

These capabilities are becoming more affordable and accessible to a much wider population than ever before. Evidence of this technological explosion is reported in overwhelming sales of keyboard synthesizers, computers, CD-ROM disks, and on-line Internet users. By 1989 sales reports confirmed that over 17 million keyboards and synthesizers were owned by Americans (Bash, 1990). Music product sales are an approximate $\$ 7$ billion industry in the US, according to the National Association of Music Merchants (NAMM, 1996) The global market recently reached \$15.4 billion in total annual sales. Music products are sold in over 8 thousand music retail stores in the US and over 17.8 thousand globally. The industry has consistently grown at a steady rate of $6 \%$ annually. With increasing digital and on-line distribution of music, significant additional growth is expected. Apple’s iPod sales are up 61\% from 1 year ago with 8.5 million iPods sold in the 2nd Quarter of 2006. Niche sheet music market is expected to 
mirror the Digital Audio Player market which should experience 400\% growth by 2009 and the digital download market which anticipates a 134\% growth rate in 2010.

\section{Rationale}

In order to gauge the progress of technology in music education at a later date, it is essential to mark achievement thus far (Meltzer, 2001). Accurate statistics on how music technology is currently used are needed to facilitate the planning of music curricula (Reese \& Rimington, 2000). Examining the use of digital technologies is becoming increasingly important with the establishment of new guidelines for teacher skills and knowledge in using music technology into classroom practice.

New standards for all teachers have been produced by organizations such as the National Council for Accreditation of Teacher Education (NCATE, 2000) and the International Society for Technology in Education (ISTE, 2000). Technology competencies for music educators have been delineated by the Technology Institute for Music Educators (Rudolph, Richmond, Mash, \& Williams, 1997). MENC: The National Association for Music Education has also established benchmarks for using music technology in regards to its impact on curriculum, staffing, equipment, materials, and facilities (MENC, 1999). As early as 1983 (Franklin, 1983), called for a standard definition of technology literacy within the music education profession.

The development of pre-service college courses addressing this need is growing (Bowman, 1990). Evidence that music technology courses are being offered at colleges and universities across the country can be found in college catalogs and web pages, and through national (Schmidt, 1989) and regional (Wollenzien, 1999) surveys. One study (Tredway 1994) attempted to identify which technologies were being used within the 
Florida Music Educators Association. The areas of technology identified included tape recording, MIDI computer sequencing, and notation.

Using technology to teach music has numerous advantages (Kassner, 1998) and should play a more prominent role in music education at all levels (Williams \& Webster, 1999). It is well documented that integrating technology into the music curriculum is very effective (Bartram, 2001; Rudolph, 2004). Music educators are probably not using music technology to its greatest potential (Bremer, 1999; Meltzer \& Reese, 1999). Resistance to utilize music technology often exists because of inadequate training, inadequate funding, or the lack of time needed to gain the skills needed (Bartram, 2001). Contributing to the difficulty of integrating technology into the music classroom is the absence of current curriculum materials with a musical focus (Jaeschke, 1996). The Cawelti and Goldberg (1997) report revealed a need for music researchers to conduct studies which examine the impact of existing technology upon music pedagogy.

This writer contends that digital music technologies are ubiquitous and the skill set needed to access and use them in education is sufficiently available to be obtained by music teachers. This includes inclusion in teacher training curriculum, professional development activities, peer tutelage, and student to teacher mentoring. Higgins (1992) states that the development of technologies and adapting them to music instruction has been extensive, both in the academic community and the music industry. Higgins also indicates that it is accurate to state from the outset, that any research in the use of technology in music education has however been limited. One rationale for such a lack of research can be attributed to the rapid changes taking place in the field of technology. 
Purpose

This wealth of new digital tools, when used appropriately, has the potential to support increased student engagement and enhancement of the musical experience more than in any other time in the 100 year history of public school music education. Responding to this growth, The Technology Institute for Music Educators has divided technology into seven primary areas. The researcher has chosen to focus on the newest of these areas; digital audio and MIDI related technologies.

The purpose of this study was to identify which digital audio technologies are currently being used by WV music teachers, what influenced the technology use, what was the effect on learning, and what were the barriers to preventing more teachers from incorporating the technology. The objectives of the study are reflected in the following research questions:

Research questions

RQ1: What are the demographic characteristics of WV public school music teachers who use digital audio technologies?

RQ2: What digital audio technologies are being used in music teaching environments?

RQ3: What skills have WV public school music teachers acquired to utilize digital audio technologies for access, manipulation, dissemination, and use in teaching music education?

RQ4: What teaching decisions are made when using digital audio technologies and what impact do they have on student learning?

RQ5: Has the use of digital audio technologies changed the teaching practices of WV public school music teachers? 


\section{Definition of Terms}

The following terms have been used in this research:

Analog: An abbreviation for analogous, meaning that information is stored in a way similar to, or resemble the original (Rudolph, 2004). An example of analog wave forms can be found with records and cassette tapes.

Audio Interface: Converts analog information into digital information permitting communication to a computer or other digital device.

CD Burner: A device used to create compact discs from digital information or files.

$C D-R O M$ : A compact disc with read only memory.

DAT: Digital audio tape. A magnetic tape device which functions similarly to an analog cassette deck. Records and playbacks information in digital audio formats.

Digital Audio: An audio signal which is stored, recorded, processed or amplified in digital or numerical form. The numeric representation of sound. Typically used as the means for storing sound information in a computer or sampler (Cakewalk, 2008).

Digital Keyboard/Synthesizers: The use of numbers to create sounds. Method most often used in today's synthesizers for generating sounds, as compared to analog method employed previously (Cakewalk, 2008).

Download: Information copied from the Internet or another computer to another computer.

iPod: A portable music player developed by Apple Computer. Supports a wide variety of audio formats, including MP3, AAC, WAV, and AIFF. 
iTunes: an audio playback program developed by Apple Computer for both Macintosh and Windows operating systems.

MIDI: The Musical Instrument Digital Interface. A standardized computer language that permits communication between multiple electronic musical instruments and/or with a computer.

MIDI File: Performance information that is stored in computer file format (Rudolph, 2004).

MP3: MPEG-1, audio layer 3, is a form of digital audio file compression that reduces the size of audio files without drastically compromising sound quality. MP3s reduce unnecessary data that is imperceptible to the human ear (Hewlett-Packard, 2008).

Podcast: Audio and video broadcasts that can be played on an iPod or played directly within a computer program such as iTunes.

Sampler: An electronic device that can record, edit, and playback digital audio data under the control of a MIDI data stream. Individual sounds are referred to as samples (Cakewalk, 2008).

Sequencer: MIDI software or less commonly, a hardware device that can record, edit, and playback a sequence of MIDI data (Cakewalk, 2008).

Software Synthesizer: Uses the same process as an external digital synthesizer except that it uses the memory and storage capability of the computer (Rudolph, 2004).

Streaming Audio: Live audio received over the Internet without downloading it. Streaming does not save a copy of the audio on your PC, while downloading a file does. Internet radio stations generally use streaming audio to broadcast (Hewlett-Packard, 2008). 


\section{Chapter 2}

Review of Literature

The following section provides a review of literature related to this research. The literature examines four primary factors regarding digital audio technologies in education. The first part examines the recent history of audio technologies. The second part examines evidence and issues regarding the adoption of digital technologies in music education. The third part examines the relevance and issues surrounding digital audio technologies in public school music education. The final part examines research regarding the impact that the integration of technology on the music education community.

History

Although sound recording technologies have been the biggest technological change effecting music education this century, the other major area of technological development throughout the history of music has been in the improvement of musical instruments (Brown, 1995). Music philosopher Theodor Adorno (as cited in Braun, 2002) described an increasing advancement of music technology in both music reproduction and music production. Significant historical development in both of these areas can be found in the writing of Braun (2002), Webster (2002), Williams and Webster (1999), and the web pages of Crab (1995) and Schoenherr (2005). All acknowledge a primary third influence, this being the rapid adoption and integration of computers and the Internet in education. Figure 1 is a summary of developments germane to this study. 
Figure 1. Primary changes in instruments and recording technology.

\begin{tabular}{|c|c|c|}
\hline Date & Development & Area of Influence \\
\hline 1877 & Thomas Edison Invents the Phonograph & Recording \\
\hline 1895 & $\begin{array}{l}\text { Player Piano and other machines use air and spring driven } \\
\text { power to make music }\end{array}$ & Instruments \\
\hline 1906 & Thadeus Cahill builds the Telharmonium & Instruments \\
\hline 1906 & $\begin{array}{l}\text { The Vacuum Tube leads to the development of new } \\
\text { amplification methods. }\end{array}$ & Instruments/Recording \\
\hline 1917 & Theremin invented & Instruments \\
\hline $\begin{array}{l}1932- \\
1950\end{array}$ & $\begin{array}{l}\text { Electronic instruments, which include the Hammond organ } \\
\text { and the Rangertone organ }\end{array}$ & Instruments \\
\hline 1932 & $\begin{array}{l}1932 \text { - BASF of I.G. Farben joined with AEG of Telefunken } \\
\text { to develop magnetic tape recording }\end{array}$ & Recording \\
\hline 1936 & $\begin{array}{l}\text { First BASF/AEG tape recording on Nov.19 of live concert by } \\
\text { Sir Thomas Beecham. }\end{array}$ & Recording \\
\hline 1939 & Independent invention of the wire recorder in U.S. & Recording \\
\hline 1944 & 1944 - 3M Co. begins tape coating experiments in U.S. & Recording \\
\hline 1947 & Invention of the Transistor & Instruments/Recording \\
\hline 1948 & 1st U.S.-made Ampex Model 200 tape recorders & Recording \\
\hline 1963 & Philips demonstrated its first compact audio cassette & Recording \\
\hline 1963 & $\begin{array}{l}\text { Robert Moog and Don Buchla develop commercially } \\
\text { successful synthesizers }\end{array}$ & Instrument \\
\hline 1967 & Integrated Circuit patented & All \\
\hline 1970s & $\begin{array}{l}\text { Computer Technology becomes affordable enough for } \\
\text { purchase by school systems }\end{array}$ & Computer \\
\hline 1977 & The Synclavier was invented utilizing sound samples & Instrument \\
\hline 1982 & $\begin{array}{l}\text { First digital audio 5-inch CD discs marketed, merging the } \\
\text { consumer music industry with the computer revolution }\end{array}$ & Recording/Computer \\
\hline 1983 & $\begin{array}{l}\text { The Musical Instrument Digital Interface protocol is } \\
\text { introduced }\end{array}$ & Instruments/Computer \\
\hline 1985 & $\begin{array}{l}\text { Laser-Driven CD-ROM drives that can play audio CDs are } \\
\text { developed }\end{array}$ & Recording \\
\hline 1985 & $\begin{array}{l}\text { Sony and Philips produced the standard for Compact Disc } \\
\text { Read Only Memory (CD-ROM) computer discs. }\end{array}$ & Computer \\
\hline 1985 & Digital Synthesizer and Samplers available in U.S. & Instruments \\
\hline 1987 & Digital Audio Tape (DAT) players introduced & Recording \\
\hline 1995- & $\begin{array}{l}\text { Educators use digital audio software to record and process } \\
\text { sound }\end{array}$ & Recording/Computer \\
\hline 1995- & $\begin{array}{l}\text { Teaching materials, recorded music, and published music } \\
\text { become available on the Internet }\end{array}$ & Internet \\
\hline 2001- & iPod and Podcasts & Recording/Internet \\
\hline
\end{tabular}


A review of this history demonstrates technology’s role in music education. With the invention of the phonograph, Edison changed our expectations for communications and the delivery of music Instruction (Webster, 2002).

The telharmonium employed numerous gears and levers and inductors to produce alternating currents to different frequencies. The telharmonium was only experimental and had little practical success. The player piano did meet with great success as it lifted performances out of the concert hall and into homes. This was possible because it treated music as information storing the data on piano rolls. For many years the player piano rivaled the gramophone (Braun, 2002). Educator Ashton Johnson when asked his opinion of the player piano considered it as a great aid to fine appreciation of music. He found that the "pianola” was being used systematically in universities and over two hundred leading schools to educate not only musical students but all pupils (Jonson, 1915-1916). He observed that children were stimulated to learn music when engaged with the instrument. Jonson surmised that the increase in interest generated by player piano use by teachers would be a significant benefit to the teaching profession.

Reviews of the very first issues of the Music Supervisors Journal include advertisements for victrolas and for a series of recordings from the company which would become RCA (Hoover, 1975). The evolution of recorded sound technology was utilized by publishing companies to target recordings toward schools and universities (Garofalo, 1999). By 1938 a case for recording was made by educators. Citing that phonographs and radios have found their way into every music room, so should the recording machine have a legitimate place in the musical equipment of every school 
system. Its many possibilities included the purpose of measuring and proving ones own work and for the purpose or preserving what is good (Birge et al., 1938).

In 1951, music educator Charles Leonhard provided a summation of the integration and use of records in public school music education. He stressed that through years the record player and recordings have become standard items of equipment for the teacher of music. No one would question the value of recordings when they are used in their proper setting. Leonhard listed the educational uses of recordings in shaping the setting of the learning environment, use for illustrative purposes, demonstration of performance goals, enrichment of context, and the uniqueness of the resource within the classroom (Leonhard, 1951).

Leading music educator Bennett Riemer (1989b) continued to encourage the use of technology. Riemer wrote that educators should not promote the indiscriminate use of technological devices, but to promote the wide and good use of those devices that will help to do better. His article commented on the size and use of tape recorders and their remarkable stage of development. "Some are so portable that they can even be put in a handbag or briefcase.” Tape editing devices are available at low cost so that teachers can make changes in tapes. Likewise, sound filters, tone generators, and oscilloscopes for visual reference of sound waves exist. These can be used to explain technical (amplitude, frequency, and quality) aspects of music.

As sound reproduction moved from vinyl to cassette, educational products with audio reinforcement began to appear (Feldstein, 2001). When Compact Disc technology became available, publishers adopted CD distribution as a means to develop educational products which gave authors the opportunities to aurally demonstrate what they were 
teaching, and provided play along experiences (Feldstein, 2001). Educators and consumers alike readily adopted CD technology. In 1988, for the first time, CD sales surpassed LP sales, leaving CD and cassette as the two dominant formats (Schoenerr, 2005).

If sounds could be changed electronically, they could also be produced electronically. The instrument developed for creating sound was called a synthesizer (Wagner, 1988). As a result of the creation of the vacuum-tube oscillator the first generation of synthesizers became the earliest form of electronic performing instruments. Because of their size, most were confined to centers of musical experimentation primarily colleges and universities (Williams and Webster, 1999). The synthesizer itself has been undergoing a metamorphosis. Because of electronic miniaturization and specialization, bits and pieces of synthesizers and the older electronic organs have become the workings of electronic keyboards. Synthesizer sound production has progressed from tubes to transistors to microchips and from analog to digital (Wagner, 1988).

Music instrument manufacturer Yamaha’s role in the development of musical instruments is one of creative adoption, in which ingenious marketing methods and an emphasis on music education played an important role (Braun, 2002). The DX7 synthesizer was the first truly digital synthesizer and was released with great commercial success in 1983, selling over 180,000 units. The DX7 used a type of synthesis Yamaha called "Frequency Modulation" developed by Professor John Chowning at Stanford University in the 1970s (Crab, 1995). Digital synthesizers treat sounds the way computers manipulate symbols. Contemporary digital technology is based, in the main, on microprocessor controlled devices. Microprocessors are at the heart of compact disc 
players, modern audio recorders and music synthesizers. The foundation of such music technology is the digital representation of sound (Brown, 1995). The sampling techniques of the 1980s made it possible to treat all sound as data: once sampled, anything could be reshaped and reproduced.

Since the Musical Instrument Digital Interface (MIDI) first entered the market in 1983, producing music software and hardware for educational purposes has been a primary goal of manufacturers and programmers (Bartram, 2001). Bartram says that in 1998, the musical instrument most in demand was that which allowed the use of MIDI. Music technology has become associated with the computer because of its capacity to process, store, and retrieve information. The computer also has non-linear characteristics that make possible achievements in the field of sound manipulation (Van Regenmorter, 1998) thus opening the door for increased digital audio access, editing, and dissemination. The computer can facilitate performances in MIDI environments. Often this practice is referred to in the category of computer-based instruction (Williams \& Webster, 1999). MIDI enables communication between electronic musical instruments manufactured by various companies and between the instrument and the computer. Writing as a teacher-researcher, Reese (1995) maintains that students develop sensitivity, perceptiveness of the elements of music, and musical understanding through creative production of projects enabled by MIDI technology. Music creation is moving towards software which gives anyone instant access to what used to be expensive recording hardware. Inexpensive MIDI input devices can capture and convert almost all musical gestures (Rubin, 1995). Computer software designed as a result of the MIDI interface 
permitted the computer to use external synthesizers as sound sources as well as interactive partners in the learning process (Webster, 2002).

With the dawn of MP3 technology, educators can more readily download hundreds of sound files, obtaining copyrighted selections by permission from various sources, by mutual exchange of works with other educators, or access those in the public domain, all via the Internet (Liske, 1999). Liske supported the fact that there are a variety of web-based venues suited to being incorporated into instructors' music curricula. Powell and Artaud (2001) highlighted several advantages of using the Internet. Aside from being a means of distributing and promoting a musician's work inexpensively, it allows consumers/listeners more direct access to the artist and their work. This capability also poses a significant advantage for teachers and students, providing them with the means of introducing to each other new developments, artists, and recent trends in the music industry. Today, the Internet allows both teachers and students to quickly research historical and cultural backgrounds of particular works and their composers (Thompson, 1999).

Perhaps the most recent trend has been the rise of specific Internet-based materials for music teaching and learning. As teachers gain skills, music materials provided online are transforming both content and delivery strategies (Waters, 1999). Individuals and companies now routinely distribute recorded music on the Internet in the form of MPG3 files. Music notation companies have established procedures for purchasing published music from the Internet (Webster, 2002). As authors and publishers embrace the web, a wealth of teaching aids will become available, but only if educators seek them out and use them (Feldstein, 2001). Evidence of the rapid arrival and 
dissemination of digital technologies is perhaps most visible when ones looks at how new technologies have revolutionized the ways in which people perform, compose, share and purchase music. The power of the Internet allows users immediate access to and purchase of music from many genres, styles and traditions. Similarly, producers of music exploit the immediate and communicative potential of the Internet to artistically shape their output (Savage, 2005). One of the greatest influences on music studies is its ability to allow us to hear and think about music in new and enhanced ways. As a result it can change the way we understand music and provide new insights for the people who create it. This has been true for technological developments throughout history. Mumford (1952) observed that behind all the great material inventions of the last century and a half there was not merely a long internal development of technology but also a change of mind.

\section{Music Educators Migration to Digital Technology}

In recent times, many musicians, music educators, and music students have begun to employ some sort of computer-based technology in their musical lives. As Taylor states: "The advent of digital technology in the early 1980s marks the beginning of what is the most fundamental change in the history of Western Music since the invention of music notation in the ninth century” (Taylor, 2001, p. 3). Powerful computers and fast Internet connections have become affordable and widely available. The technology's advantage to manipulate audio has meant that many people, who up until now did not perceive themselves to be musicians, can handle, create and communicate music using their computers. Individuals can employ and manipulate inexpensive music software and hardware, which does not require 'traditional' musical 
skills or conceptual understanding (Crow, 2006).

As society becomes increasingly embroiled in digital media for representation and communication, our philosophies of music education need to adapt to integrate these developments while maintaining the essence of music. The foundation of music technology is the digital representation of sound. The fundamental shift to a new medium to represent sound carries the challenge to address digital technology and its multiple effects on music creation and presentation (Brown, 1995). The music educator is primarily concerned with audio experiences, both those produced by experts and those produced by his students. It would seem that the music educator would be most familiar with available devices and techniques for producing, recording, storing, distributing, and reproducing sounds (Wyman, 1966). Although sound recording technologies have been the biggest technological change effecting music education this century, digital technologies, in the form of computers and synthesizers are the most visible technological change with which we are currently engaged (Brown, 1997). The technological environment in which the student can develop is established by the teacher and the curriculum, so choosing engaging activities and appropriate technologies is vital (Rudolph, 2004).

Brown (1995) refers to technologies available to the music educator as printed documents, musical instruments, mechanical tools, electronic and digital audio devices, MIDI devices, computers, Internet, and the like. There are a number of electronic and digital technologies which, over the past few decades, music curricula have been challenged to incorporate. These include the tape recorder, CD, synthesizer, and the MIDI sequencer. The phonograph has radically changed the way music is experienced in 
our culture. Now we face a revolution equal in it musically transformative potential. Just as the phonograph allowed all people direct access to all music, so are developing computer technologies (Riemer, 1989a; Riemer, 1989b). Several years ago, when speaking of technology used in music education, one might have referred to the phonograph or cassette tape recorder (Rudolph, 2004).

As Rhee (2001) reported in her dissertation, in the late 1960s, music educators were dealing with the frustrations of using vinyl records and magnetic audiotapes to illustrate class material. Trying to locate a particular musical passage often wasted valuable class time. After multiple uses, records were often scratched and tapes rendered unusable. Once compact discs (CDs) were produced beginning in 1982, music educators had a new and reliable means of instructing their students. Citing better sound quality, systematic location schemes, and high durability, most teachers adopted CD integration rapidly. In 1997 it was reported that compact discs (CD’s) are already much more popular than cassette tapes (Rudolph, Richmond, Mash, \& Williams, 1997). Descriptive uses of compact discs suggest two ways in which respondents are utilizing CD's these being replacements for traditional records and as expanded technology tools (Stell, 1999). Respondents had seemingly replaced traditional records with compact discs. It was reported that enhanced instruction was possible with the use of CD's as opposed to the limited instructional methods possible with the use of traditional recordings. Accessibility to precise excerpts of music was a result of the digital status of compact discs. The fact that compact discs are digital means it permits random access of recorded material. Respondents also described electronic synthesizers with MIDI capabilities as being part of piano and keyboard laboratories and that they were being used for individualized and 
group instruction. Lastly, respondents stated that the employment of keyboard technology has resulted in expanded instructional strategies in general music classes.

Today the term "technology" is more likely applied to "digital” tools and equipment (Meltzer, 2001; Reese \& Rimington, 2000). The availability and quality of sound is a development which has recently made much progress and will have a tremendous impact on music education (Sebald, 2003a; Sebald, 2003b). Industrial and subsequent electronic technologies allowed for audio recordings of music to be made. Audio recording technology has been an invaluable tool for the student of music through most of the 20th century. Brown (1995) describes the progressive introduction of digital tools into music studies in 4 steps.

1. The use of electronic tuners and metronomes

2. The increased use of digital keyboards for non-concert performance roles created a computer based environment for the study of music

3. Wider use of digital sequencers and recorders to work along side the keyboards

4. The development of portable digital workstations and other portable devices Lin (2005) studied the effects of integrating music technology into music teaching and observed that teachers often use the Internet to find potential sources of repertoire, both by listening to streaming audio excerpts and by searching on-line catalogs. As the number of students who access the Internet grows daily, it has significant potential as a medium through which to teach music. Its integration into the classroom requires the instructor to be familiar with the many ways in which audio can be utilized when on-line. Other issues the instructor must take into consideration are real-time communication and copyright. 
Waters (1999) pointed out that although there are problems to be worked out to establish this as an everyday curricular tool, it is one that is both exciting and familiar to most students. Music technology is becoming increasingly popular in schools across the country as an effective and legitimate educational tool (Bartram, 2001; Hackett, 1997; Meltzer, 2001).

Peters (1992) parallels the development of computer based music instruction software programs for music classrooms with the rapid development of hardware and emerging technology. He frames software and emerging technology into "generations." Although limited to a small group of enthusiastic music educators and music theorists, Peters states "this first generation software proved the possible applications of technology (computer) based instruction” (p. 22). The 1978 explosion of moderately priced personal computers was the event that ushered in another generation of computer based music instruction. Advancement in hardware, such as digital-to-analog conversion boards, which found their way into keyboards/synthesizers, influenced the second generation of software programs (Peters, 1992). The Musical Instrument Digital Interface, also known as MIDI, was another technological breakthrough. MIDI and Compact Disc technologies have fostered new, improved software programs and have presented music educators with the challenge to research and design teaching strategies which use technology as an aid to develop music literacy, music understanding and sensitivity, and compositional skills (Berz \& Bowman, 1995).

The question today does not seem to be whether technological devices should be used in education, but rather, how they should be used (Wyman, 1966). Every teacher needs to make informed choices for every presentation. Wyman continues to state that the 
pace for the technological revolution in communication has been set by the audio media. We now have the ability to capture, store, and reproduce the sounds of our world with greater faithfulness than any other human experience. We can also have greater ease and economy. We can also alter, rearrange, combine and amplify sounds to produce any desire result. We can reproduce sounds for one or many, and in private or public and over any distance.

Williams (2004) has outlined a vision of Musical Futures of what new technology has the potential of dramatically changing the music classroom:

- $\quad$ Smaller and faster devices

- Wireless and mobile computing

- Digitization of media

- Changing music distribution

Computer and electronic devices are getting smaller and more ubiquitous. Today all media is being turned into digital bits. "What could be more exciting for a music teacher: the opportunity for our students, at any level of musical expertise, to be able to creatively manipulate digital sonic events.” He further recommends three key documents for classroom teachers as they integrate technology into their classroom. These resources begin with The MENC Opportunity to Learn (OTL) Standards (MENC, 1994). This is a set of music standards developed as part of a component of the national U.S. Goals 2000: Educate America Act (1994). There are nine OTL standards designed for children from pre-school to grade 12. Also included are the MENC OTL Standards for Music Technology (MENC, 1999). This document provides information on curriculum, staffing, professional development, materials/ software, equipment, and facilities for 
implementing music technology from pre-school through grades 12 . Lastly is the MENC Strategies for Teaching: Technology (Reese et al., 2001) which contains over 100 examples of real world applications creatively using technology for music teaching. The projects relate to the nine OTL standards and to grade levels of pre-K to grade 12 . The Technology Institute for Music Educators has further established seven distinct applications of technology which can serve to enhance learning each area of the national standards (Rudolph, 2004). These are:

1. Electronic Instruments

2. Music Notation Software

3. MIDI/digital audio sequencing

4. Instructional software

5. Telecommunications and the Internet

6. Multimedia and digital media

7. Information processing and lab management

The above categories can provide effective and exciting ways to augment and supplement the music curriculum. Music teachers should be most compelled to find ways to include technology in the classroom, instrumental, and choral curricula (Reese et al., 2001;

Rudolph, 2004).

Music Education and Technology

The present uses of computers and related technologies in music education, often limited to noncreative skill development, can expand to new horizons of musicality if they fulfill their potential of giving people direct access to creative decision making with sounds, storage and instant retrieval of those sounds, and 
devices to alter and refine the previous decisions: all conditions that would enable genuine creativity. (Riemer, 1989c. p. 71)

Music is an area where technology can be naturally integrated into the curriculum. Webster (1992) indicated that the use of technology in an art form such as music has always been accepted, and the use of electronic or digital technology is simply the next logical step in developing the art of music. The interaction between music and technology makes for an exciting learning experience for the students. Music as an art balances and enhances the science of technology. In addition, Riemer (1989a, 1989b) compares the importance of technology in music education to the invention of the phonograph. Leonhard (1999) reiterates the fact that developments in educational technology are the cause for a revolution in instruction and assessment in all areas of education, but particularly in the arts.

In 1985, the Apple Classrooms of Tomorrow (ACOT, 1996) research project involved teachers and students who were given access to cutting-edge technology tools whenever they needed them. This study was revisited by Johnson (2003) from a music teacher's point of view. His summation pointed out the benefits to using new technologies for music instruction. The ACOT reports (Dwyer et al., 1991) clearly showed that students were on task with subject matter more frequently and engaged subjects more deeply when technology tools were available. Technology provided more opportunities for students to produce tangible evidence of their learning. Teacher benefits included positive changes in the quality of their students learning, empowerment with a new sense of being able to deliver more relevant instruction, and a feeling of new enthusiasm for their teaching. Teachers were also more likely to share information with 
their peers. Teachers who integrated technology into their teaching eventually felt more confident that they could deliver good instruction to their students and more capable to effectively deal with the demands of their profession (Dwyer et al., 1991; Johnson, 2003). The root issue for educators is how to blend America's tradition of schooling with the capabilities of America's information and communications technologies (Mecklenburger, 1986).

Sarath (1995) affirms the necessity for music educators to utilize technology and urges a paradigm shift to use technology to provide integrated and comprehensive experiences in the classroom. There are many advantages to incorporating technology into the music curriculum (Moore, 1992). Technology helps educators teach existing courses more effectively. Mash (1997) supports this claim in his belief that technology makes it easier for teachers to create music for their students, which in turn allows students to become more actively involved in the learning process. Willman (1992) maintains that technology affects daily life, and similarly, music technology affects the way in which music is taught by students.

Alexander (1990) commented on the educational benefits that unfold when technology is implemented in music instruction. He maintained that when students are using MIDI-equipped instruments and recording technology, they have the ability to compose music at the same time they are studying it, enabling them to learn from their own creations. Beckstead (2001) supported the idea that MIDI technology equips the user with a variety of possibilities for creating music, possibilities that previously could not be imagined using only traditional, acoustic methods of creating and learning music. In the 
classroom, it is an invaluable tool for students; they can create, revise, and recreate their music at will.

Forest (1995) maintained that music educators must prepare students to be the musicians of the future. It is important that students be technologically literate in music as well as in other areas. Technology encourages active rather than passive learning when incorporated into existing curricula. Viable teaching strategies can be used in conjunction with technology to allow for increased learning achievement. The benefits of technology use in music include the effective demonstration of sound concepts, the student's heightened carefulness of execution when recording, student enthusiasm when using technology, and the ability to record and disseminate examples (Watson, 2005).

Contemporary computer technology has the potential to be an excellent resource for music educators working with students (McCord, 2001). It has been almost exclusively developed using MIDI or software synthesis. Only recently has it become practical to view this technology in a new light within the framework of its pedagogical applications by the music educator. Technology in the classroom now goes far beyond teachers using computers to assist in writing, grading, and creating lesson plans (Beckstead, 2001). A host of new and exciting technological alternatives has broadened the horizons of students across the country.

The Music Educators National Conference’s Research Agenda for Music Education (MENC, 1998) declares a need for studies related to music education for new, diverse, and under-served populations. It also asks researchers to study curricular innovation and challenges such as technology, music content, and assessment which are 
forcing teachers to rethink instructional strategies. Finally, it states that studies are needed to examine how advances in technology "enhance” existing music curricula.

As part of the response to research, The Music Educators National Conference (MENC) has established nine national content standards for teaching and learning music in American public schools. The standards apply to all students in grades K-12. Seven recommended curriculum content changes "for the coming century" include the supportive role of technology. The issue of technology in the music classroom is particularly addressed as one of the seven recommended changes. As part of its recommended curriculum changes, computers, synthesizers, CD-ROMs, and MIDI devices are seen as technology tools which expand music teaching and learning and which afford all students the advantage of personal involvement in creating, listening, and analyzing music (MENC 1994). Technology applications for the classroom which support each of the nine national content standards are suggested in Music Technology and the National Standards, authored by Rudoph (1997) of the Technology Institute for Music Educators (TI*ME).

The results of a classroom dynamics study conducted by Mandinach and Cline (1996) revealed fundamental changes in teaching and learning processes as a result of the implementation of a technology-based curriculum. They suggest that with the increased use of technology integrated into the curriculum, teachers need more opportunities to develop their skills as facilitators of student-centered learning. Upitis (1992) observed that within an integrated technology lesson, teachers found themselves in various roles as learned friend, co-composer, researchers, or participant. She suggests that technology in the classroom affords educators the opportunity to revise music teaching. 
Use of digital technology can lead, if effectively studied and implemented, to new ways of learning and understanding music as an art form and sound as a science. The student of music, no matter what their specialty, should have instruction in, and access to, digital technology which will allow them to engager in music according to their need and desires (Riemer, 1989b). Schooling will incorporate the need for many modes, and we will have to shift some of our traditional positions and practices. Riemer (1989a), calling for changes in performance and engagement in music by music educators, seeks to accomplish what the phonograph permitted, this being the direct experience of music limited only by a students level of literacy in its broadest sense. Brown (1997) encourages the change to digital technologies which permit expressions, reflections, and response to be sonic, visual, and textual in the one medium. Communicating the curricular message can be rich with meaning and examples. Music is abstract until it is sound. Digital technologies enable us to work with music as sound, text, score, video, and multimedia combinations of these. Changing technologies can change experiences which then expose new ways of thinking. Music educators' experience with music technology (regarding their knowledge and skills that can be applied to instruction) and the allocation of funding for technology both emerged as having prominent roles in the incorporation of music technology for instruction (Rhee, 2001).

Content is becoming more complex and what we know about how children learn is a major consideration. Discovery learning, problem solving, and divergent thinking is replacing rote learning and memorization (Webster, 2002). In the last ten years, music educators have used technology in a more constructionist context. Students construct their musical knowledge through experimentation while being guided by expert teachers 
(Kafai \& Resnick, 1996). Because of the availability of this technology, our school music curricula may need to be examined in light of the broadened and increased musiclistening habits of today's students (Wagner, 1988).

What is important for the teacher to know is that modes of cognition and perception are influenced not only by one's culture, but also by the communications media to which he is exposed. The arts, when viewed in the context of this new electronic environment, serve a unique and essential function. They are explorations in perceptionways of tuning up the senses. Students who are used to simultaneous bombardment of the eyes, ears, and mind need the arts to alert and reawaken their senses to new ways of perceiving what is familiar. In this sense, then, the arts-music among them can function compatibly in the electronic environment (Eickmann \& Fowler, 1971). Williams (2004) states that:

For the children and students we work with-at least in developed countries, the Internet, CD Music, video games, electronic music instruments, and MP3 music files are not technology. Our students have very different attitudes and views of technology than we do.

In the past 15 years the need for teacher training in technology across all subject areas has been increasingly discussed (Cuban, 2001; Jones, 2000). The increased need for technology training and the lack of study regarding the most effective instructional strategies in actual use by teachers continues to be an important issue (Bauer, Reese \& McAllister, 2003).

Contemporary music education programs are preparing tomorrows teachers (Estrella, 2004). Estrella cites the Berklee Self-Study for the department of Education 
which stated that:

Today’s technologies allow music students to participate actively in the learning process, gaining confidence while developing critical thinking and problem solving skills. Music teachers can use technology to create media rich learning experiences for their students while extending their reach beyond the classroom walls.

Many college and university programs anticipated the explosion of technology and responded by creating programs in which future music teachers could learn today's tools of the trade. As a result, many new music teachers expect to use a variety of technologies in their teaching (Estrella, 2004; Meltzer, 2001; Williams, 2004). New technological tools to create, teach, record, and manipulate music still amaze more mature music educators who began their careers using long-playing phonograph records and radios. Younger music educators tend to absorb these changes quickly. Technology has affected every music educator in one way or another and is likely to have even more influence in the future (Mark, 2002).

More and more non-music programs in colleges are eager to incorporate music technology into their professional disciplines, such as programs of media communication, education, or graphic design (Lin, 2005). They found that by utilizing music technology, they could easily catch up with musicians to produce music pieces or sound effects for their projects. Professionals in other areas more readily upgrade and integrate related knowledge and new technology into their curriculum. On the contrary, higher education/college music programs have music technology courses, but teachers usually neglect music technology as secondary positions, not seriously considering the 
possibilities of music technology integration into their teaching to enhance the students' music learning.

Administrative uses of computers and uses away from students continues to dominate the purposes for which teachers use technology (Reese \& Rimington, 2000). This research revealed trends which will help guide teachers toward educational use. These are:

1. The increasing importance of professional conferences to learn music technology

2. Continued interest by teachers in software applications for music education

3. Increasing use of technology to teach music listening

4. The general music classroom as the setting where students are most likely to use technology hands-on

Music teacher competency requirements can be gleamed from textbooks designed for music technology courses. Williams and Webster's (1999) textbook Experiencing Music Technology (2nd ed.) is a comprehensive guide to the history, hardware, and applications of music technology appropriate for all types of musicians. Another textbook more specific to music education technology is Rudolph’s (2004) Teaching Music with Technology. This text is designed to teach applications and strategies within the K-12 classroom. His book sets forth seven areas of competency in music education technology: electronic musical instruments, MIDI sequencing, music notation software, computerassisted instruction, multimedia and digitized media, Internet and communications, and information processing. Included are sample student activities that are designed to stimulate competency in each of the nine areas of the National Standards. A description 
of music technology skills needed by music educators can be inferred by the new MENC Opportunity-to-Learn Technology Standards (1999). Research on Music Teaching with Technology

Previous music technology surveys have focused on active music teachers (Hedden \& Gordon, 1998; Reese and Rimington, 2000; Stell, 1999; Taylor \& Deal, 1999). Study areas included the ways that technology is used by teachers and students, the extent of access to music technology, types of software and hardware used, and sources of funding.

These surveys indicated that only a minority of active music teachers have had formal training in the use of music technology, but most teachers are interested in learning more. A majority of music teachers uses technology, but only a minority use music software and an even smaller percentage use technology with their students (Meltzer, 2001). Meltzer included in his survey of college freshmen music majors regarding their high school music teachers analyzed how these teachers used music technology. These finding showed that $66 \%$ of the participants reported that the teachers used technology in the music classroom or music office. A high percentage (91\%) observed technology use for administrative purposes. Sixty-seven percent reported their teachers used a computer and/or MIDI synthesizer to develop teaching materials, record accompaniment tapes, or create other materials for classroom use. Generally, these teachers used technology more often for leading classroom activities than for preparing teaching materials or for students' hands-on use. Fifty-eight percent of the students reported that their teachers used technology to lead classroom activities once a week or more while $40 \%$ of the students reported that their teachers were providing opportunities 
for students hands-on use once a week or more. Thirty-nine percent of the students reported that their teachers were using computers to create teaching materials once a week or more. Meltzer observes that reports of frequency of use to create teaching materials might be low due to the fact that students were not present during their creation, yet the students need to be present when technology is used for leading classroom activities or for students' hand-on use. The ability and willingness of the respondents to use technology in the classroom to achieve specific instructional goals, in particular to implement music content standards of the National Standards for Arts Education, was most prevalent for educators with more than 16 years experience.

These findings concur with the earlier research done by Reese and Rimington (2000) and the more recent study by Taylor and Deal (1999). Both found that the most common use of technology applications was for administrative purposes. Taylor and Deal's research is a pilot study sponsored by MENC to create a national survey for collecting data on how music teachers are currently using technology and their attitudes towards the integration of technology into the K-12 music curriculum. The results of this study showed that $92 \%$ of the respondents used computers at school or home for school related activities with 55\% using computers for "music applications and also for applications related to music" (p. 25). Similar to the other studies mentioned, 29\% of these teachers used computer technology with students, with the highest use being music software for notation and for teaching music fundamentals. The music hardware was quite varied but still lacking when compared to the Opportunities to Learn_Standards for Music Technology (MENC, 1999). Only 35.7\% of the teachers had computers which contained features including a digital sound card, MIDI keyboard with synthesizer, 
keyboard controller, speaker, microphone, or "other”. These teachers had an overall positive attitude towards the continued integration of technology into their music curricula. Teachers responding to the Meltzer (2001) survey reported their use of technology applications first as overall or general use which was non-music applications, and second, as used specifically for music teaching and learning. Almost $25 \%$ used no technology applications for music teaching or learning.

Practicing Texas music educators teaching more than ten years reported the highest use of MIDI instruments and of digital recording (Ohlenbusch, 2001). Of all teachers at least $30-50 \%$ reported the use of MIDI and 10\% of all responses identified digital recording and CD creation and burning. Overall percentages of teacher use showed 40\% using MIDI and 10\% digital audio/recording.

Tredway (1994) surveyed a random sample of music teachers to determine the frequency of use of various equipment including audio, video, computer, and electronic musical instruments. The items most commonly used were identified along with how they were used. No data was collected concerning the level of previous instruction, classroom integration, or amount of usage.

Jassmann (2004), in a 2004 survey of South Dakota music educators, reported that $28 \%$ of music educators responded to using digital or MIDI technologies and that the primary student use was dominated by Computer Assisted Instruction. The type of software most used was notation

Yune (1998) surveyed secondary music teachers in Los Angeles and Orange County, California to identify types of computer applications being used to teach subjects 
such as music composition, audio skills, and music appreciation. Yune concluded that only a few music teachers were using music technology with their students.

In 1995, Sehmann and Hayes (1996) collected data concerning the status of technology usage by music teachers in Kentucky. They found that a large majority (79\%) of these teachers had access to some sort of technology somewhere in the school, but only a minority (33\%) used them during instructional time. It concluded that instructional use centered primarily on the use of the computer and that the low amount of instruction activity was a result of lack of access to music software. In their study, Sehmann and Hayes found a positive relationship between degrees held and the percentage of technology use of that teacher.

A similar, but more extensive, study was based on data collected from a random sample of Illinois K-12 schools (Reese, 2003). Data collected from 320 schools across the state covered such interrelated topics as perceived training needs of music educators in technology, ways music teachers and their students are using technology, the amount of time and location of access, use of software and hardware, and sources of funding. Data was analyzed by grade level, school size, and per-student expenditure. Data related to teachers were analyzed by grade level, program specialty, and years of experience. The results showed that a majority (83\%) of these music teachers had some kind of computer training, but only a minority of these teachers had training that focused on learning technology specific to music. The results showed that these music teachers learned the most about music technology in informal environments whether on their own or with colleagues. They were much less likely to have received specific training in such formal environments as a university course or school district sponsored workshop. A majority of 
music teachers surveyed (94\%) expressed the need for further training including the areas of the Internet and sequencing software.

Analysis of the use of technology by these music teachers showed that $76 \%$ used computers at school or at home for some reason related to music teaching with administrative uses outnumbering instructional ones. The most common instructional use included printing scores, creating arrangements, and composing. Only a few teachers (20\%) had their students use a computer as part of music class citing lack of training and limited access to technology. The most common music hardware, a MIDI keyboard, was present in 38\% of the schools. Notation, accompaniment, and sequencing software were the most common types of software being used.

A survey by Stell (1999) was completed with a sample of high school music teachers in Chicago Public Schools to determine the extent to which technology has been integrated into high school music teaching and to assess the impact it has had on the way music teachers teach. Her analysis showed that $39 \%$ of these teachers used computers as part of their teaching. The highest response was the use of computers as part of their teaching utilizing "music games" having the highest response with "drill and practice" software having the next highest. The study shows that there has been a positive impact on the teaching style and methods of the teachers who are integrating a variety of technology tools. For example, a majority of respondents said that the integration of technology has allowed them to spend less time lecturing during class, to spend more time with individual students, and to expect more creativity from their students. In a follow-up survey of music teachers in Illinois completed in 2002 (Reese \& Rimington, 2002), Reese found that $85 \%$ of responding teachers wanted to learn more 
about CAI, 75\% wanted to learn more about notation software, and 69\% wanted more information on how they could use the Internet to assist them. Evidence exists that Illinois schools and music educators are making steady progress in using music technology for teaching and learning.

K-12 music teacher surveys of this type help discover the types of technology available in schools and the technology used by practicing music educators. There have also been surveys that use freshmen music majors as their population. Analyses of these studies are valuable because they help determine attitudes and experiences with technology of future music teachers. Overall, these surveys of music teachers demonstrate the importance of assessing the current practices of music teachers who use technology. With respect to Metzler’s (2001) research, the studies provided a basis for establishing the value of survey questions about technology use. 


\section{Chapter 3}

\section{Method}

\section{Introduction}

The review of literature has shown the impact and potential that technology has had on music and music education. This wealth of new digital tools, when used appropriately, has the potential to support student engagement and enhancement of the musical experience than in any other time in the 100 year history of public school music education. Responding to this growth, The Technology Institute for Music Educators has divided technology into seven primary areas. The researcher has chosen to focus on the newest of these areas, digital audio technologies.

The purpose of this study was to identify which digital audio technologies are currently being used by WV music teachers, what influenced the technology use, what was the effect on learning, and what were the barriers to preventing more teachers from incorporating the technology. The objectives of the study are reflected in the following research questions:

RQ1: What are the demographic characteristics of WV public school music teachers who use digital audio technologies?

RQ2: What digital audio technologies are being used in music teaching environments? RQ3: What skills have WV public school music teachers acquired to utilize digital audio technologies for access, manipulation, dissemination, and use in teaching music education?

RQ4: What teaching decisions are made when using digital audio technologies and what impact do they have on student learning? 
RQ5: Has the use of digital audio technologies changed the teaching practices of WV public school music teachers?

\section{Participants}

Participants were full-time Certified Public School Music Teachers currently teaching music in Grades K-12 in the State of West Virginia ( $\mathrm{n}=$ approx. 500). Teachers were identified by records kept by the WV State Department of Education and verified through the eight Regional Education Service Agencies (RESA). As a result of interest in the data obtained by this study, the Arts Coordinator within the Office of Instruction of the West Virginia Department of Education provided the mailing addresses and school locations for the target study group. Solicitation for participation included both traditional mail and email requests and reminders.

Survey participants who were willing to participate in interviews and observations provided their name, school, school district, e-mail address, telephone number, and the most convenient days and times to be reached by telephone. These individuals were then selected for personal or telephone interviews based on criteria contained within their completed survey. The criteria are listed in the data collection process below.

By studying a purposeful sampling of teachers who self-reported a high use of digital audio technologies the skills, activities, teaching decisions, and influence of audio technologies emerged. It would not be beneficial to the purpose of this study to examine participants who had low familiarity or low self reported usage of digital audio technologies.

There are several different strategies for purposefully selecting information-rich examples to extrapolate data (Patton, 1990). Of the various types of purposeful sampling, 
criterion sampling provides the opportunity to examine a predetermined importance based on the criteria which is most appropriate to answer the study's research questions. Criteria for selecting participants for in-depth analysis were based on self-reported high use of digital audio technologies, RESA area, music education area of teaching, and, where possible, grade level.

\section{Data Sources}

Survey. A survey (Digital Audio Technologies for Teaching and Learning) was utilized to obtain a mixture of nominal and ordinal data (see Appendix A). Demographic information (nominal) consisted of 8 items from page one of the survey.

Interviews. Oral interviews followed a standardized open-ended question format and consisted of 10 questions (see Appendix B). Open-ended questions permitted teachers to respond in their own words while ensuring the ability to organize, compare, and summarize between groups (Patton, 1990).

Both the Digital Audio Technologies for Teaching and Learning survey and the Personal/Telephone Interview Protocol was pilot-tested. Pilot testing followed the method outlined by Dillman (2002) which included review by knowledgeable colleagues, evaluation of cognitive and motivational qualities and a pilot study with a small group. The pilot study was conducted in February 2008 to assist in the refinement of the written survey and interview protocol. Seven music teachers from an adjacent state participated in the pilot test which consisted of completing the survey and providing commentary as to clarity of instructions, clarity of questions, and degree of difficulty in completing the survey. The interview protocol was administered to three participants with feedback being provided. Revisions to the survey and interview protocol were based upon the 
recommendations of the participants and a mock analysis of data gathered. Changes included deletion of redundant items, clarification of some key terms, and format changes for legibility and ease of understanding.

Observations. Classroom observations were requested to observe teachers' use of digital audio technologies in context of teaching (see Appendix C). Four observations were conducted from the criterion based interview population. Notes from the visit and classroom observations were taken to describe the teachers' educational strategies, technology familiarity, and influence on successful teaching. These elements provided the basis for comparison analysis using the emerging themes gained in the individual interviews.

A visual summary of the data sources for each research question is depicted in Table 1.

\section{Table 1}

Summary of Sources and Analysis

\begin{tabular}{|l|l|l|}
\hline Research Question & Data Source(s) & $\begin{array}{l}\text { Analysis Procedures for each } \\
\text { Data Source }\end{array}$ \\
\hline $\begin{array}{l}\text { RQ1. What are the } \\
\text { demographic characteristics } \\
\text { of WV public school music } \\
\text { teachers who use digital } \\
\text { audio technologies? }\end{array}$ & Survey Questions 1-8 & $\begin{array}{l}\text { Frequency of Response: } \\
\bullet \quad \text { Experience } \\
\bullet \quad \text { Grade level } \\
\bullet \quad \text { Education }\end{array}$ \\
\hline $\begin{array}{l}\text { RQ2. What digital audio } \\
\text { technologies are being used } \\
\text { in music teaching } \\
\text { environments? }\end{array}$ & Survey Questions 9-12 & $\begin{array}{l}\text { Frequency of Response: } \\
\text { Use of Audio Formats } \\
\bullet \quad \begin{array}{l}\text { Use of devices } \\
\text { Use of processes } \\
\text { Use of software }\end{array}\end{array}$ \\
\hline
\end{tabular}


Summary of Sources and Analysis (Continued)

\begin{tabular}{|c|c|c|}
\hline Research Question & Data Source(s) & $\begin{array}{l}\text { Analysis Procedures for each } \\
\text { Data Source }\end{array}$ \\
\hline $\begin{array}{l}\text { RQ3. What skills have WV } \\
\text { public school music } \\
\text { teachers acquired to } \\
\text { utilize digital audio } \\
\text { technologies for access, } \\
\text { manipulation, dissemination, } \\
\text { and use in teaching music } \\
\text { education? }\end{array}$ & $\begin{array}{l}\text { Survey Question13 } \\
\text { Survey Question14 (a-g) } \\
\text { Interview Questions (1-3) }\end{array}$ & $\begin{array}{ll}\text { Frequency of Response: } \\
\text { - } & \text { Self reporting of skills } \\
\text { - } & \text { Level of skills } \\
\text { Guiding Themes: } \\
\text { - } & \text { Desire } \\
\text { - } & \text { Contributions } \\
\text { - } & \text { Current skills } \\
\text { - } & \text { Barriers } \\
\end{array}$ \\
\hline $\begin{array}{l}\text { RQ4. What teaching } \\
\text { decisions are made when } \\
\text { using digital audio } \\
\text { technologies and what } \\
\text { impact do they have on } \\
\text { student learning? }\end{array}$ & $\begin{array}{l}\text { Survey Question14 (h-q) } \\
\text { Interview Questions (4-7) } \\
\text { Observation Elements (a-d) }\end{array}$ & \begin{tabular}{|l} 
Frequency of Response: \\
- Reasons for use \\
- Designing lessons \\
Guiding Themes \\
- Desire \\
- Interactivity \\
- Assessment \\
- Teaching Strategy \\
\end{tabular} \\
\hline $\begin{array}{l}\text { RQ5. Has the use of digital } \\
\text { audio technologies changed } \\
\text { the teaching } \\
\text { practices of WV public } \\
\text { school music teachers? }\end{array}$ & $\begin{array}{l}\text { Interview Questions (4-10) } \\
\text { Observation Elements (e-g) }\end{array}$ & $\begin{array}{ll}\text { Emerging Themes } \\
\text { - } & \text { Influence on Teaching } \\
\text { - } & \text { Success/Failure } \\
- & \text { View of Content }\end{array}$ \\
\hline
\end{tabular}

\section{Data Collection}

Survey. Upon receiving exemption from West Virginia University's Board of

Human Subjects to conduct this study, the self-reporting survey instrument was placed on the World Wide Web. This exemption is included in Appendix D. Invitations to participate were disseminated via email using the addresses obtained from the eight RESAs. All current music teachers were provided advanced notice and introductory information. RESA areas with a significant lack of respondents received follow-up communication via phone, email, and letter. There were 103 participants in the survey 
with six completed surveys being rejected as not usable as greater than $50 \%$ of the answers were not completed. See Appendix A for survey questions.

Interviews. Upon completion of the self-reporting survey deadline, 24 participants were carefully selected based on the criterion sampling strategy (three teachers for each of eight RESA districts). Participants were selected using the following criteria in order of importance:

- Willingness to be interviewed and potential for observation of lessons

- Aggregate score of skills summary (Survey Question 13) [24]

- $\quad$ RESA served (Participant Code) [three per area]

- Grade and Area of Instruction (Survey Questions 1 and 2) [eight general, eight vocal, eight instrumental]

Personal interviews were conducted at the time and location chosen by the identified participants. The interviews were recorded for later transcription and coding. During the interview the researcher took notes and observed sample uses of digital audio technologies when demonstrated by the participant. See Appendix B for the interview protocol and questions.

Observations. Site-visit and classroom observations were conducted, where possible, on the same day of the interview meeting. Field notes were also taken during and after the observations. See Appendix C for the observation elements.

\section{Data Organization and Analysis}

Survey. Data collected from the Digital Audio Technologies for Teaching and Learning instrument is divided into four small sections, including (1) demographic information about the teacher, (2) digital audio technology use, (3) digital audio 
technology skills, and (4) teaching decisions. Data returned from the questionnaires was entered into an Excel table to be analyzed using the Statistical Package for the Social Sciences (SPSS).

The data from the survey was ordinal and nominal data which is displayed as frequencies and percentages in both narrative and table format. A mean was calculated and applied to each summary to provide information on the average level of usage, specific technology usage, skill level, and prevalent teaching decisions used. The summary and demographic information answers RQ1 and RQ2 while providing some descriptive statistics in support of answering RQ3 and RQ 4.

Interviews. Upon the completion of all interviews, case study data of individual teachers was analyzed using transcribed tape recordings and written notes. The initial analysis of this data identified emerging themes and was appropriately coded. Coded themes were clustered in terms of similarity allowing for meaningful categorization of data and the detection of relationships between the various pieces (Miles \& Huberman, 1994). Once identified, a matrix of significant themes and patterns was created permitting classification within the categorizations necessary to answer the RQs. To answer RQ3 the emerging themes were guided by the broader areas of desire, contributions, barriers, and current skills. To answer RQ4 the emerging themes were guided by the broader areas of desire, interactivity, assessment, teaching strategy, and technology choice. To answer RQ5 the emerging themes were guided by the broader areas of influence on teaching, success or failure, and the perception of content.

Observations. Classroom observations of the interview/observation participants were coded by common or recurring themes, patterns, and categories emerging from the 
notes taken. This consisted of accurate descriptions of the classroom activities, instructional practices, and teacher participants and is presented as part of the data contributing to answer RQ4 and RQ5. Additionally, observations became a part of an analysis using triangulation to answer RQ4. This was achieved by verifying the consistency of findings generated through the survey, interviews, and observations.

\section{Limitations}

The survey was the primary tool for collecting data and as a basis for collecting and interpreting data obtained by the interviews and observations. The survey is limited by the reliability of self-reported data. The reliance on the self-reporting may lower the validity of the survey results. The interviews and observations were limited by the number and format of interview and observation opportunities and the amount of time spent during the observations. Multiple data sources in the method design may minimize errors that may arise from a single technique. The criteria sampling of participants provides a limited number of cases to be studied.

The teachers surveyed were limited to those currently teaching full-time as a music specialist in Grades K-12 within a West Virginia Public School. Only teachers licensed by the State of West Virginia and holding a valid Music Teaching Certificate for the Academic Year of 2007-2008 were included in the survey and subsequent interviews. The study is not intended to represent alternative licensure or music content taught by other classroom teachers in West Virginia. Surveys of teachers in other states with different levels of access to technology or various levels of technical support might produce different results. 


\section{Chapter 4}

\section{Findings}

The purpose of this study was to identify which digital audio technologies are currently being used by WV music teachers, what influenced the technology use, what was the effect on learning, and what were the barriers to preventing more teachers from incorporating the technology. This study attempted to answer following research questions:

RQ1: What are the demographic characteristics of WV public school music teachers who use digital audio technologies?

RQ2: What digital audio technologies are being used in music teaching environments?

RQ3: What skills have WV Public School Music teachers acquired to utilize digital audio technologies for access, manipulation, dissemination, and use in teaching music education?

RQ4: What teaching decisions are made when using digital audio technologies and what impact do they have on student learning?

RQ5: Has the use of digital audio technologies changed the teaching practices of WV public school music teachers?

Three methods of data collection were utilized, including a survey instrument, interviews, and classroom observations. This chapter will present the data as collected from the survey instrument, interviews, and observations. Interview and observation participants are presented as individual cases or recurring themes, patterns, and categories, proceeded by a discussion of data. These data sources were used in combination to provide verifiable data and a method that would effectively answer the 
research questions listed above.

The Survey Instrument

The purpose of the survey, Digital Audio Technologies for Teaching and

Learning (Appendix A), was to gain a better understanding of how WV Music Educators used digital audio technologies in their classroom and their level of experience with the technology. The survey included sections addressing hardware, software, skill, and teaching decisions. Data collected from the Digital Audio Technologies for Teaching and Learning instrument was divided into four small sections, including (1) demographic information about the teacher, (2) digital audio technology use, (3) digital audio technology skills, and (4) teaching decisions.

Research Question 1: What are the demographic characteristics of WV public school music teachers who use digital audio technologies?

Demographic information. Demographics were studied to provide a profile of the participants and to understand the population involved in the study. Demographic data were collected to indicate the level of expertise of the population involved such as the grade level of students taught, number of years teaching, amount of education and participant's general geographic location within the state. This data was used to answer RQ1. As indicated in Table 2, over 50\% of the participants have been teaching 10 years or more with slightly greater representation from those who teach in elementary or middle schools. 84 percent taught some form of general music, greater than $50 \%$ taught choral or instrumental music, and only $2 \%$ reported teaching in the areas of strings. Each RESA service area had participants with the lowest amount of respondents representing $4 \%$ of the population. 43 percent of participants had some form of additional study 
beyond the Bachelors degree.

Table 2

Demographic Profile of Participants ( $N=93)$

\begin{tabular}{|c|c|c|c|}
\hline & Demographics & $n$ & $\%$ \\
\hline \multirow[t]{3}{*}{ Grade Levels: } & K-5 or K-6: & 49 & 53.0 \\
\hline & Middle or Junior: & 45 & 48.0 \\
\hline & High School: & 27 & 29.0 \\
\hline \multirow{4}{*}{$\begin{array}{l}\text { Areas of Instruction: } \\
\text { (92 Responders) }\end{array}$} & General Music: & 77 & 84.0 \\
\hline & Choral Music: & 59 & 64.0 \\
\hline & Instrumental Music: & 53 & 58.0 \\
\hline & Strings: & 2 & 2.0 \\
\hline \multirow[t]{2}{*}{ Gender: } & Male: & 56 & 60.0 \\
\hline & Female: & 37 & 40.0 \\
\hline \multirow[t]{4}{*}{ Years Teaching: } & $1-5$ & 18 & 19.0 \\
\hline & $6-10$ & 11 & 12.0 \\
\hline & $10-20$ & 25 & 27.0 \\
\hline & $>20$ & 20 & 42.0 \\
\hline \multirow[t]{4}{*}{ Highest Degree: } & Bachelors: & 53 & 57.0 \\
\hline & Masters: & 4 & 4.0 \\
\hline & Masters Plus: & 35 & 38.0 \\
\hline & Doctorate: & 1 & 1.0 \\
\hline
\end{tabular}


Demographic Profile of Participants (N=93) (Continued)

\begin{tabular}{lllc}
\hline & Demographics & $n$ & $\%$ \\
\hline $\begin{array}{l}\text { RESA Service Area: } \\
\text { (74 respondents) }\end{array}$ & RESA I: & 8 & 11.0 \\
& RESA II: & 4 & 5.0 \\
& RESA III: & 14 & 19.0 \\
& RESA IV: & 7 & 9.0 \\
& RESA V: & 7 & 9.0 \\
& RESA VI: & 21 & 28.0 \\
& RESA VII: & 10 & 14.0 \\
& RESA VIII & 3 & 4.0 \\
\hline Teaching Environment & 1 School: & 57 & 61.0 \\
& Multiple Schools & 36 & 39.0 \\
\hline
\end{tabular}

Research Question 2: What digital audio technologies are being used in music teaching environments?

To Answer RQ 2 this section of the survey was divided into four sections, including (1) use of audio formats, (2) use of digital audio devices, (3) use of digital audio processes and activities, and (4) use of digital audio software. A Likert scale measures the extent to which respondents agreed or disagreed with the questions was utilized. The scale was 1 to 5 with the answer criteria being $1=$ not at all, $2=$ once a month or less, $3=$ once a week, $4=$ several times a week, and 5 = every day.

Use of audio formats. Audio formats used by music teachers were studied to determine the adoption or rejection of specific formats and the utilization of the primary formats most 
commonly available for classroom use. This data was used to assist in answering RQ2. As indicated in Table 3, the most frequently used format is the Compact Disc with 86\% reporting use once a week or greater. This is followed by MP3s with just under 50\% reflecting the same frequency. A large number from the population reported no use of Digital Audio Tape (83\%) followed by $78 \%$ responding that they never used records or Internet radio. The analog formats least used were records and cassettes. Reported data of use once a month or less, or never used was $98 \%$ for records and $89 \%$ for cassettes. The Mean of all ratings was 2.0 .

Table 3

Use of Audio Formats $(N=93)$

\begin{tabular}{|c|c|c|c|c|c|c|c|c|}
\hline & 1 & 2 & 3 & 4 & 5 & $\mathrm{M}$ & Mdn & Responders \\
\hline Records & $\begin{array}{l}78 \% \\
(70)\end{array}$ & $\begin{array}{l}20 \% \\
(18)\end{array}$ & $\begin{array}{l}0 \% \\
(0)\end{array}$ & $\begin{array}{l}1 \% \\
(1)\end{array}$ & $\begin{array}{l}1 \% \\
(1)\end{array}$ & 1.3 & 1.0 & 90 \\
\hline Cassettes & $\begin{array}{l}40 \% \\
(36)\end{array}$ & $\begin{array}{l}49 \% \\
(44)\end{array}$ & $\begin{array}{l}8 \% \\
(7)\end{array}$ & $\begin{array}{l}3 \% \\
(3)\end{array}$ & $\begin{array}{l}0 \% \\
(0)\end{array}$ & 1.7 & 2.0 & 90 \\
\hline CD’s & $\begin{array}{l}2 \% \\
(2)\end{array}$ & $\begin{array}{l}12 \% \\
(11)\end{array}$ & $\begin{array}{l}13 \% \\
(12)\end{array}$ & $\begin{array}{l}27 \% \\
(25)\end{array}$ & $\begin{array}{l}46 \% \\
(43)\end{array}$ & 4.0 & 4.0 & 93 \\
\hline MP3 & $\begin{array}{c}39 \% \\
(34\end{array}$ & $\begin{array}{l}15 \% \\
(13)\end{array}$ & $\begin{array}{l}16 \% \\
(14)\end{array}$ & $\begin{array}{l}18 \% \\
(16)\end{array}$ & $\begin{array}{l}13 \% \\
(11)\end{array}$ & 2.5 & 2.0 & 88 \\
\hline DAT & $\begin{array}{l}83 \% \\
(72)\end{array}$ & $\begin{array}{c}10 \% \\
(9)\end{array}$ & $\begin{array}{l}6 \% \\
(5)\end{array}$ & $\begin{array}{l}1 \% \\
(1)\end{array}$ & $\begin{array}{l}0 \% \\
(0)\end{array}$ & 1.2 & 1.0 & 87 \\
\hline $\begin{array}{l}\text { Internet } \\
\text { Streaming }\end{array}$ & $\begin{array}{l}52 \% \\
(46)\end{array}$ & $\begin{array}{l}26 \% \\
(23)\end{array}$ & $\begin{array}{l}6 \% \\
(5)\end{array}$ & $\begin{array}{l}7 \% \\
(6)\end{array}$ & $\begin{array}{l}9 \% \\
(8)\end{array}$ & 1.9 & 1.0 & 88 \\
\hline $\begin{array}{c}\text { Internet } \\
\text { Radio }\end{array}$ & $\begin{array}{l}78 \% \\
(69)\end{array}$ & $\begin{array}{l}11 \% \\
(10)\end{array}$ & $\begin{array}{l}5 \% \\
(4)\end{array}$ & $\begin{array}{l}3 \% \\
(3)\end{array}$ & $\begin{array}{l}2 \% \\
(2)\end{array}$ & 1.4 & 1.0 & 88 \\
\hline
\end{tabular}

When viewed in Figure 2, which examines the oldest technologies to the newest, the data clearly reflects the migration away from analog formats towards those which are digital in 
nature. This data compares responses reporting having never using a specific format and those who use certain formats daily. The analog formats of records and cassettes have yielded to the digital formats of compact discs and MP3 digital audio files The use of Internet Streaming as an audio format parallels the lack of adoption and use of the digital audio tape (DAT).

Figure 2. Percentage of Respondents Who Use Daily or Never Use an Audio Format.

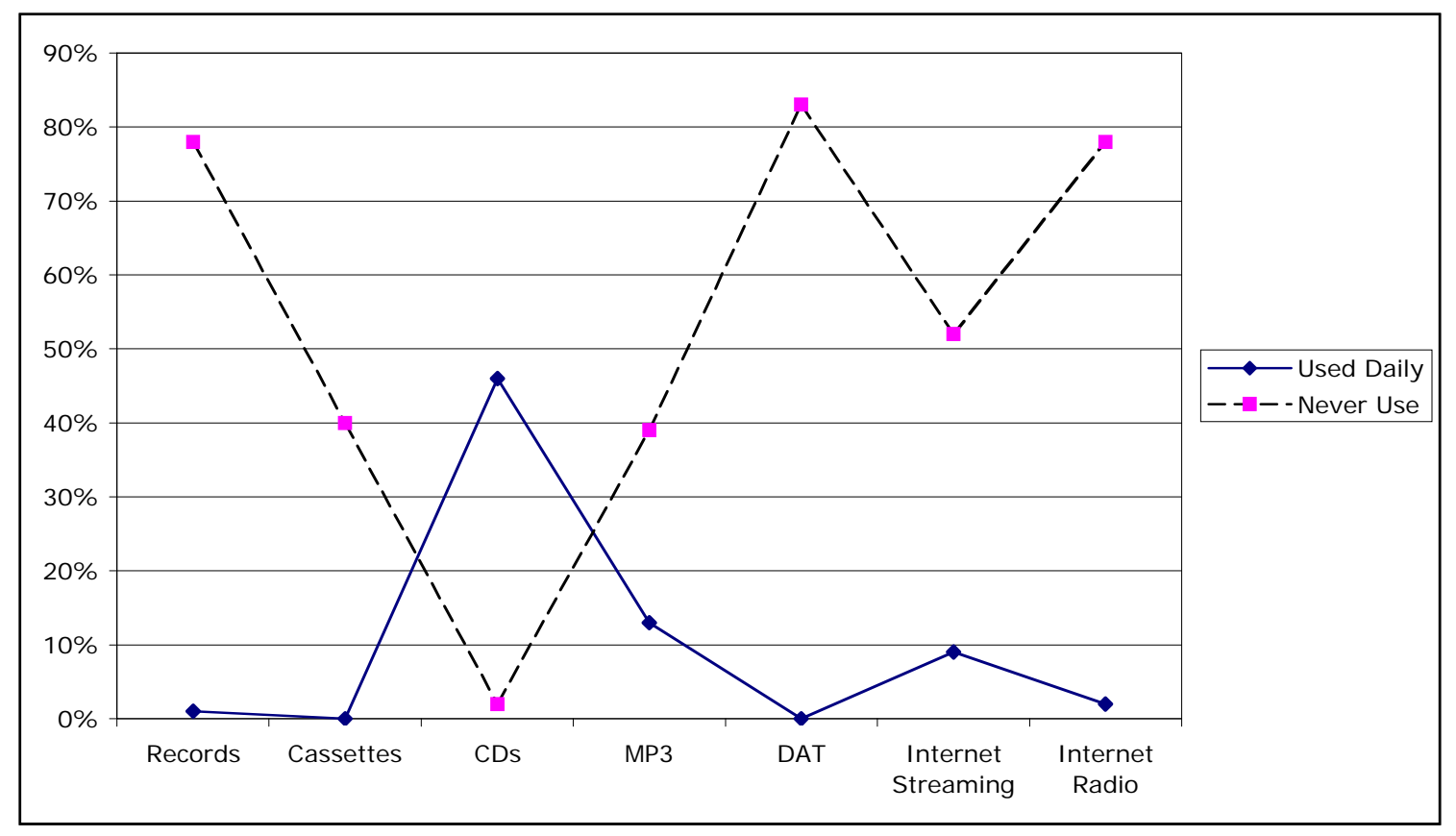

Digital audio devices. The use of Digital Audio Devices was studied to determine what devices were most used in music teaching. By analyzing this data the relevance of such devices can be determined. This information can be categorized into four sub groups, which include stand alone musical instruments, computer interfaced hardware, stand alone duplication equipment, and audio playback/source devices.

As indicated in Table 4, less than half (40\%) of the teachers use an electronic keyboard with any frequency. A more significant lack of usage was reported when the keyboard had MIDI capabilities. Teachers using MIDI keyboards once a month or less, or never using such a device was $62 \%$. 
Computer use for music teaching rated as the most used audio application. $71 \%$ reported using the computer in their instruction several times a week or daily. An additional 5\% used the computer once a week or once a month. Once-a-month or less, and never used answers represented $24 \%$.

Audio interfaces were not being utilized based on the responses of $75 \%$ or greater, rarely, or never using them in classroom instruction. The most favored interface was wired playback with at least weekly use and greater being $44 \%$ of the answers.

Duplication devices included in the survey were not a significant part of music teaching. Only 38\% of the teachers reported using a CD burner with any frequency. These numbers decrease as DVD Burners are examined with only 13\% using them actively. Digital Audio Tape recording is rare with $91 \%$ never using such a device.

Very little use of sound modules was reported with 11\% showing significant use in instruction. Less than $40 \%$ of the music teachers used an iPod or other MP3 player in their classroom on a consistent basis. The Mean of all answers was 2.2.

Table 4

Use of Digital Audio Devices (N=93)

\begin{tabular}{|c|c|c|c|c|c|c|c|c|}
\hline & 1 & 2 & 3 & 4 & 5 & $\mathrm{M}$ & Mdn & Responders \\
\hline $\begin{array}{l}\text { Electronic } \\
\text { Keyboard }\end{array}$ & $\begin{array}{l}28 \% \\
(26)\end{array}$ & $\begin{array}{l}12 \% \\
(11)\end{array}$ & $\begin{array}{l}4 \% \\
(4)\end{array}$ & $\begin{array}{l}21 \% \\
(19)\end{array}$ & $\begin{array}{l}35 \% \\
(32)\end{array}$ & 3.2 & 4.0 & 92 \\
\hline $\begin{array}{l}\text { Keyboard } \\
\text { w/MIDI }\end{array}$ & $\begin{array}{l}53 \% \\
(47)\end{array}$ & $\begin{array}{l}9 \% \\
(8)\end{array}$ & $\begin{array}{l}4 \% \\
(4)\end{array}$ & $\begin{array}{l}11 \% \\
(10)\end{array}$ & $\begin{array}{l}22 \% \\
(20)\end{array}$ & 2.4 & 1.0 & 89 \\
\hline
\end{tabular}

(table continues) 
Use of Digital Audio Devices (N=93) (Continued)

\begin{tabular}{|c|c|c|c|c|c|c|c|c|}
\hline & 1 & 2 & 3 & 4 & 5 & M & Mdn & Responders \\
\hline Computer & $\begin{array}{l}12 \% \\
(11)\end{array}$ & $\begin{array}{l}12 \% \\
(11)\end{array}$ & $\begin{array}{l}5 \% \\
(5)\end{array}$ & $\begin{array}{l}13 \% \\
(12)\end{array}$ & $\begin{array}{l}58 \% \\
(54)\end{array}$ & 3.9 & 5.0 & 93 \\
\hline $\begin{array}{c}\text { Internal } \\
\text { Interface }\end{array}$ & $\begin{array}{l}60 \% \\
(53)\end{array}$ & $\begin{array}{l}15 \% \\
(13)\end{array}$ & $\begin{array}{l}7 \% \\
(6)\end{array}$ & $\begin{array}{c}10 \% \\
(9)\end{array}$ & $\begin{array}{l}9 \% \\
(8)\end{array}$ & 1.9 & 1.0 & 89 \\
\hline $\begin{array}{l}\text { External } \\
\text { Interface }\end{array}$ & $\begin{array}{l}63 \% \\
(55)\end{array}$ & $\begin{array}{l}13 \% \\
(11)\end{array}$ & $\begin{array}{l}8 \% \\
(7)\end{array}$ & $\begin{array}{l}5 \% \\
(4)\end{array}$ & $\begin{array}{l}14 \% \\
(11)\end{array}$ & 1.9 & 1.0 & 88 \\
\hline $\begin{array}{l}\text { Wireless } \\
\text { Playback }\end{array}$ & $\begin{array}{l}75 \% \\
(69)\end{array}$ & $\begin{array}{l}12 \% \\
(11)\end{array}$ & $\begin{array}{l}3 \% \\
(3)\end{array}$ & $\begin{array}{l}5 \% \\
(5)\end{array}$ & $\begin{array}{l}4 \% \\
(4)\end{array}$ & 1.5 & 1.0 & 92 \\
\hline $\begin{array}{c}\text { Wired } \\
\text { Playback }\end{array}$ & $\begin{array}{l}50 \% \\
(53)\end{array}$ & $\begin{array}{l}7 \% \\
(6)\end{array}$ & $\begin{array}{l}8 \% \\
(7)\end{array}$ & $\begin{array}{l}12 \% \\
(11)\end{array}$ & $\begin{array}{l}14 \% \\
(13)\end{array}$ & 2.1 & 1.0 & 90 \\
\hline CD Burner & $\begin{array}{l}21 \% \\
(19)\end{array}$ & $\begin{array}{l}41 \% \\
(37)\end{array}$ & $\begin{array}{l}25 \% \\
(23)\end{array}$ & $\begin{array}{l}8 \% \\
(7)\end{array}$ & $\begin{array}{l}5 \% \\
\text { (5) }\end{array}$ & 2.3 & 2.0 & 91 \\
\hline $\begin{array}{l}\text { DVD } \\
\text { Burner }\end{array}$ & $\begin{array}{l}68 \% \\
(61)\end{array}$ & $\begin{array}{l}19 \% \\
(17)\end{array}$ & $\begin{array}{l}9 \% \\
(8)\end{array}$ & $\begin{array}{l}2 \% \\
(2)\end{array}$ & $\begin{array}{l}2 \% \\
(2)\end{array}$ & 1.5 & 1.0 & 90 \\
\hline $\begin{array}{c}\text { DAT } \\
\text { Recorder }\end{array}$ & $\begin{array}{l}91 \% \\
(81)\end{array}$ & $\begin{array}{l}7 \% \\
(6)\end{array}$ & $\begin{array}{l}1 \% \\
(1)\end{array}$ & $\begin{array}{l}1 \% \\
(1)\end{array}$ & $\begin{array}{l}0 \% \\
(0)\end{array}$ & 1.1 & 1.0 & 89 \\
\hline $\begin{array}{l}\text { Sound } \\
\text { Modules }\end{array}$ & $\begin{array}{c}73 \% \\
67\end{array}$ & $\begin{array}{l}16 \% \\
(15)\end{array}$ & $\begin{array}{l}8 \% \\
(7)\end{array}$ & $\begin{array}{l}0 \% \\
(0)\end{array}$ & $\begin{array}{l}3 \% \\
(3)\end{array}$ & 1.4 & 1.0 & 92 \\
\hline $\begin{array}{l}\text { iPod or } \\
\text { other MP3 }\end{array}$ & $\begin{array}{l}52 \% \\
(47)\end{array}$ & $\begin{array}{l}11 \% \\
(10)\end{array}$ & $\begin{array}{l}12 \% \\
(11)\end{array}$ & $\begin{array}{l}13 \% \\
(12)\end{array}$ & $\begin{array}{l}12 \% \\
(11)\end{array}$ & 2.2 & 1.0 & 91 \\
\hline
\end{tabular}

Digital audio processes and activities. The use of Digital Audio Processes and Activities was studied to determine what processes music teachers are using to utilize digital audio technologies in their teaching. These questions involved either the creation or dissemination of audio material, the purchase and use of CD-ROMs and digital files, and the sources where digital formats might be obtained. To more easily view the data, figures have been created using the 
above question categories. A reporting of the data surveying processes and activities is included in Table 5.

As indicated in Figure 3, very few teachers created their own MIDI files with 64\% having never done so. Even those who have created files rarely use the Internet for their dissemination. Similarly, audio files were never disseminated $59 \%$ of the time. Nearly three fourths of the teachers (71\%) have created a student CD within the academic year. When CDs were created, classroom use was the predominant reason with a 73\% response rate towards such an endeavor. Figure 3. Creation and Dissemination of Audio Material.

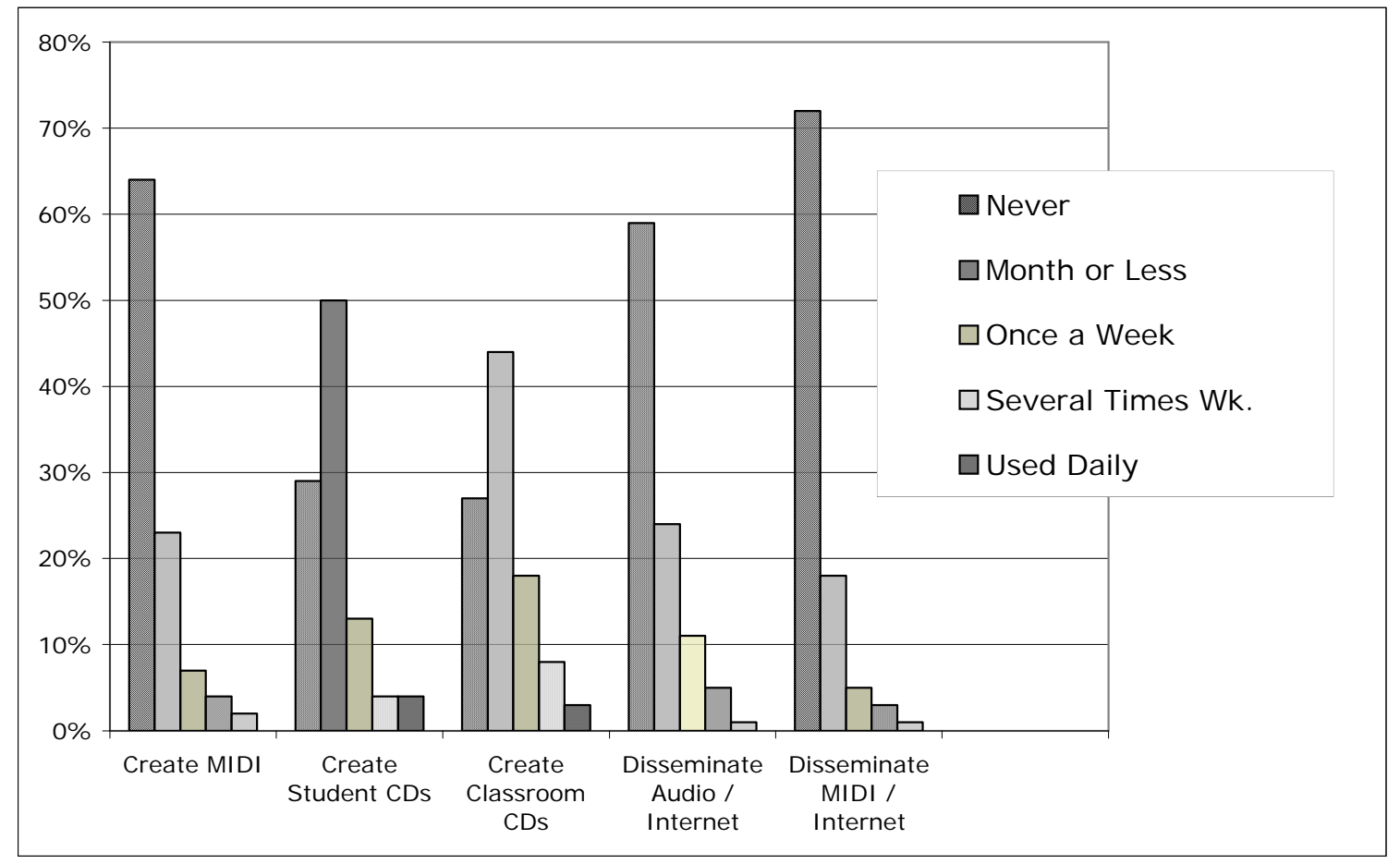

Figure 4 visualizes the purchase and use of CD-ROM, audio files, and MIDI files. Respondents indicating once-a-month or less, or never used, $83 \%, 89 \%$, and $79 \%$ of the time, respectively. A small percentage of the music teachers used the file processes weekly or greater with the preferred use being purchased compact discs. 
Figure 4. Purchase and Use of CD-ROM, Audio Files, and MIDI Files.

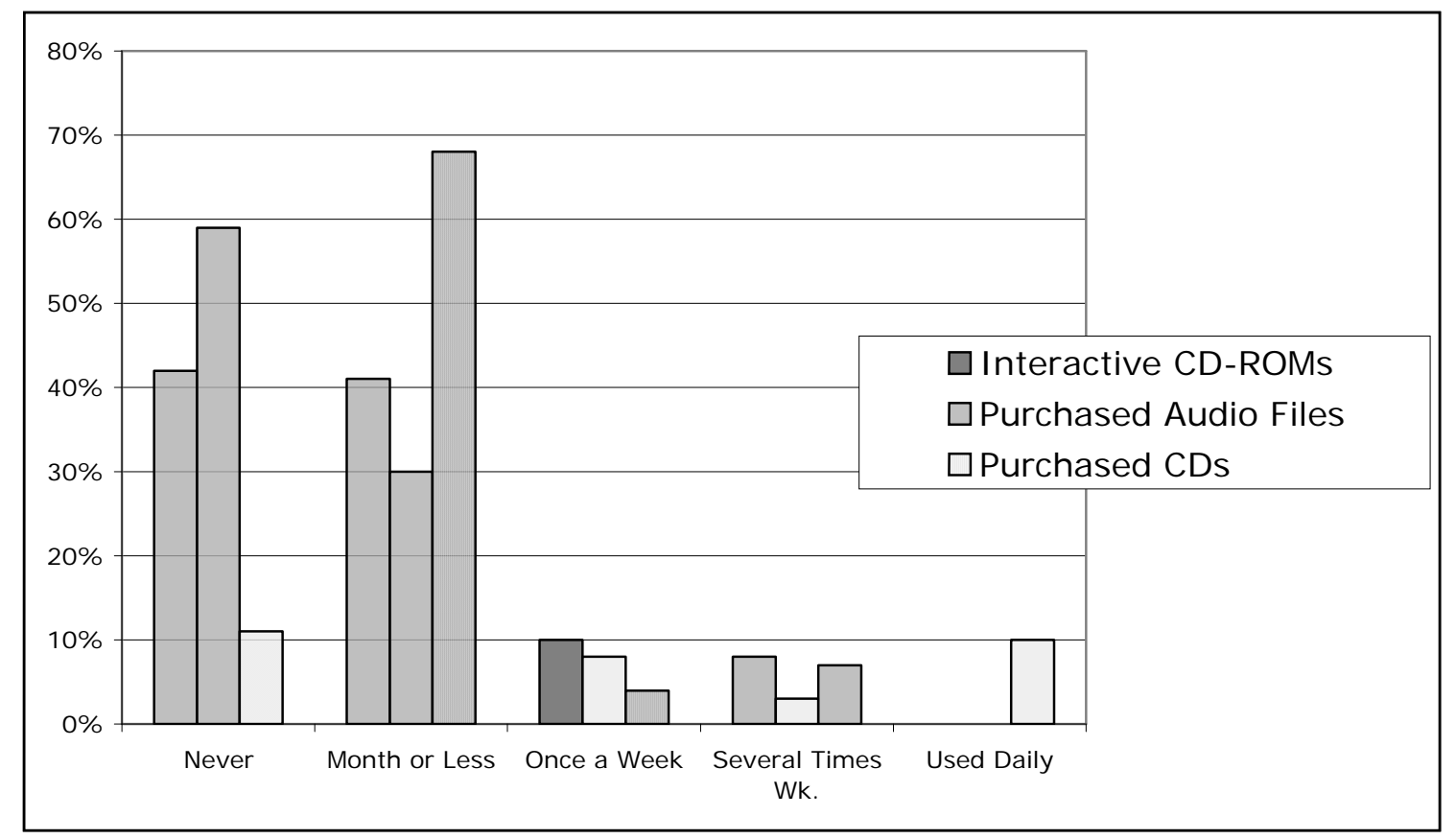

Figure 5 clearly indicates that a majority of music teachers do not obtain their audio material from commercial music ventures, public domain sources, or from peer to peer file sharing networks. The leading source of audio materials for teaching was from “others” with $63 \%$ having reported that, regardless of frequency, they had obtained some audio material. Nearly half (48\%) had utilized iTunes or another commercial source at some period within their teaching. Similarly, 45\% reported having obtained public domain files, though not very frequently. 
Figure 5. Sources of Audio Files

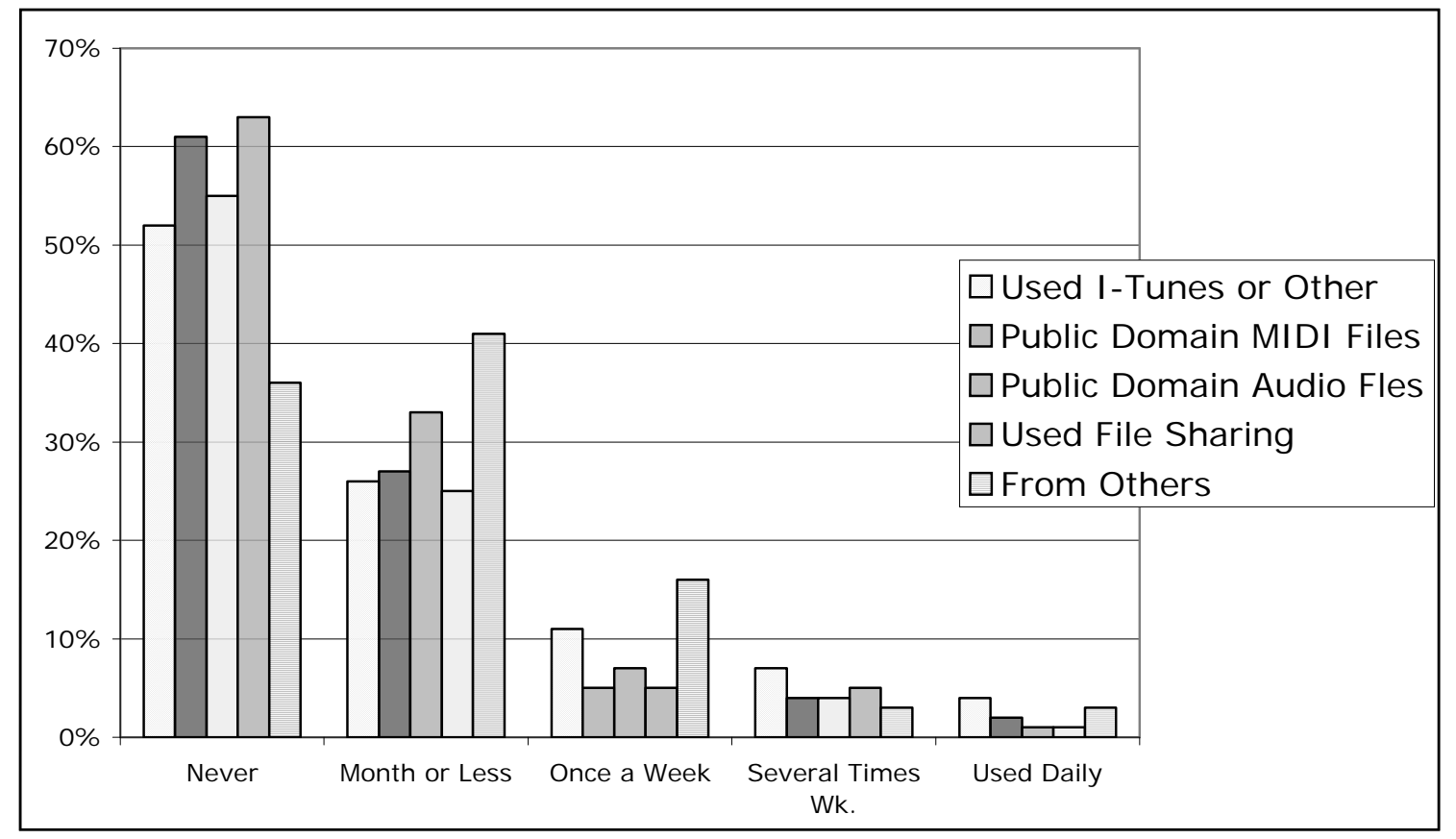

Table 5 represents all of the data obtained in this category. The mean of all answers was

1.8. Compact disc usage ranked the highest in all with highest mean scores being between 2.0 and 2.3. A majority of teachers do not use the Internet to disseminate material, do not create MIDI files, or use purchased and public domain files in their teaching.

Table 5

Use of Digital Audio Processes and Activities (N=93)

\begin{tabular}{ccccccccc}
\hline & 1 & 2 & 3 & 4 & 5 & M & Mdn & Responders \\
\hline $\begin{array}{c}\text { Create a } \\
\text { MIDI File }\end{array}$ & $\begin{array}{c}64 \% \\
(59)\end{array}$ & $\begin{array}{c}23 \% \\
(21)\end{array}$ & $\begin{array}{c}7 \% \\
(6)\end{array}$ & $\begin{array}{c}4 \% \\
(4)\end{array}$ & $\begin{array}{c}2 \% \\
(2)\end{array}$ & 1.5 & 1.0 & 92 \\
\hline Interactive & $\begin{array}{c}4 \% \\
\text { CD-ROMs }\end{array}$ & $\begin{array}{c}41 \% \\
(39)\end{array}$ & $\begin{array}{c}10 \% \\
(9)\end{array}$ & $\begin{array}{c}8 \% \\
(7)\end{array}$ & $\begin{array}{c}0 \% \\
(0)\end{array}$ & 1.8 & 2.0 & 93 \\
\hline
\end{tabular}

(table continues) 
Use of Digital Audio Processes and Activities (N=93) (Continued)

\begin{tabular}{|c|c|c|c|c|c|c|c|c|}
\hline & 1 & 2 & 3 & 4 & 5 & $\mathrm{M}$ & Mdn & Responders \\
\hline $\begin{array}{c}\text { Disseminate } \\
\text { Audio } \\
\text { through } \\
\text { Internet }\end{array}$ & $\begin{array}{l}59 \% \\
(55)\end{array}$ & $\begin{array}{l}24 \% \\
(22)\end{array}$ & $\begin{array}{l}11 \% \\
(10)\end{array}$ & $\begin{array}{l}5 \% \\
(5)\end{array}$ & $\begin{array}{l}1 \% \\
(1)\end{array}$ & 1.6 & 1.0 & 93 \\
\hline $\begin{array}{c}\text { Disseminate } \\
\text { MIDI } \\
\text { through } \\
\text { Internet }\end{array}$ & $\begin{array}{l}72 \% \\
(66)\end{array}$ & $\begin{array}{l}18 \% \\
(17)\end{array}$ & $\begin{array}{l}5 \% \\
(5)\end{array}$ & $\begin{array}{l}3 \% \\
(3)\end{array}$ & $\begin{array}{l}1 \% \\
(1)\end{array}$ & 1.4 & 1.0 & 92 \\
\hline $\begin{array}{l}\text { Purchased } \\
\text { Audio Files }\end{array}$ & $\begin{array}{l}59 \% \\
(54)\end{array}$ & $\begin{array}{l}30 \% \\
(27)\end{array}$ & $\begin{array}{l}8 \% \\
(7)\end{array}$ & $\begin{array}{l}3 \% \\
(3)\end{array}$ & $\begin{array}{l}0 \% \\
(0)\end{array}$ & 1.5 & 1.0 & 91 \\
\hline $\begin{array}{l}\text { Purchased } \\
\text { CDs }\end{array}$ & $\begin{array}{l}11 \% \\
(10)\end{array}$ & $\begin{array}{l}68 \% \\
(63)\end{array}$ & $\begin{array}{l}4 \% \\
(4)\end{array}$ & $\begin{array}{l}7 \% \\
(6)\end{array}$ & $\begin{array}{l}10 \% \\
(9)\end{array}$ & 2.3 & 2.0 & 92 \\
\hline $\begin{array}{l}\text { Created CDs } \\
\text { for students }\end{array}$ & $\begin{array}{l}29 \% \\
(26)\end{array}$ & $\begin{array}{l}50 \% \\
(45)\end{array}$ & $\begin{array}{l}13 \% \\
(12)\end{array}$ & $\begin{array}{l}4 \% \\
(4)\end{array}$ & $\begin{array}{l}4 \% \\
(4)\end{array}$ & 2.0 & 2.0 & 91 \\
\hline $\begin{array}{c}\text { Created CDs } \\
\text { for } \\
\text { classroom } \\
\end{array}$ & $\begin{array}{l}27 \% \\
(24)\end{array}$ & $\begin{array}{l}44 \% \\
(40)\end{array}$ & $\begin{array}{l}18 \% \\
(16)\end{array}$ & $\begin{array}{l}8 \% \\
(7)\end{array}$ & $\begin{array}{l}3 \% \\
(3)\end{array}$ & 2.1 & 2.0 & 90 \\
\hline $\begin{array}{l}\text { Used ITunes } \\
\text { or other }\end{array}$ & $\begin{array}{l}52 \% \\
(48)\end{array}$ & $\begin{array}{l}26 \% \\
(24)\end{array}$ & $\begin{array}{l}11 \% \\
(10)\end{array}$ & $\begin{array}{l}7 \% \\
(6)\end{array}$ & $\begin{array}{l}4 \% \\
(4)\end{array}$ & 1.8 & 1.0 & 92 \\
\hline $\begin{array}{c}\text { Public } \\
\text { Domain } \\
\text { MIDI Files }\end{array}$ & $\begin{array}{l}61 \% \\
(56)\end{array}$ & $\begin{array}{l}27 \% \\
(25)\end{array}$ & $\begin{array}{l}5 \% \\
(5)\end{array}$ & $\begin{array}{l}4 \% \\
(4)\end{array}$ & $\begin{array}{l}2 \% \\
(2)\end{array}$ & 1.5 & 1.0 & 92 \\
\hline $\begin{array}{c}\text { Public } \\
\text { Domain } \\
\text { Audio Files }\end{array}$ & $\begin{array}{l}55 \% \\
(50)\end{array}$ & $\begin{array}{l}33 \% \\
(30)\end{array}$ & $\begin{array}{l}7 \% \\
(6)\end{array}$ & $\begin{array}{l}4 \% \\
(4)\end{array}$ & $\begin{array}{l}1 \% \\
(1)\end{array}$ & 1.6 & 1.0 & 91 \\
\hline $\begin{array}{l}\text { Used File } \\
\text { Sharing }\end{array}$ & $\begin{array}{l}63 \% \\
(57)\end{array}$ & $\begin{array}{l}25 \% \\
(23)\end{array}$ & $\begin{array}{l}5 \% \\
(5)\end{array}$ & $\begin{array}{l}5 \% \\
(5)\end{array}$ & $\begin{array}{l}1 \% \\
(1)\end{array}$ & 1.5 & 1.0 & 91 \\
\hline $\begin{array}{c}\text { Obtained } \\
\text { Audio from } \\
\text { Others }\end{array}$ & $\begin{array}{l}36 \% \\
(33)\end{array}$ & $\begin{array}{l}41 \% \\
(38)\end{array}$ & $\begin{array}{l}16 \% \\
(15)\end{array}$ & $\begin{array}{l}3 \% \\
(3)\end{array}$ & $\begin{array}{l}3 \% \\
(3)\end{array}$ & 1.9 & 2.0 & 92 \\
\hline
\end{tabular}


Digital audio software. The types and use of Digital Audio Software was studied to determine the frequency of use of the most common digital audio software available to music educators. While all data is indicated in Table 6, it is best analyzed for software usage by extracting responses that indicated any application in teaching, at any time. This information is illustrated in Figure 6, which shows the difference between answers of never used (5) and the sum of all other answers. The most prevalent software used is CD duplication software with a response of $60 \%$. This data, when compared to the number of teachers creating CDs for student or classroom use as illustrated in the previous Figure 3 and Table 5, is a likely and valid response. The second highest used software is notation software with a use rate of $54 \%$. Teachers reporting use of sample software (50\%) correlate with the notation software response as most notation software packages contain sampled sounds for audio playback. The responses for use of internal computer sounds similarly correspond to those using a computer in their music classroom. There is not frequent use of MIDI software, digital recording/editing software, MP3 software, or software instruments. 
Figure 6. Audio Software Use at Any Time

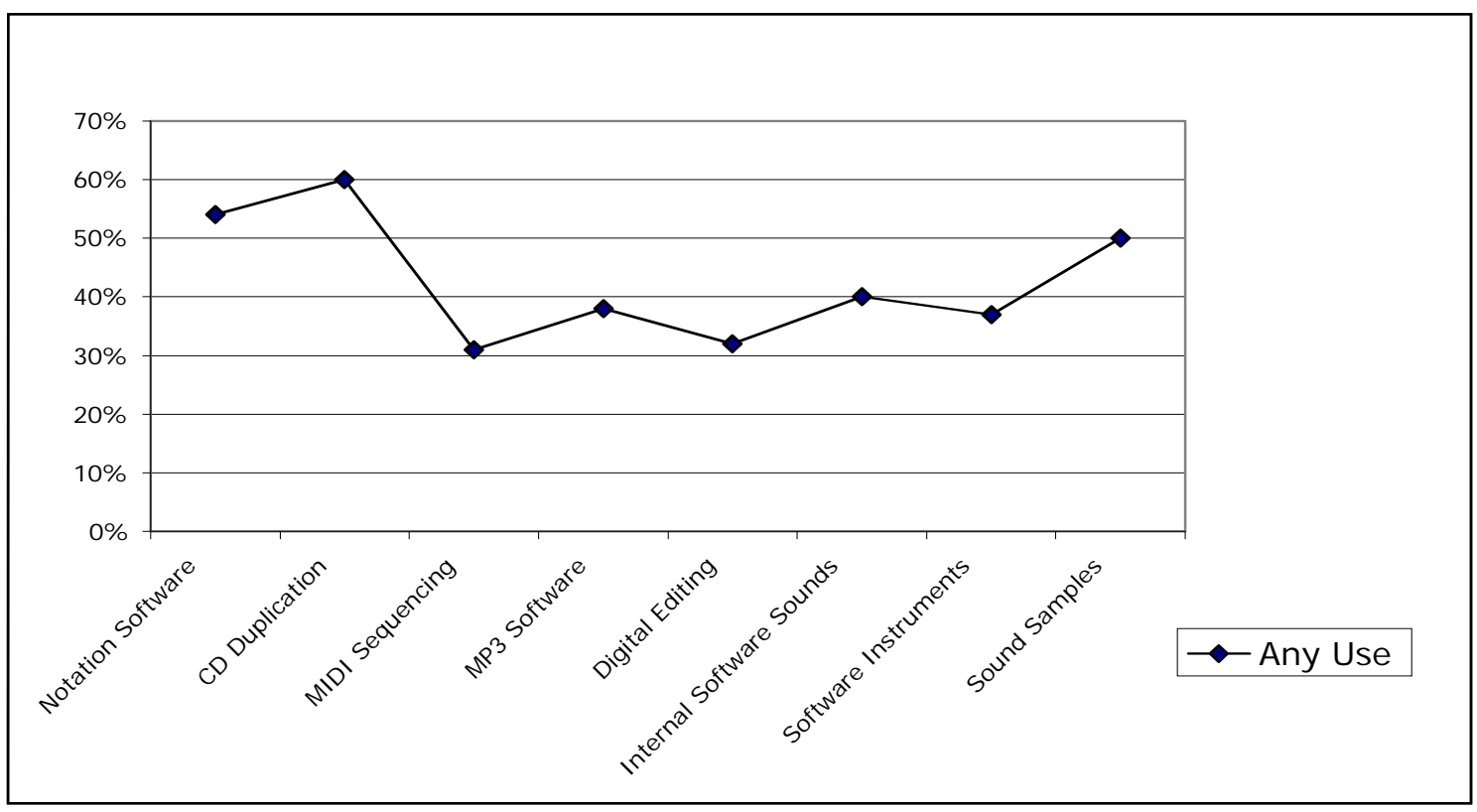

Further examination of the data, as illustrated in Table 6, shows that music teachers who use audio technology software weekly or greater use notation software and the aforementioned sound sample software most frequently Barely a quarter of respondents use CD duplication software within the same timeframe. Very few (12\%-15\%) use any MIDI sequencing or digital editing software. MP3 software was reported as $20 \%$ use, weekly or greater. This section of the survey also contained two questions regarding the most common computer operating systems. There is evidence that many music teachers may not be using a computer at all in their teaching. By examining the operating system answers, those using a computer, regardless of operating system, once a month or greater was $48 \%$ for Windows and $13 \%$ for Macintosh. The statistics indicate that nearly $45 \%$ of all respondents are not using or very rarely use a computer in their instruction. The mean of all answers was 1.9 
Table 6

Use of Digital Audio Technology Software $(N=93)$

\begin{tabular}{|c|c|c|c|c|c|c|c|c|}
\hline & 1 & 2 & 3 & 4 & 5 & $\mathrm{M}$ & Mdn & Responders \\
\hline $\begin{array}{l}\text { Notation } \\
\text { Software }\end{array}$ & $\begin{array}{c}46 \% \\
(43)\end{array}$ & $\begin{array}{l}24 \% \\
(22)\end{array}$ & $\begin{array}{l}10 \% \\
(9)\end{array}$ & $\begin{array}{l}12 \% \\
(11)\end{array}$ & $\begin{array}{l}9 \% \\
(8)\end{array}$ & 2.1 & 2.0 & 93 \\
\hline $\begin{array}{c}\text { CD } \\
\text { Duplication }\end{array}$ & $\begin{array}{l}40 \% \\
(37)\end{array}$ & $\begin{array}{l}36 \% \\
(33)\end{array}$ & $\begin{array}{l}12 \% \\
(11)\end{array}$ & $\begin{array}{c}10 \% \\
(9)\end{array}$ & $\begin{array}{l}2 \% \\
(2)\end{array}$ & 1.9 & 2.0 & 92 \\
\hline $\begin{array}{c}\text { MIDI } \\
\text { Sequencing }\end{array}$ & $\begin{array}{l}69 \% \\
(64)\end{array}$ & $\begin{array}{l}18 \% \\
(17)\end{array}$ & $\begin{array}{l}5 \% \\
(5)\end{array}$ & $\begin{array}{l}4 \% \\
(4)\end{array}$ & $\begin{array}{l}3 \% \\
(3)\end{array}$ & 1.5 & 1.0 & 93 \\
\hline MP3 & $\begin{array}{l}62 \% \\
(58)\end{array}$ & $\begin{array}{l}17 \% \\
(16)\end{array}$ & $\begin{array}{l}11 \% \\
(10)\end{array}$ & $\begin{array}{l}5 \% \\
(5)\end{array}$ & $\begin{array}{l}4 \% \\
(4)\end{array}$ & 1.7 & 1.0 & 93 \\
\hline $\begin{array}{c}\text { Digital } \\
\text { Recording/ } \\
\text { editing }\end{array}$ & $\begin{array}{l}68 \% \\
(63)\end{array}$ & $\begin{array}{l}17 \% \\
(16)\end{array}$ & $\begin{array}{l}12 \% \\
(11)\end{array}$ & $\begin{array}{l}2 \% \\
(2)\end{array}$ & $\begin{array}{l}1 \% \\
(1)\end{array}$ & 1.5 & 1.0 & 93 \\
\hline $\begin{array}{l}\text { Windows } \\
\text { OS }\end{array}$ & $\begin{array}{l}51 \% \\
(47)\end{array}$ & $\begin{array}{l}6 \% \\
(6)\end{array}$ & $\begin{array}{l}5 \% \\
(5)\end{array}$ & $\begin{array}{l}6 \% \\
(6)\end{array}$ & $\begin{array}{l}31 \% \\
(29)\end{array}$ & 2.6 & 1.0 & 93 \\
\hline Mac OS & $\begin{array}{l}87 \% \\
(77)\end{array}$ & $\begin{array}{l}1 \% \\
(1)\end{array}$ & $\begin{array}{l}1 \% \\
(1)\end{array}$ & $\begin{array}{l}1 \% \\
(1)\end{array}$ & $\begin{array}{c}10 \% \\
(9)\end{array}$ & 1.4 & 1.0 & 89 \\
\hline $\begin{array}{c}\text { Internal } \\
\text { Computer } \\
\text { Sounds } \\
\end{array}$ & $\begin{array}{c}60 \% \\
(56\end{array}$ & $\begin{array}{l}18 \% \\
(17)\end{array}$ & $\begin{array}{l}2 \% \\
(2)\end{array}$ & $\begin{array}{l}12 \% \\
(11)\end{array}$ & $\begin{array}{l}8 \% \\
(7)\end{array}$ & 1.8 & 1.0 & 93 \\
\hline $\begin{array}{c}\text { Software } \\
\text { Instruments }\end{array}$ & $\begin{array}{l}63 \% \\
(58)\end{array}$ & $\begin{array}{l}20 \% \\
(18)\end{array}$ & $\begin{array}{l}8 \% \\
(7)\end{array}$ & $\begin{array}{l}2 \% \\
(2)\end{array}$ & $\begin{array}{l}8 \% \\
(7)\end{array}$ & 1.7 & 1.0 & 92 \\
\hline Samples & $\begin{array}{l}50 \% \\
(46)\end{array}$ & $\begin{array}{l}25 \% \\
(23)\end{array}$ & $\begin{array}{l}12 \% \\
(11)\end{array}$ & $\begin{array}{l}5 \% \\
(5)\end{array}$ & $\begin{array}{l}8 \% \\
(7)\end{array}$ & 1.9 & 1.5 & 92 \\
\hline
\end{tabular}

Research Question 3: What skills have WV Public School Music teachers acquired to utilize digital audio technologies for access, manipulation, dissemination, and use in teaching music education? 
In this section of the survey, music educators were asked to rate their current abilities with digital audio technologies to determine the extent of skill, confidence, and self-perception of knowledge. This data helped to answer RQ 3. Interview and observation data used to answer RQ3 are reported later in this chapter. For the survey, a Likert scale that measures the extent to which respondents agreed or disagreed with the questions was utilized. The scale was 1 to 5 with the answer criteria being 1 = never tried, 2 = beginner, 3 = intermediate, and $4=$ advanced.

Digital audio technology skills. As indicated in Table 7, music teachers feel strongest in their abilities in using audio CDs and manipulating or creating CDs from other CDs or other audio sources. Seventy five percent believed that they had intermediate or advance skills in using CD-ROMs in the classroom. The next order of advanced expertise was in the area of skills in downloading written music or digital audio files. Thirty-three percent of music teachers believe they have advanced skills in this area. An average of 25\% of individuals reported advance skill in downloading audio material from file sharing sites, the public domain, or from a commercial audio file site. Twenty-seven percent and 28\% reported advanced skills in the use of both MIDI and MP3 files respectively. Similarly, 30\% and 29\% reported never trying these applications. Significant reports in the 40 percent range of having never tried certain technologies exist in the areas of MIDI file creation, audio file editing, and downloading files from a file sharing site or the public domain. More than half of the music teachers have never tried subscribing to a podcast, using Internet radio in the classroom, or recording Internet streaming of audio material. The greatest percentages of music teachers responding have never tried using a DAT recorder (73\%). The mean of all answers was 2.3. 
Table 7

Self Rating of Current Abilities with Digital Audio Technologies ( $\mathrm{N}=92)$

\begin{tabular}{|c|c|c|c|c|c|c|c|}
\hline & 1 & 2 & 3 & 4 & $\mathrm{M}$ & Mdn & Responders \\
\hline $\begin{array}{l}\text { Use Audio CDs } \\
\text { in the classroom }\end{array}$ & $\begin{array}{l}2 \% \\
(2)\end{array}$ & $\begin{array}{l}0 \% \\
(0)\end{array}$ & $\begin{array}{l}13 \% \\
(12)\end{array}$ & $\begin{array}{l}85 \% \\
(78)\end{array}$ & 3.8 & 4.0 & 92 \\
\hline $\begin{array}{l}\text { Use CD-ROMs } \\
\text { in the classroom }\end{array}$ & $\begin{array}{l}12 \% \\
(11)\end{array}$ & $\begin{array}{l}13 \% \\
(12)\end{array}$ & $\begin{array}{l}30 \% \\
(27)\end{array}$ & $\begin{array}{l}45 \% \\
(41)\end{array}$ & 3.0 & 3.0 & 91 \\
\hline $\begin{array}{l}\text { Create my own } \\
\text { CDs from other } \\
\text { CDs }\end{array}$ & $\begin{array}{l}9 \% \\
(8)\end{array}$ & $\begin{array}{l}14 \% \\
(13)\end{array}$ & $\begin{array}{l}24 \% \\
(22)\end{array}$ & $\begin{array}{l}52 \% \\
(47)\end{array}$ & 3.2 & 4.0 & 90 \\
\hline $\begin{array}{l}\text { Create CDs from } \\
\text { other audio } \\
\text { sources }\end{array}$ & $\begin{array}{l}14 \% \\
(13)\end{array}$ & $\begin{array}{l}21 \% \\
(19)\end{array}$ & $\begin{array}{l}24 \% \\
(22)\end{array}$ & $\begin{array}{l}41 \% \\
(38)\end{array}$ & 2.9 & 3.0 & 92 \\
\hline Used MP3 files & $\begin{array}{l}29 \% \\
(27)\end{array}$ & $\begin{array}{l}22 \% \\
(20)\end{array}$ & $\begin{array}{l}21 \% \\
(19)\end{array}$ & $\begin{array}{l}28 \% \\
(26)\end{array}$ & 2.5 & 2.0 & 92 \\
\hline Used Midi file & $\begin{array}{l}30 \% \\
(28)\end{array}$ & $\begin{array}{l}23 \% \\
(21)\end{array}$ & $\begin{array}{l}20 \% \\
(18)\end{array}$ & $\begin{array}{l}27 \% \\
(25)\end{array}$ & 2.4 & 2.0 & 92 \\
\hline $\begin{array}{l}\text { Create a MIDI } \\
\text { file }\end{array}$ & $\begin{array}{l}45 \% \\
(41)\end{array}$ & $\begin{array}{l}22 \% \\
(20)\end{array}$ & $\begin{array}{l}16 \% \\
(15\end{array}$ & $\begin{array}{c}17 \% \\
(16\end{array}$ & 2.1 & 2.0 & 92 \\
\hline $\begin{array}{l}\text { Edit an audio } \\
\text { file }\end{array}$ & $\begin{array}{l}40 \% \\
(36)\end{array}$ & $\begin{array}{l}26 \% \\
(23)\end{array}$ & $\begin{array}{l}17 \% \\
(15)\end{array}$ & $\begin{array}{l}17 \% \\
(15)\end{array}$ & 2.1 & 2.0 & 89 \\
\hline $\begin{array}{l}\text { Download a } \\
\text { piece of written } \\
\text { music (PDF or } \\
\text { other format) }\end{array}$ & $\begin{array}{l}27 \% \\
(25)\end{array}$ & $\begin{array}{l}20 \% \\
(18)\end{array}$ & $\begin{array}{l}21 \% \\
(19)\end{array}$ & $\begin{array}{l}33 \% \\
(30)\end{array}$ & 2.6 & 3.0 & 92 \\
\hline $\begin{array}{l}\text { Download a } \\
\text { midi file }\end{array}$ & $\begin{array}{l}29 \% \\
(26)\end{array}$ & $\begin{array}{l}22 \% \\
(20)\end{array}$ & $\begin{array}{l}16 \% \\
(14)\end{array}$ & $\begin{array}{l}33 \% \\
(30)\end{array}$ & 2.5 & 2.0 & 90 \\
\hline $\begin{array}{l}\text { Use the Internet } \\
\text { to disseminate } \\
\text { audio }\end{array}$ & $\begin{array}{l}37 \% \\
(34)\end{array}$ & $\begin{array}{c}23 \% \\
(21\end{array}$ & $\begin{array}{c}22 \% \\
(20\end{array}$ & $\begin{array}{l}18 \% \\
(16)\end{array}$ & 2.2 & 2.0 & 91 \\
\hline
\end{tabular}

(table continues) 
Self Rating of Current Abilities with Digital Audio Technologies (N=92) (Continued)

\begin{tabular}{|c|c|c|c|c|c|c|c|}
\hline & 1 & 2 & 3 & 4 & $\mathrm{M}$ & Mdn & Responders \\
\hline $\begin{array}{l}\text { Use a web page } \\
\text { to disseminate } \\
\text { audio } \\
\text { information }\end{array}$ & $\begin{array}{l}41 \% \\
(37)\end{array}$ & $\begin{array}{l}22 \% \\
(20\end{array}$ & $\begin{array}{l}22 \% \\
(20)\end{array}$ & $\begin{array}{l}15 \% \\
(14)\end{array}$ & 2.1 & 2.0 & 91 \\
\hline $\begin{array}{l}\text { Use digital audio } \\
\text { hardware }\end{array}$ & $\begin{array}{l}38 \% \\
(35)\end{array}$ & $\begin{array}{l}27 \% \\
(25)\end{array}$ & $\begin{array}{l}19 \% \\
(17)\end{array}$ & $\begin{array}{l}15 \% \\
(14)\end{array}$ & 2.1 & 2.0 & 91 \\
\hline $\begin{array}{l}\text { Use digital audio } \\
\text { software }\end{array}$ & $\begin{array}{l}39 \% \\
(36)\end{array}$ & $\begin{array}{l}27 \% \\
(25)\end{array}$ & $\begin{array}{l}18 \% \\
(17)\end{array}$ & $\begin{array}{l}15 \% \\
(14)\end{array}$ & 2.1 & 2.0 & 92 \\
\hline $\begin{array}{l}\text { Use an I-pod or } \\
\text { Podcast }\end{array}$ & $\begin{array}{l}35 \% \\
(32)\end{array}$ & $\begin{array}{l}18 \% \\
(17)\end{array}$ & $\begin{array}{l}18 \% \\
(17)\end{array}$ & $\begin{array}{l}28 \% \\
(26)\end{array}$ & 2.4 & 2.0 & 92 \\
\hline $\begin{array}{l}\text { Subscribe to a } \\
\text { Podcast }\end{array}$ & $\begin{array}{l}60 \% \\
(55)\end{array}$ & $\begin{array}{l}13 \% \\
(12)\end{array}$ & $\begin{array}{l}12 \% \\
(11)\end{array}$ & $\begin{array}{l}14 \% \\
(13)\end{array}$ & 1.8 & 1.0 & 91 \\
\hline $\begin{array}{l}\text { Purchase music } \\
\text { from a } \\
\text { commercial } \\
\text { download site }\end{array}$ & $\begin{array}{l}38 \% \\
(35)\end{array}$ & $\begin{array}{l}13 \% \\
(12)\end{array}$ & $\begin{array}{l}23 \% \\
(21)\end{array}$ & $\begin{array}{l}26 \% \\
(24)\end{array}$ & 2.4 & 2.0 & 92 \\
\hline $\begin{array}{l}\text { Download music } \\
\text { from a file } \\
\text { sharing site } \\
\end{array}$ & $\begin{array}{l}41 \% \\
(37)\end{array}$ & $\begin{array}{l}26 \% \\
(24)\end{array}$ & $\begin{array}{l}8 \% \\
(7)\end{array}$ & $\begin{array}{l}25 \% \\
(23)\end{array}$ & 2.2 & 2.0 & 91 \\
\hline $\begin{array}{l}\text { Download music } \\
\text { files in the } \\
\text { public domain }\end{array}$ & $\begin{array}{l}43 \% \\
(40)\end{array}$ & $\begin{array}{l}20 \% \\
(18)\end{array}$ & $\begin{array}{l}14 \% \\
(13)\end{array}$ & $\begin{array}{l}23 \% \\
(21)\end{array}$ & 2.2 & 2.0 & 92 \\
\hline $\begin{array}{l}\text { Use Internet } \\
\text { radio in the } \\
\text { classroom } \\
\text { Use a DAT }\end{array}$ & $\begin{array}{l}65 \% \\
(60)\end{array}$ & $\begin{array}{l}12 \% \\
(11)\end{array}$ & $\begin{array}{l}12 \% \\
(11)\end{array}$ & $\begin{array}{l}11 \% \\
(10)\end{array}$ & 1.7 & 1.0 & 92 \\
\hline $\begin{array}{l}\text { Use a DAT } \\
\text { recorder }\end{array}$ & $\begin{array}{l}73 \% \\
(67)\end{array}$ & $\begin{array}{l}16 \% \\
(15)\end{array}$ & $\begin{array}{l}7 \% \\
(6)\end{array}$ & $\begin{array}{l}4 \% \\
(4)\end{array}$ & 1.4 & 1.0 & 92 \\
\hline $\begin{array}{l}\text { Record Internet } \\
\text { radio or music } \\
\text { streaming }\end{array}$ & $\begin{array}{l}62 \% \\
(57)\end{array}$ & $\begin{array}{l}16 \% \\
(15)\end{array}$ & $\begin{array}{l}14 \% \\
(13)\end{array}$ & $\begin{array}{l}8 \% \\
(7)\end{array}$ & 1.7 & 1.0 & 92 \\
\hline
\end{tabular}


When examining those who have never tried or rate themselves as a beginner, areas which might require further education and training to benefit the music educator can be found. Figure 7 illustrates respondents who answered having never tried or being a beginner in their abilities with digital audio technologies. The hierarchy of this data finds digital audio tape techniques, Internet radio, podcasting, and creation of MIDI or audio files as the areas of least activity or skill.

Figure 7. Teachers who have never tried or rated their skills as beginner, in using digital audio technologies.

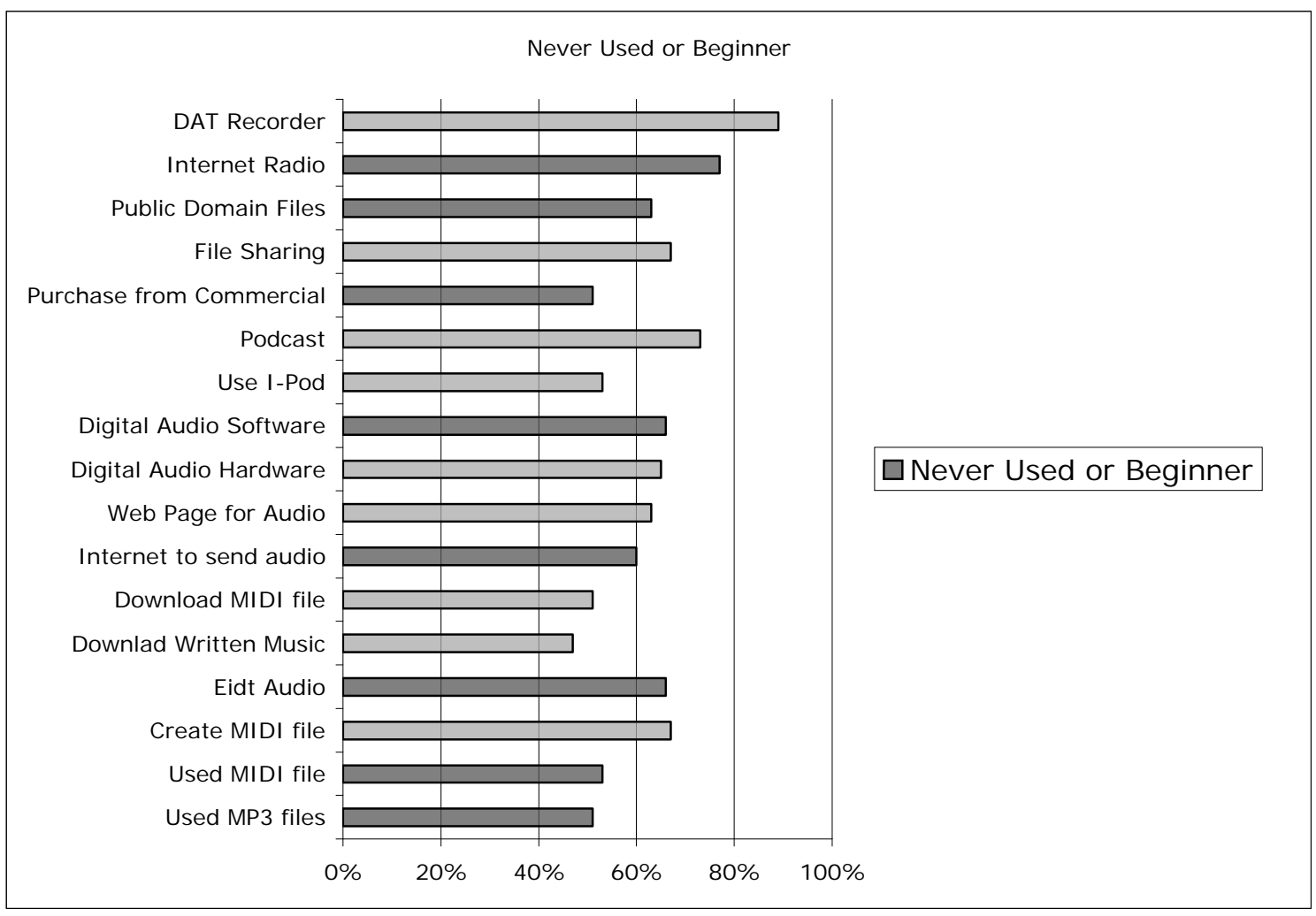

Teaching decisions. Educational and teaching decisions were studied to determine what preparation or instruction music teachers experienced towards the use of digital audio technologies, why they used these technologies, whether they could plan for the technology's integration into their instruction, and if they had the knowledge and skill to create lessons and 
teaching objects which utilized digital audio materials. This data was used to answer RQ3 and RQ4. A Likert scale that measures the extent to which respondents agreed or disagreed with the questions was used. The scale was 1 to 5 with the answer criteria being $1=$ Strongly Disagree, 2 = Disagree, 3 = Neutral, $4=$ Agree, and 5 = Strongly Agree .

As indicated in Table 8, nearly 50\% of the teachers reported receiving instruction from their students. To a lesser extent, knowledge gained in the use of digital audio technologies was obtained in summer workshops and self-instruction via the Internet. Sixty-five percent strongly disagreed to the questions of having received training in their undergraduate study or from inservice workshops. Similarly, instruction by peers showed a response of $40 \%$ strongly disagreeing and 20\% disagreeing.

Data collected regarding the reasons for use of digital audio technologies in teaching produced the most significant number of responses in the neutral category. With the exception of using audio technology to meet Content Specific Objectives for technology use by students, the range of means reported was 2.8 to 3.0 . While $12 \%$ to $14 \%$ strongly agreed to all reasons for use. If the response of Agree and Strongly Agree are summed, the interval data shows that the primary reason for using digital audio technology is to meet Content Standard Objectives for music knowledge by students. $46 \%$ of the teachers responded positively. Using the same analysis, $43 \%$ cited ease of distribution for a reason of use.

Survey items, which addressed designing lessons and planning strategies that include digital audio technologies, were similarly examined using interval data obtained by the sums of Strongly Agree and Agree and compared to the sums of Strongly Disagree and Disagree. A majority of teachers (48\%) reported positively in regards to their ability to operate and apply hardware to support learning as to those who responded negatively (36\%). The ability to create 
materials which enhanced teaching strategies yielded similar results with $45 \%$ in agreement and 38\% in disagreement. Negative relationships were observed in the areas of designing lessons and planning strategies that enhanced student learning. Forty-one percent and $46 \%$ were in disagreement respectively. Balanced perspectives of agreement and disagreement are shown in the categories of creating materials which enhanced learning and use to support student centered activities. Music teachers believe they have a familiarity with copyright and digital audio examples with the strongest levels of agreement (61\%) being reported. The mean of all answers was 2.7.

Table 8

Responses Regarding Education and Teaching Decisions $(\mathrm{N}=89)$

\begin{tabular}{|c|c|c|c|c|c|c|c|c|}
\hline & 1 & 2 & 3 & 4 & 5 & $\mathrm{M}$ & Mdn & Responders \\
\hline $\begin{array}{l}\text { Under- } \\
\text { graduate } \\
\text { study }\end{array}$ & $\begin{array}{l}65 \% \\
(58)\end{array}$ & $\begin{array}{c}11 \% \\
(10\end{array}$ & $\begin{array}{l}7 \% \\
(6)\end{array}$ & $\begin{array}{l}12 \% \\
(11)\end{array}$ & $\begin{array}{l}4 \% \\
(4)\end{array}$ & 1.8 & 1.0 & 89 \\
\hline $\begin{array}{l}\text { In-Service } \\
\text { workshops }\end{array}$ & $\begin{array}{l}65 \% \\
(55)\end{array}$ & $\begin{array}{l}8 \% \\
(7)\end{array}$ & $\begin{array}{l}17 \% \\
(14)\end{array}$ & $\begin{array}{l}6 \% \\
(5)\end{array}$ & $\begin{array}{l}4 \% \\
(3)\end{array}$ & 1.7 & 1.0 & 84 \\
\hline $\begin{array}{l}\text { Summer } \\
\text { workshops }\end{array}$ & $\begin{array}{l}33 \% \\
(29)\end{array}$ & $\begin{array}{c}16 \% \\
(14\end{array}$ & $\begin{array}{l}9 \% \\
(8)\end{array}$ & $\begin{array}{l}33 \% \\
(29)\end{array}$ & $\begin{array}{c}10 \% \\
(9)\end{array}$ & 2.7 & 3.0 & 89 \\
\hline From peers & $\begin{array}{l}40 \% \\
(35)\end{array}$ & $\begin{array}{l}20 \% \\
(18)\end{array}$ & $\begin{array}{l}8 \% \\
(7)\end{array}$ & $\begin{array}{l}23 \% \\
(20)\end{array}$ & $\begin{array}{l}9 \% \\
(8)\end{array}$ & 2.4 & 2.0 & 88 \\
\hline $\begin{array}{l}\text { From } \\
\text { students }\end{array}$ & $\begin{array}{l}26 \% \\
(23)\end{array}$ & $\begin{array}{l}16 \% \\
(14)\end{array}$ & $\begin{array}{l}8 \% \\
(7)\end{array}$ & $\begin{array}{l}40 \% \\
(35)\end{array}$ & $\begin{array}{l}9 \% \\
(8)\end{array}$ & 2.9 & 3.0 & 87 \\
\hline $\begin{array}{l}\text { From } \\
\text { Internet }\end{array}$ & $\begin{array}{l}31 \% \\
(26)\end{array}$ & $\begin{array}{l}20 \% \\
(17)\end{array}$ & $\begin{array}{l}12 \% \\
(10)\end{array}$ & $\begin{array}{l}32 \% \\
(27)\end{array}$ & $\begin{array}{l}6 \% \\
(5)\end{array}$ & 2.6 & 2.0 & 85 \\
\hline
\end{tabular}

Responses Regarding Education and Teaching Decisions ( $\mathrm{N}=89)$ (Continued)

(table continues)

$\begin{array}{llllllll}1 & 2 & 3 & 4 & 5 & M & \text { Mdn } & \text { Responders }\end{array}$




\begin{tabular}{|c|c|c|c|c|c|c|c|c|}
\hline $\begin{array}{l}\text { Use to meet } \\
\text { CSOs for } \\
\text { use by } \\
\text { students }\end{array}$ & $\begin{array}{l}39 \% \\
(34)\end{array}$ & $\begin{array}{l}16 \% \\
(14)\end{array}$ & $\begin{array}{l}14 \% \\
(12)\end{array}$ & $\begin{array}{l}24 \% \\
(21)\end{array}$ & $\begin{array}{l}7 \% \\
(6)\end{array}$ & 2.4 & 2.0 & 87 \\
\hline $\begin{array}{l}\text { Use to meet } \\
\text { CSOs for } \\
\text { music } \\
\text { knowledge } \\
\text { by students }\end{array}$ & $\begin{array}{l}21 \% \\
(18)\end{array}$ & $\begin{array}{l}14 \% \\
(12)\end{array}$ & $\begin{array}{l}20 \% \\
(17)\end{array}$ & $\begin{array}{l}32 \% \\
(28)\end{array}$ & $\begin{array}{l}14 \% \\
(12)\end{array}$ & 3.0 & 3.0 & 87 \\
\hline $\begin{array}{l}\text { Use because } \\
\text { of ease of } \\
\text { distribution }\end{array}$ & $\begin{array}{l}20 \% \\
(17)\end{array}$ & $\begin{array}{l}11 \% \\
(10)\end{array}$ & $\begin{array}{l}26 \% \\
(23)\end{array}$ & $\begin{array}{l}29 \% \\
(25)\end{array}$ & $\begin{array}{l}14 \% \\
(12)\end{array}$ & 3.0 & 3.0 & 87 \\
\hline $\begin{array}{l}\text { Use because } \\
\text { of } \\
\text { accessibility }\end{array}$ & $\begin{array}{l}24 \% \\
(20)\end{array}$ & $\begin{array}{l}12 \% \\
(10)\end{array}$ & $\begin{array}{l}31 \% \\
(26)\end{array}$ & $\begin{array}{c}20 \% \\
(17)\end{array}$ & $\begin{array}{l}14 \% \\
(12)\end{array}$ & 2.9 & 3.0 & 85 \\
\hline $\begin{array}{l}\text { Use because } \\
\text { of ease of } \\
\text { editing }\end{array}$ & $\begin{array}{l}25 \% \\
(21)\end{array}$ & $\begin{array}{l}16 \% \\
(14)\end{array}$ & $\begin{array}{l}25 \% \\
(21)\end{array}$ & $\begin{array}{c}22 \% \\
(19)\end{array}$ & $\begin{array}{l}12 \% \\
(10)\end{array}$ & 2.8 & 3.0 & 85 \\
\hline $\begin{array}{l}\text { Designed } \\
\text { lessons that } \\
\text { utilize }\end{array}$ & $\begin{array}{l}26 \% \\
(22)\end{array}$ & $\begin{array}{l}15 \% \\
(13)\end{array}$ & $\begin{array}{l}26 \% \\
(22)\end{array}$ & $\begin{array}{l}19 \% \\
(16)\end{array}$ & $\begin{array}{l}13 \% \\
(11)\end{array}$ & 2.8 & 3.0 & 84 \\
\hline $\begin{array}{l}\text { Planned } \\
\text { strategies } \\
\text { that enhance } \\
\text { student } \\
\text { learning }\end{array}$ & $\begin{array}{l}32 \% \\
(27)\end{array}$ & $\begin{array}{l}14 \% \\
(12)\end{array}$ & $\begin{array}{l}13 \% \\
(11)\end{array}$ & $\begin{array}{l}27 \% \\
(23)\end{array}$ & $\begin{array}{l}14 \% \\
(12)\end{array}$ & 2.8 & 3.0 & 85 \\
\hline $\begin{array}{l}\text { Create } \\
\text { materials } \\
\text { that enhance } \\
\text { learning }\end{array}$ & $\begin{array}{l}23 \% \\
(20)\end{array}$ & $\begin{array}{l}15 \% \\
(13)\end{array}$ & $\begin{array}{l}21 \% \\
(18)\end{array}$ & $\begin{array}{l}24 \% \\
(21)\end{array}$ & $\begin{array}{l}16 \% \\
(14)\end{array}$ & 3.0 & 3.0 & 86 \\
\hline $\begin{array}{l}\text { Can create } \\
\text { materials } \\
\text { that enhance } \\
\text { teaching } \\
\text { strategies } \\
\end{array}$ & $\begin{array}{l}23 \% \\
(20)\end{array}$ & $\begin{array}{l}15 \% \\
(13)\end{array}$ & $\begin{array}{l}16 \% \\
(14)\end{array}$ & $\begin{array}{l}30 \% \\
(26)\end{array}$ & $\begin{array}{l}15 \% \\
(13)\end{array}$ & 3.0 & 3.0 & 86 \\
\hline
\end{tabular}


Responses Regarding Education and Teaching Decisions ( $N=89)$ (Continued)

\begin{tabular}{|c|c|c|c|c|c|c|c|c|}
\hline & 1 & 2 & 3 & 4 & 5 & M & Mdn & Responders \\
\hline $\begin{array}{l}\text { Use to } \\
\text { support } \\
\text { student } \\
\text { centered } \\
\text { activities }\end{array}$ & $\begin{array}{l}30 \% \\
(25)\end{array}$ & $\begin{array}{l}12 \% \\
(10)\end{array}$ & $\begin{array}{l}17 \% \\
(14)\end{array}$ & $\begin{array}{l}26 \% \\
(22)\end{array}$ & $\begin{array}{l}15 \% \\
\text { (13) }\end{array}$ & 2.9 & 3.0 & 84 \\
\hline $\begin{array}{l}\text { Can operate } \\
\text { and apply } \\
\text { hardware to } \\
\text { support } \\
\text { learning }\end{array}$ & $\begin{array}{l}20 \% \\
(17)\end{array}$ & $\begin{array}{l}16 \% \\
(14)\end{array}$ & $\begin{array}{l}15 \% \\
(13)\end{array}$ & $\begin{array}{l}34 \% \\
\text { (29) }\end{array}$ & $\begin{array}{l}14 \% \\
(12)\end{array}$ & 3.1 & 3.0 & 85 \\
\hline $\begin{array}{l}\text { Familiarity } \\
\text { with } \\
\text { copyright } \\
\text { for digital } \\
\text { audio } \\
\text { examples }\end{array}$ & $\begin{array}{c}11 \% \\
(9)\end{array}$ & $\begin{array}{c}11 \% \\
(9)\end{array}$ & $\begin{array}{l}18 \% \\
(15)\end{array}$ & $\begin{array}{l}35 \% \\
(30)\end{array}$ & $\begin{array}{l}26 \% \\
(22)\end{array}$ & 3.6 & 4.0 & 85 \\
\hline
\end{tabular}

Interviews

Upon completion of the self-reporting survey deadline, 24 participants were carefully selected based on the criterion sampling strategy. Participants were selected using the following criteria in order of importance:

- Willingness to be interviewed and potential for observation of lessons

- Aggregate score of skills summary (Survey Question 13) [24]

- Grade and Area of Instruction (Survey Questions 1 and 2)

- RESA served

Personal interviews were conducted at the time and location chosen by the identified participants. Six interviews were conducted by phone. The interviews were recorded for later transcription and coding. All participants agreed to be taped. Before the interview began they were reminded, that their participation was voluntary, they were being recorded, and their 
identity would remain anonymous. During the interview, the researcher took notes and observed sample uses of digital audio technologies when demonstrated by the participant. See Appendix B for the interview protocol and questions. Table 9 represents the demographic information of all individuals being interviewed, their area of instruction, and their years of music teaching experience. Twenty-four active music educators were interviewed. These interviews were used to answer RQ3, RQ4, and RQ5.

Table 9

Demographics of Interview Participants, Areas(s) of Instruction, and Years Experience

\begin{tabular}{|c|c|c|c|c|c|c|c|c|}
\hline Participant & Elementary & Middle/JR. High & High School & $\mathrm{G}$ & $\mathrm{I}$ & $\mathrm{C}$ & $\mathrm{S}$ & Years \\
\hline 1 & $\mathrm{X}$ & & & $\mathrm{X}$ & & & & 6 \\
\hline 2 & $X$ & $X$ & & & & & $X$ & 3 \\
\hline 3 & & & $\mathrm{X}$ & & $X$ & & & 20 \\
\hline 4 & & $\mathrm{X}$ & & $\mathrm{X}$ & & $\mathrm{X}$ & & 22 \\
\hline 5 & $\mathrm{X}$ & & & $\mathrm{X}$ & & & & 10 \\
\hline 6 & & & $\mathrm{X}$ & & $X$ & & & 10 \\
\hline 7 & & $X$ & & $\mathrm{X}$ & & $\mathrm{X}$ & & 12 \\
\hline 8 & $\mathrm{X}$ & & & $\mathrm{X}$ & & & & 15 \\
\hline 9 & & $\mathrm{X}$ & & $\mathrm{X}$ & $X$ & & & 10 \\
\hline 10 & $\mathrm{X}$ & & & $\mathrm{X}$ & & & & 14 \\
\hline 11 & & & $\mathrm{X}$ & & & & $\mathrm{X}$ & 12 \\
\hline 12 & & & $X$ & & $\mathrm{X}$ & & & 9 \\
\hline 13 & & & $\mathrm{X}$ & & & $\mathrm{X}$ & & 7 \\
\hline 14 & & $\mathrm{X}$ & & $\mathrm{X}$ & $\mathrm{X}$ & $\mathrm{X}$ & & 10 \\
\hline 15 & $\mathrm{X}$ & & & $\mathrm{X}$ & & & & 34 \\
\hline 16 & & $\mathrm{X}$ & & $\mathrm{X}$ & $\mathrm{X}$ & & & 16 \\
\hline 17 & & & $\mathrm{X}$ & & & $\mathrm{X}$ & & 3 \\
\hline 18 & & $X$ & & & & $\mathrm{X}$ & & 8 \\
\hline 19 & $\mathrm{X}$ & & & & & & & 15 \\
\hline 20 & $X$ & $\mathrm{X}$ & & & $\mathrm{X}$ & & & 16 \\
\hline 21 & & $X$ & $X$ & & $X$ & $X$ & & 10 \\
\hline 22 & & & $X$ & $\mathrm{X}$ & & $X$ & & 21 \\
\hline 23 & & & $X$ & & & & & 12 \\
\hline 24 & $\mathrm{X}$ & & & $\mathrm{X}$ & & $\mathrm{X}$ & & 8 \\
\hline
\end{tabular}


Research Question 3: What skills have WV Public School Music teachers acquired to utilize digital audio technologies for access, manipulation, dissemination, and use in teaching music education?

To assist in answering how teachers have obtained skills using music technologies (RQ3), interview questions one to three were used (Appendix B). A conceptual framework, which used the four guiding areas of comfort level in learning, contribution to use, barriers to use, and skill acquisition, allowed the highlighting of repeated key words and phrases. Like phrases were clustered which produced obvious emergent themes and significant answers. Unique phrases and themes, representative of a minority of responses were ranked by frequency and included as part of the analysis to answer the RQ.

Comfort level. Only one interview produced commentary which reflected a negative attitude towards having a desire to learn digital audio technologies. This commentary appeared to be based in frustration towards the acquisition of sufficient enough skills to use the technology. A Middle School teacher of 16 years responded:

I simply do not have the time to learn what I need to and then do what I want to do. I can see where there might be benefits but I just cannot find the small steps it would take to lead me to larger steps. So, basically, I do not try.

A significant majority simply responded with an affirmative when asked if they were comfortable learning new audio technologies. Follow up prompting produced a primary reason for having desires to learn from half of the respondents. Regardless of discipline or level of teaching, all comments could be paraphrased by the answers of an experienced elementary teacher.

I seek to learn because I do not want to be left behind. Our kids and our classrooms are 
changing faster than ever before. I especially do not want to not be able to relate to the

kids. I mean, I needed to use what they are using. Being left behind scares me.

Younger teachers felt that they had a longer learning curve for implementation. It was not the technology that curbed their desire, it was how it fit into the curriculum they were still adjusting to. Teachers with three and six years respectively, felt their age made it "comfortable” to learn any technology. While all voiced favorable desires, it was encapsulated by a veteran middle school teacher of 16 years, who said that "The wide range of creative opportunities continually contributes to my desire to learn and to use the technology.”

Contributions to use. While teachers were quick to point out barriers towards their use of digital audio technologies, several provided examples of things which contributed to their use and engagement in teaching with the technology. Key phrases included alternative funding sources, the availability of web materials, and the adoption of a new curriculum series which contained significant new materials on CD and CDROM.

Summarizing alternate financing, a HS choral teacher of seven years remarked:

Thank God for my parent organization. They have picked up the financial slack and provided what the county cannot. Without them I wouldn't have any advanced stuff like presentation equipment with decent audio.

A significant keyword emerged within this portion of the interviews. This was a strong usage of the term interactivity. Respondents felt that there is a significant amount of audio materials available, via the web, to engage their students. This alone, was a majority of cited reasons for using digital audio technologies when available. The perception was that engagement with the World Wide Web was a very valid music education experience. A senior high teacher commented: 
I love the availability of interactive web sites with enriched audio. I have really started to use them in many of my lessons. I use these sites in my classroom presentations and plan to try and use them in our computer lab.

Elementary and Middle School teacher’s interviews provided one central theme. This was their new involvement with materials from the newly adopted curriculum and included I-Pods and sound docks. Only two music teachers at this grade level made no mention of the new series. One elementary teacher was very enthusiastic commenting that "the new series is an asset. It makes me want to dig deeper into the materials they have provided including the audio and video clips as well as the animated listening maps on CD-ROM.”

Several also pointed out that the audio quality of the new material was far superior to previously provided audio. They, and the students, loved the new sound. Through out the interviews, music teachers continually referenced their students and students helping them learn. It became evident that regardless of desires, impediments, and skill level, paramount to the purpose of using audio technologies was the successful involvement of the learner. This was illustrated quite succinctly by a middle school teacher:

After 17 years of teaching I am seeing that students truly want the sensory input and immediate response provided by many audio technologies. I believe that they are cognitively better and the kids are better reached and served therefore I seek to implement these technologies.

A minority of answers cited some specific hardware provided by their school in the area of interactive presentation boards (Smart-Boards). Those music teachers were quick to point out that although such an apparatus was not a digital audio device, it certainly served as a catalyst for their engagement of audio sites on the web as well as a fresh way to present traditional music 
materials which, in their opinion, kept the students attention. Several remarked that it was now easier to teach music notation (High School) than ever before.

Barriers. When interviewed as to what barriers have confined an individual teachers use of digital audio technology, three primary recurring themes emerged. Four additional barriers had multiple references within the stratus of grade level taught. These themes and applicable grade level are shown in Figure 8, which is preceded by the following synopsis.

All interviews contained references towards the need for more funding as part of their answer. While most respondents simply stated that funding for equipment was the greatest barrier, many offered more specific examples of what these funding activities would encompass. Items included were specific equipment purchases, namely computers, audio equipment, speakers, and software. There was a clear consensus that financial support or lack thereof was an impediment in using digital audio technologies. A very pragmatic answer was gleaned from a teacher with 34 years experience. She said that "Certainly money is a factor especially in the smaller schools. Why put resources just into music when the general classrooms need it?”

Secondary to these comments was considerable mention of out-of-date equipment by teachers of all ages. A middle school band director commented that "Even on school computers this is a problem For example, we have notation software but the school computers do not have enough RAM to run it.”

The third most recurring theme was one of lack of training. While a significant majority reported that their skills were obtained by trial and error, many commented on the lack of training provided either in county sponsored workshops, in-services, or at state conventions. This was noted by a greater number of elementary and middle school teachers. Quality of provided training was also of concern, as one teacher commented that "I attend all trainings but 
many are heavy handed and have questionable application (elementary).”

Middle and high school music teachers also had a high frequency of response, which addressed both their students' lack of home technology due to socioeconomic reasons and available bandwidth. Middle school teachers, and one high school teacher expressed similar comments regarding student access to personal audio technology. "Many of my students do not have access to computers or even the web for that matter the appropriate software or devices.”

Also is the issue of the economic status of our students. If I wish to distribute a CD they have no choice but to listen to it in the school. Many do not have web access at home so placing stuff on a web page would be useless.

While very little reference to infrastructure was noted, there is some concern as to the amount and consistency of bandwidth and its effect on using digital audio.

One high school teacher was extremely frustrated and commented that "The slow bandwidth in our common laboratory and in my classroom often causes disruptions in my teaching”. Four elementary teachers felt that having to teach at multiple locations presented a barrier to their expanded audio technology use. They acknowledged that having similar equipment in their two to five locations, however desirable, might never be achieved until well into the future. 
Figure 8. Recurring themes citing barriers to technology use by grade level.

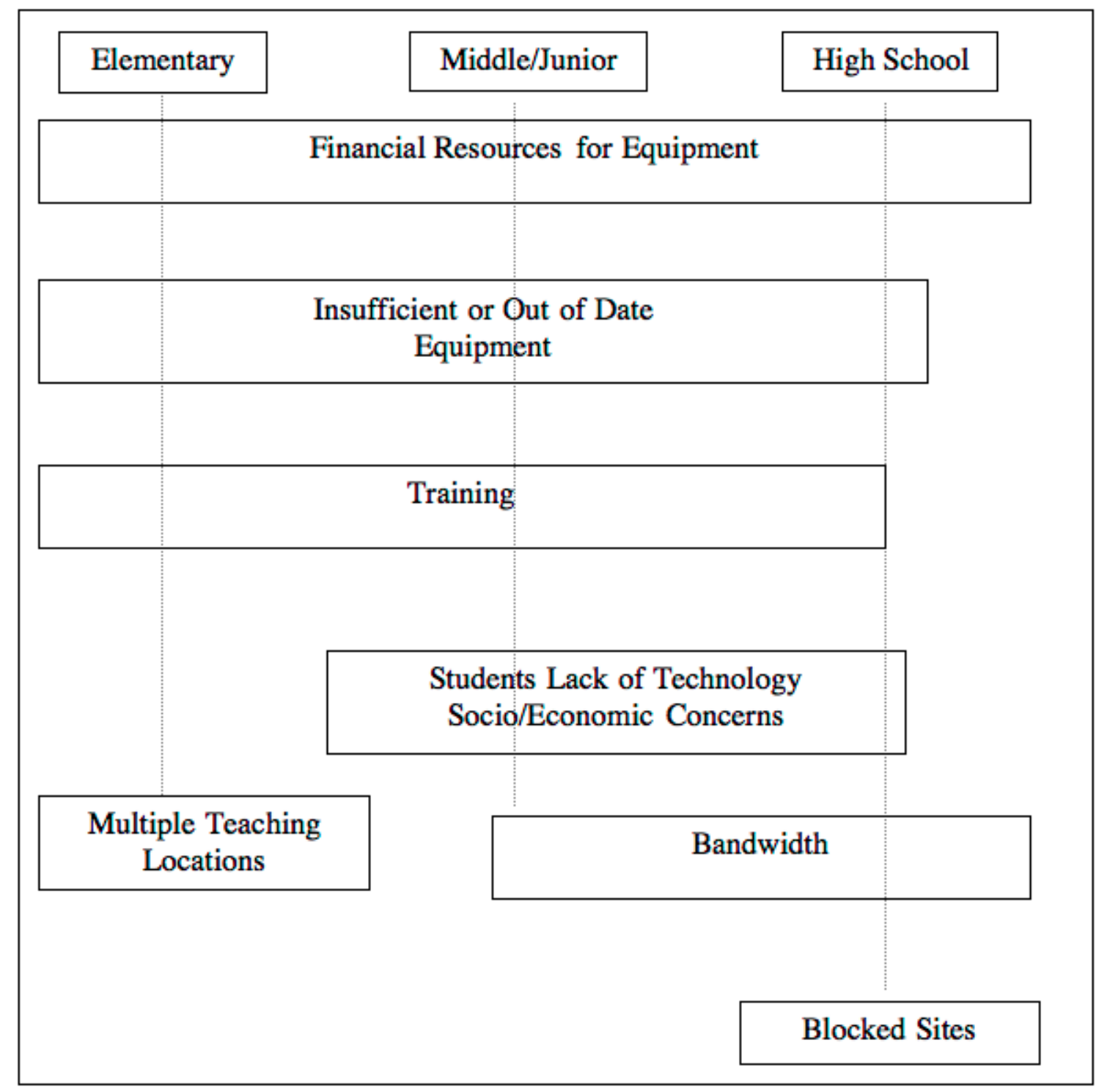

Skills. There was a clear hierarchy of recurrent themes when music teachers were questioned as to how they obtained skill in using digital audio technologies. Table 10 illustrates the frequency of keywords and phrases used within question 3 of the survey with contextual comments. The greatest frequency in response was an almost unanimous inclusion of acquiring skills through trial and error. Many music teachers believe that their technology skills are selftaught. Similarly, a significant majority credited their students for teaching them, often by 
indirect examples in the classroom. Many encourage experimentation by their students and then rely on them for determining the most efficient ways to incorporate utilization. Teachers who gained knowledge in using technology from their students believed that they still guided content and lesson focus.

The most positive formal instruction in audio technology was a result of corporately sponsored teacher workshops and training. One was a series of music notation demonstrations that were conducted throughout the state. While some teachers felt they would need additional instruction as a result of not currently owning the software, many found the content to be relevant to their teaching and inspirational towards adapting the software to their own use. The aforementioned adoption of a new music curriculum series resulted in positive experiences for many teachers. After adoption was recommended, many teachers were given the opportunity to work alongside corporate educational trainers towards integrating materials contained in the new series.

Peer tutelage was also a source of skill attainment for a little under half of the teachers. Those who had knowledgeable peers responded that it gave them a sense of security to know that someone could help them if they had a problem. It appears that like-minded peers encouraged and assisted each other with the results being increased motivation and success in using audio technology in engaging ways.

College course content and training was mentioned only in a negative light. When this theme appeared it invariable included secondary keywords of outdated, nonexistent, or not applicable or helpful in any way.

The remaining minority themes included family members as sources of learning new audio technologies. Few attended summer workshops but those that did so on their own 
initiative. There was a similar response when out of state conferences were included in the

commentary. Even fewer cited county level training as a viable source for obtaining skills. One teacher referenced training she had received while being employed in another state.

Table 10

Recurring themes and keywords within skill acquisition

\begin{tabular}{|c|c|c|}
\hline Key Word or Phrase & Frequency & Comments \\
\hline $\begin{array}{l}\text { Trial and Error / Self } \\
\text { Taught }\end{array}$ & $23 / 22$ & $\begin{array}{l}\text { "I am certain that } 75 \% \text { of my skill has been } \\
\text { obtained through trial and error." } \\
\text { "My own curiosity and self training has been the } \\
\text { primary source of my technology abilities." } \\
\text { "Definitely on my own. Of course I get some help } \\
\text { from my } 7^{\text {th }} \text { and } 8^{\text {th }} \text { graders." }\end{array}$ \\
\hline Students & 19 & $\begin{array}{l}\text { "My students definitely help more than my peers." } \\
\text { "I not only observe my students to obtain skills, } \\
\text { they give me very motivational ideas as to how to } \\
\text { apply the technology." } \\
\text { "Since they know what they are doing, I can push } \\
\text { them towards the musical concepts I want." }\end{array}$ \\
\hline $\begin{array}{l}\text { Software Company } \\
\text { Workshops }\end{array}$ & 12 & $\begin{array}{l}\text { "The Sibelius [Notation software] was the best!" } \\
\text { "The new series trainers did an excellent job. I felt } \\
\text { very comfortable starting the new series." }\end{array}$ \\
\hline Peers & 10 & $\begin{array}{l}\text { "My peers and the culture I associate with } \\
\text { continually helps me gain skill." } \\
\text { "My peers have been very helpful in helping me }\end{array}$ \\
\hline College Courses & 5 & $\begin{array}{l}\text { "Although the concepts are still valid, my college } \\
\text { technology course and the equipment is way } \\
\text { outdated" } \\
\text { "My undergraduate training was terrible" }\end{array}$ \\
\hline Own Children & 4 & $\begin{array}{l}\text { "If I need to know how to do something I asked my } \\
\text { kids" }\end{array}$ \\
\hline Summer Workshops & 4 & $\begin{array}{l}\text { "There some great workshops that I paid for out of } \\
\text { my own pocket" } \\
\text { "I was able to get some graduate credit and } \\
\text { beginning training going to a Technology Institute } \\
\text { course" [TI*ME] }\end{array}$ \\
\hline County Training & 2 & $\begin{array}{l}\text { "I would love an In-service with more applicable } \\
\text { content. I guess I have gotten some skill from the } \\
\text { few trainings we have had" }\end{array}$ \\
\hline
\end{tabular}

(table continues) 
Recurring themes and keywords within skill acquisition (Continued)

\begin{tabular}{lcl}
\hline \multicolumn{1}{c}{ Key Word or Phrase } & Frequency & \multicolumn{1}{c}{ Comments } \\
\hline $\begin{array}{l}\text { Out of State } \\
\text { Conferences }\end{array}$ & 2 & $\begin{array}{l}\text { "Often I will take a personal day when the } \\
\text { neighboring state is having a music conference. } \\
\text { Since they are bigger there is usually many more } \\
\text { sessions of my technology interest" }\end{array}$ \\
\hline $\begin{array}{l}\text { Training in Other } \\
\text { States }\end{array}$ & 1 & $\begin{array}{l}\text { "When I worked in Florida the state had a lot of } \\
\text { great technology workshops. They were really } \\
\text { relevant" }\end{array}$ \\
\hline
\end{tabular}

Research Question 4: What teaching decisions are made when using digital audio technologies and what impact do they have on student learning?

To assist in answering what effect digital audio technologies have had on teaching decisions and their impact on learning (RQ4) interview questions 4-7 were used (Appendix B). Additionally, these themes and conclusions were used to answer RQ 5 as well. Questions addressing specific audio technology methods, current decisions as opposed to previous teaching decisions, and the teachers assessment on how these technologies have helped students learn were used as guides.

Teachers' responses were quite specific when queried about the influence of digital audio technologies on their teaching methods. There was a very even distribution of two emergent themes. These were greater efficiency or flexibility in teaching, and a far greater amount of accessible musical material. Secondary comments addressed change or lack of change in teaching methodology. Efficiency in teaching was generally obtained by the use of direct digital audio technology use, either CD or digital files, use of MIDI files, use of an I-Pod or other MP3 player, digital recording, or using notation software. Teachers remarked that they are now free to move around the classroom and address individual students in a more timely fashion. Of the 24 
interviews, 22 answers contained at least one reference to using the aforementioned processes.

This is illustrated in Figure 9.

Figure 9. Digital technology uses by frequency of keyword.

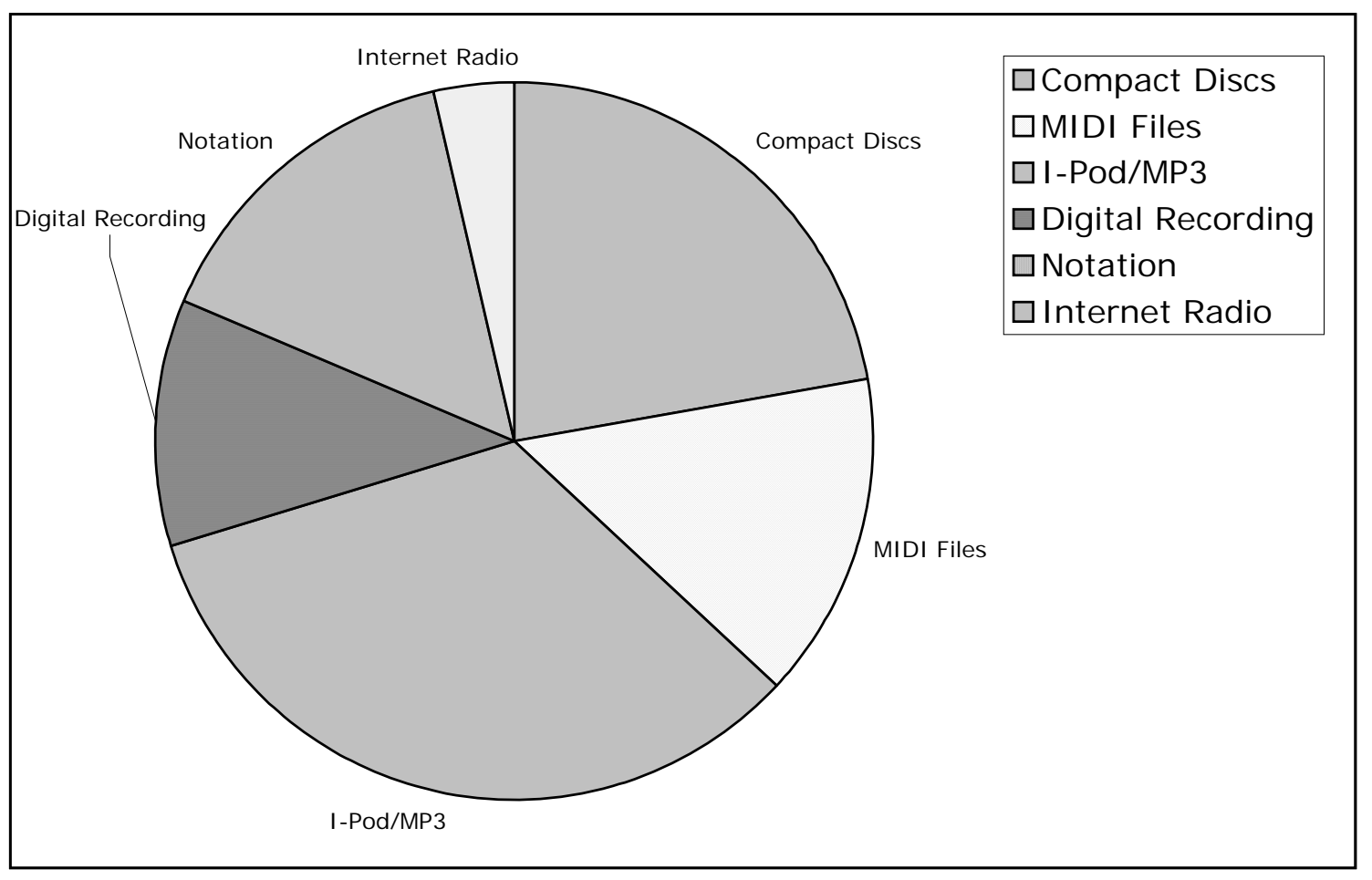

I-Pod use and compact disc use were the most frequently mentioned within interview answers. Comments from teachers representing all grade levels included:

I make accompaniment CDs for all of my performances. It frees me from sitting behind the piano and allows me to work directly with all of my students.

The iPod makes for a more dynamic environment. It provides a far better accompaniment tool.

I've used the iPod recording device to help my students analyze what they are doinghow they sound. I have recorded students who have made up songs and burned CDs for 
them

Often teachers cited more than one application, as was the case for this HS teacher of instrumental music:

It is far easier. I can provide CDs for the students. Everyone has their own files/audio clips on our website. They can download, print, or listen to a MIDI file. There is no more “I Lost My Music!” I can choose what to put on a CD...his or her own part, an accompaniment, or even a piano version of their part.

MIDI applications were put to an efficient use by this HS/MS Band Director who said:

I have to always remember that the kids are way ahead of us. These technologies have helped us plan curricula. Especially for marching band. They have save us a ton of money by never having lost parts, and kids can see other parts in the score. We can MIDI stuff and print it tailored to the student, class, or problem we wish to solve.

Digital recording processes and notation programs were also considered as changes in teaching methods. While the recording processes were rudimentary, using basic MP3 recording devices, the two most advanced notation programs were specified by two HS teachers:

SMARTMUSIC - has been helpful to encourage students at school to practice during study hall time. It also has given me a chance to evaluate the students’ progress without taking time out of instruction for individual playing tests. I can also create a Finale score and upload it into SMARTMUSIC so that the students can also practice the music not found in their method books.

FINALE , I use FINALE to create accompaniment tracks for choir. I save them as a midi file on a floppy disk and play them on my keyboard so that I am free to walk around the 
room and monitor progress. I can also burn a CD accompaniment or parts for students to practice with.

Access to Content. The wealth of available resources, especially digital audio files, was the second emerging theme. Several teachers expressed initially being overwhelmed with the “dearth” of material available on-line but a majority communicated an enthusiasm towards having access to more music. It was a general consensus among those who referenced content as a keyword that they were using far more materials than previous years. Comments included:

It has made me want to share more musical examples that I supplement with the students. I am tending to add more musical styles that I am passionate about.

They have given me endless resources for reaching the students. I can record my band or choir rehearsals on my MP3 and play it back to them so that they can self-evaluate their performance. I then usually play a professional recording I found on the net.

There is far greater accessibility to material, especially digital recordings. It is really easy. I utilize much more listening than before, especially "Pandora” [Internet Radio]. I use virtual music lessons by Web and CDROM for my advanced students.

Teaching methodology. Cognizant changes in educational philosophy were not evident as having been influenced as a result of the digital audio technologies. A minority (three) included this keyword within their answers. Teachers with 20 and 22 years teaching experience respectively expressed divergent views on the technology and their teaching methods. A third teacher with 16 years expressed her wishes for change as a result of technology influence. Their comments were: 
I am able to exploit the modalities. It encompasses visual, aural, and kinesthetic learners. I use much more scaffolding now. I start with their basic skills and move toward an ideology. I think better tools make better music/musicians.

I still teach the same way. Perhaps I have more resources available and maybe play/utilize more musical examples. I would love to utilize more self-assessment so I am more cognizant of what I perceive to be easier ways (as a result of technologies) to accomplish this.

I wish I had the ability to do everything from a computer based delivery system. I really have made an effort to take advantage of things like virtual concerts and alternate delivery systems.

Specific applications. An unexpected consequence of these answers was the specific information gained regarding brands, devices, and software being used. Table 11 indicates the type of process, quoted application(s), and frequency of response within the transcribed interviews. While this information might best serve to assist in answering RQ 2 it is included here due to relevance and context of the interview quotations. 
Table 11

Specific Applications Quoted in Interview Question 4

\begin{tabular}{|c|c|c|}
\hline Process & Application & Frequency \\
\hline \multirow[t]{3}{*}{ MIDI Sequencing } & Garage Band & 3 \\
\hline & Digital Performer & 2 \\
\hline & Logic & 1 \\
\hline \multirow[t]{2}{*}{ Digital Audio Source } & I-Tunes & 6 \\
\hline & Napster & 1 \\
\hline \multirow[t]{2}{*}{ Notation Software } & Finale (Make Music) & 5 \\
\hline & Sibelius & 5 \\
\hline \multirow[t]{3}{*}{ Digital Recording } & Garage Band & 2 \\
\hline & Audio Galaxy & 1 \\
\hline & I-Record & 3 \\
\hline Internet Radio & Pandora & 1 \\
\hline \multirow[t]{2}{*}{ MP3 } & I-Pod & 14 \\
\hline & Zune & 1 \\
\hline
\end{tabular}

Research Question 5: Has the use of digital audio technologies changed the teaching practices of WV public school music teachers?

Teachers were prompted to compare their teaching decisions using newer technologies to previous decisions made when using older technologies. The single most prevalent theme involved change in content and materials. The second recurring theme involved changes in planning for integration and use which weighed the benefits for the students as well as the 
teachers concerns. Planning also included infrastructure requirements. A third segment of answers reflected on change as it related to moving away from older audio technologies. Three key words could be found in a majority of responses which helped define the primary reasons for any change in teaching decisions. In order of frequency these were the ability to engage students, student benefit, and efficiency of use in the classroom.

Content and materials. Changes in content keywords and phrases mirrored the primary reasons for change. The only exception was a theme of the amount of new material available which made it worthwhile to use instead of previous materials. This permitted the selection and manipulation of lesson appropriate material at a far greater rate. Teacher responses which emphasized the key themes included two elementary teachers who found availability and ease of manipulation a significant asset:

Yes I love animated listening maps and the immediacy of digital recording playback. These materials and tools are far more available now.

I no longer have to rely on finding a CD track in my textbooks if I am looking to teach a specific listening example. I can download the song and burn it to a disk or sync it to a devise to play in class.

A string teacher balanced flexibility with efficiency and ease of selection of appropriate materials. Her remarks included:

I give my materials more scrutiny than before and am judicious in my use of materials. Especially since there are so many. I have the flexibility to pick and choose what I need very rapidly and efficiently. Both for planning lessons and on the spot exercises which solve problems in a lesson. 
A high school teacher continued to grapple with the change in materials and their availability. While expressing some frustration, he still encapsulated the fact that change in content has made a significant contribution to his teaching materials and delivery systems. He said, “Online materials are a far greater part when I can use them. There are many better alternatives which I would gladly always use but money is the factor. I feel like I teach with one foot in the past and one foot in the present. I certainly have incorporated virtual concerts as our rurality caused the kids to miss out on those types of experiences (Symphony On-Line). I have transferred some Orff music to digital which seems to be going well. It engages the kids and still allows me to use my older lesson plans (which I thought were effective).”

Efficiency. Specific examples of efficacy and efficiency as a result of new materials were obtained from several interviews. The remarks demonstrate the obvious adoption of new materials over older ones and reflect an enthusiasm towards the newer content. These remarks are encapsulated below as made by two high school teachers, a middle school teacher and an elementary teacher.

Creating files on Finale also allows me to adjust the tempo of the music so that students can sing to a slower accompaniment when learning parts.

When choosing music for this year's concert band, I chose music that was already part of the SMARTMUSIC for concert band so that I could track student's progress through SMARTMUSIC.

I relish the efficiency of digital technologies. I certainly do not bother with records or tapes anymore. 
The elementary teacher comments, "Yes, I have changed to a degree. When demonstrating with older technology it took a bit more (ha ha) time and patience to find listening examples at the library! The quality of the resources was not that great. I found myself spending most of my time teaching singing skills in general music because it was the easiest and didn’t require much to prepare. Now I have a ton of material which I can use for anything at anytime."

Planning. Decisions to implement digital audio technology referenced the use of the teacher's time and resources balanced with the benefit to the student. While these decisions might be applied to any teaching methodology, it is evident that decisions to implement audio technologies in a lesson have created a commonality in concerns and issues. These include preparation time, efficiency of class time, and the impact on students. Three extrapolations clearly delineate these teaching decisions.

Is this worth the prep time (to move any digital audio device to my room or take kids to a lab) on my part? Will it be effective and impact the student's learning? What is the cost to me? When do I implement this into the lesson?

When to use it, when not to. If the time it takes to record and replay is worth the results I may or may not get. (Can the students reasonably adjust their performance based on what they hear or am I recording and setting them up for failure?) I often consider whether hearing themselves will motivate the students or discourage them.

I need to plan when using the computer lab. Whether it is CDROM, Web Sites, audio requirements, and the like. Much of this has not been discussed with our lab coordinators. 
I need to identify what I am trying to accomplish musically before directing the kids. I also need to match the technology lesson with what we are trying to learn.

One middle school teacher is still struggling with his teaching decisions. His concerns are educationally founded and appear to be very valid in the context of wishing to use the technology and balancing what he wishes to do. His remarks included the following, "Because of the inability to utilize the technologies with everyone, it becomes an ethical decision. Do I utilize the technology just for special learners or my advanced students? Quite often I will choose not to use the technology because it takes up too much time and opens up more work for me. I do try to use everything I can. Everything out there is still a valid learning too. Often it is still a problem for engagements using many students. I do move away from the front of the classroom more as I can trust the newer digital and MIDI accompaniments to repeat at the touch of a button.” A minority theme reflected a sense of feeling force into using digital audio technologies within the content of lessons. A veteran middle/high school teacher remarked:

I now have to teach $21^{\text {st }}$ century learner principles which certainly could not be done using the older technology. Digital appears to allow engagement of many more students then, for instance, the old tape recorders. So I use them.

Changing from old to new. Music teachers who chose to discuss change in terms of their transitional experiences provided succinct descriptions of what they believed has transformed. Table 12 illustrates the change themes present in the interviews which compared an older technology or ideology with ones using digital audio technologies. Software choices, hardware choices, types of learners, teacher methodology and teacher expectations were evident themes. The frequency of these themes however was limited to only a fourth of all interviews. 
Table 12

Comparison of Older Technologies. Methodologies, and Expectations to the Present

\begin{tabular}{ll}
\hline \multicolumn{1}{c}{ Past } & \multicolumn{1}{c}{ Present } \\
\hline $\begin{array}{l}\text { "older equipment and software which is } \\
\text { more complex" }\end{array}$ & $\begin{array}{l}\text { "user friendly software and out of the box } \\
\text { equipment" }\end{array}$ \\
\hline "I used to have less expectation" & $\begin{array}{l}\text { "I have changed these expectations...now } \\
\text { there are no excuses. }\end{array}$ \\
\hline $\begin{array}{l}\text { "Recording with the old cassette tape } \\
\text { player resulted in a lot of hissing sound and } \\
\text { terrible quality" }\end{array}$ & $\begin{array}{l}\text { "Recording on a digital source allows for a } \\
\text { more clear result and is far more easily } \\
\text { manipulated" }\end{array}$ \\
$\begin{array}{ll}\text { "Previously I thought the students were } \\
\text { textbook/rote learners" }\end{array}$ & $\begin{array}{l}\text { "there are far more aural learners now than } \\
\text { those who ever learned from a textbook. } \\
\text { Results are quicker when they hear and see } \\
\text { it than when they read it" }\end{array}$ \\
\hline "Taught by example most of the time" & $\begin{array}{l}\text { "I am now definitely more a guide or } \\
\text { facilitator" }\end{array}$ \\
\hline
\end{tabular}

Perhaps the best comments were expressed by an 18 year veteran high school band director who said, "Previously my only focus was how could I teach the maximum children? It's now more teamwork than individual teaching. How can I expand or consolidate my instructional base. The kids are far more independent now. I can rely on this. The difficulty is in the community. What we used to believe is no longer the model. Nothing about school is the same. I am teaching differently but the outcomes are not accepted by the administrative perceptions of whether it is relevant.”

Student learning. The effects of digital audio technologies on student learning were answered in many positive and favorable comments. There was much diversity in these answers as many teachers converged their own learning with that of their students. As a result, while this convergent information might serve to answer other research questions, a general categorization 
of themes does emphasize that there has been an effect on students.

This impact included individual themes which were motivated learners, quicker learners, and more independent learners. The key themes identified were, once again, exposure to new materials and the variety of successful engagements with the musical material. Balancing these were the themes of opportunities to create and provide individualized instruction, and the receptiveness of the students towards digital audio technologies. The analysis revealed no negative comments towards any effect of the technology adversely effecting learning.

New materials. As in previous interview answers, teachers were quick to point out their believed benefits of exposure to a significantly greater amount of audio materials. Often it was their own access, which contributed to their knowledge base and utilization. This was illustrated by an elementary teacher who said that "I am able to expose my students to types of music that I was unable to utilize before. Digital technologies reach students so much more because they are more accessible to me as a teacher.”

Similarly, a veteran teacher was able to meld past experience with the present saying, "MP3s have made it easier for me and the students to have access to audio files. I am also pleased that older records have been re-released so I am able to use material that I have found effective in the past. It is sort of the same process with a new delivery and a whole bunch of options for material.”

The availability of audio material included references to how students reacted to the availability of a wider range of audio files. One middle school teacher relayed her experiences with MIDI saying "I love the access MIDI files provide. It serves anybody at anytime. Many of our kids now bring their own music to general music class. They never did this before.” Another teacher, of the same grade level, offered MIDI and digital audio source use in relation to their 
student's desires. This teacher even offered advice to other teachers. Her response was "Now, with my low-level or lazy-learner I can pare down every element we are working on. Using live recording and playback, MIDI playback, I can alter my support materials to the required level of the learner. Likewise I can add things for my advance learners. My total control as a result of the digital manipulation ease makes each student feel special. There are things my advance students have wanted to learn that I personally did not have the skill or experience to offer them. Now we learn together as resources are easier to find and present. Many audio examples, new sheet music, and interactive lessons are available now. You just have to find it.”

Engagement. While engagement has been a key theme throughout the interviews, when it came to learning, the types of engagements were varied. As is illustrated in the comments below, student's enthusiasm was generated by terms they were familiar with and the change in teacher delivery.

The effects on the students are tremendous, all you have to do is say any tech word like computer, MP3, or even "game” and they become engaged.

Students can experience concepts faster due to the technology for them to not only hear something but also see it as an audio/visual on a smartboard or computer. It takes far less time to point to a screen or monitor that walk around the room and point to each book. They love the interaction... or maybe the lack of me walking around.

An elementary/middle school teacher using audio technologies as a reward was very pleased. Her comments included the following:

I now use technology interactions as a reward. The personal CDs that I make are incredibly helpful. They love them and it becomes obvious who uses them. 
Other types of engagements included aural experiences and the immediacy of audio manipulation. The second commentary also reflects additional teacher benefit to their self education.

I think the most significant factor is that they have come to learn that what they hear individually in their head is not always what it sounds like.

Definitely, the ability to repeat and manipulate (control) audio is fantastic. It frees me up to address the students who are lost. When I can, I actually participate as a learner experiencing it with the student. It gives me a totally different light as to how they are learning.

Specific examples of success in student learning included very articulate descriptions of activities in the classroom. This was especially prevalent at the high school level where two teachers responded with the following:

This year, by using Garage Band [Sequencing Software] literally 10 students learned their solos with the accompaniments I tracked. They practiced and taught themselves. I believe all performed better and were ready for judging.

Aural skills have dramatically improved because of the freedom of individualized instruction. I can give immediate examples through recordings and in class recordings for direct comparison. Using the latter as guides.

Student receptiveness. Over half of the interviews contained commentary which reflected 
how students behaved when a digital audio technology was used in classroom instruction. The teachers were quite enthused by this and acknowledged that it was evident that students preferred/wanted their delivery system to include digital audio technologies. Of all of the interviews, the following illustrates the consensus among the teachers who responded using response to and personal identity with new audio technologies.

It's obvious that they respond to the visual and hands on aspects of any technology (whether it be software or a device). They become very excited and engaged.

It definitely keeps their attention. They expect all forms of multi-media, iPods, digital recordings of high quality.

Kids are visual and aural learners. They are accustomed to computers and MP3s. It really is almost all of them.

In a marvelous way the kids are more in tune as this is what they do.

Rejection of older technologies. Twenty-one of the twenty-four interviewees responded that there are no technologies they would never use. Of the three responding affirmatively, one indicated it was because of a poor experience in college with the aural qualities of ear training software and the other felt they simply did not have the ability nor time to learn the specific technology which referenced MIDI sequencing and MIDI keyboards. The third cited artistic reasons for auto accompaniment programs. The acknowledgement that students are diverse learners guided many comments which included using “older or more bizarre” technologies which, if "it engages them, so be it". A general philosophy presented was if any audio 
technology engagement works the teachers were willing to use it.

Reevaluation of teaching. Many teachers found that using digital music technologies resulted in them wishing they could be better teachers. This was a predominant theme when questioned whether they reevaluated their teaching as a result of digital audio technologies. Their comments reflected definitive change.

Absolutely, I have changed things every year. I now change more and more as more tools become available and I try to adapt (and adopt). I really always want to be a better teacher and it helps that the technology is stimulating me to be one.

Yes, I am constantly reevaluating. Even more now. Always looking to do things better.

Yes. I constantly change pacing and question when I should integrate or expose/utilize the technology. It definitely effects lesson flow. I question if it is distracting the students or throwing them off.

Everyday of my life. I find out what is going on and it changes me daily. I need to get used to students turning in work via Finale Notebook and MIDI.

Yes. I am trying to meet the state requirements. I constantly ask myself "How can I teach this differently" using my new tools, than in the past.

A secondary theme was the belief that these technologies allowed them to solve problems that they could not solve before. Problem solving was a relevant theme in responses for the reason why teachers had examined their teaching methodology. 
They have made teaching simpler in some ways. Rather than trying to describe what I hear, I can play it for them and they hear it much better

If I get stuck or in a jam I know that there is a solution out there. It falls on me to research it, learn it, and fix it.

The third theme was one of feeling relevant as a teacher. The most concise comments addressed appearance of relevancy in regards to reaching their students, and meeting standards. I do not want to appear old. All of this is second nature to the kids. If you want to teach them then you have to find the way to teach them right.

New audio technology has presented me with many up to date ways of reaching my students. Many times my students are more tech savvy that I am. If I can find a way to reach their "level” than I feel like I am keeping up with them, and maintaining their interests.

\begin{abstract}
Absolutely I have changed, I have changed things every year. I now change more and more as more tools become available and I try to adapt (and adopt). I really always want to be a better teacher and it helps that the technology is stimulating me to be one.
\end{abstract}

Yes. I am trying to meet the state requirements. I constantly ask myself "How can I teach this differently" using my new tools, than in the past. 
A minority of respondents felt that they have not reevaluated their teaching as a result of the emergence of new digital technologies. They were succinct in their comments, believing that a teacher should always reevaluate their teaching with one stating "It should be a constantly changing attitude and environment.” Others responded less definitively, stressing learning as a priority, such as the one teacher who said, "I really should investigate CDROM acquisitions for the computer lab, as the web sites do not permit constructionist teaching. We cannot save or build on previous projects”.

Assessment. Those who indicated a change in assessment methodologies as a result of digital audio technology often expressed disappointment in student outcomes. Their expectations include far greater student results when using digital audio technologies. Based on response, eight of the respondents indicated a move towards change or having changed their assessment methodologies. While the number of teachers who indicated no change was significant, many included commentary which leads to their intent of some sort of new assessment mechanism via technology assimilation. Table 13 provides a summary of the primary quotations representative of change, moving toward change, and effective change.

Table 13

Commentary Regarding No Change, Slight change, and Significant Change of Assessment

\begin{tabular}{lll}
\hline \multicolumn{1}{c}{ No Change } & \multicolumn{1}{c}{ Moving Towards Change } \\
$\begin{array}{l}\text { No, my standards have } \\
\text { remained the same }\end{array}$ & $\begin{array}{l}\text { Not yet. I plan on using } \\
\text { both student submissions } \\
\text { (via web) and recorded } \\
\text { No. Technology has been } \\
\text { status quo within my } \\
\text { teaching experiences. It } \\
\text { really is just a part of what I I } \\
\text { have been doing. }\end{array}$ & $\begin{array}{l}\text { I think I assess more } \\
\text { effectively and differently, } \\
\text { as I am not stuck behind the } \\
\text { piano. I move around the } \\
\text { outcomes and expectations } \\
\text { are the same. I still apply } \\
\text { rubrics to outcomes but am } \\
\text { looking forward too more } \\
\text { content to evaluate when } \\
\text { using the technology. }\end{array}$ \\
\hline
\end{tabular}


Commentary Regarding No Change, Slight change, and Significant Change of Assessment

(Continued)

\begin{tabular}{|c|c|c|}
\hline No Change & Moving Towards Change & Significant Change \\
\hline $\begin{array}{l}\text { Outcomes are not different. } \\
\text { I am often disappointed is } \\
\text { the outcome is less because } \\
\text { the students have more } \\
\text { avenues to acquire the } \\
\text { skill/knowledge. }\end{array}$ & $\begin{array}{l}\text { I am just starting to work } \\
\text { with assessment in a bit of a } \\
\text { different way than before as } \\
\text { a result of some digital } \\
\text { technologies. Assessment is } \\
\text { my weakest link in teaching } \\
\text { and I am still working on } \\
\text { this, so yes I am looking at } \\
\text { the assessment outcomes } \\
\text { differently. }\end{array}$ & $\begin{array}{l}\text { I believe my expectations } \\
\text { and standards for } \\
\text { assessment have increased. } \\
\text { They should have better } \\
\text { retention, more } \\
\text { engagement, and certainly } \\
\text { more enthusiasm. }\end{array}$ \\
\hline
\end{tabular}

Not really. Often I will observe the kids figuring out how to use some technologies for their musical use. I welcome the ability to really dissect a performance or composition. If these tools are useful, fine, but assessing the outcomes, or actually the outcomes and expectations have remained the same.
I still observe and listen. I do a portfolio and am planning to have digital audio examples within the submissions. My expectations might be a bit higher but my assessment procedure remains the

The most significant affirmative response in regards to changes in assessment came from a middle school teacher who said, "This is the primary use of audio technology in my experience. Even as the teacher in the front of the room, I have always known that what I think I am hearing is not necessarily what is objectively going on. The use of audio technology has given me a more objective ear in my own teaching.” 


\section{Observations}

Four observations of using applications of digital audio technologies to teach music were made using a base criteria delineated in the outline for observations which is included in Appendix C. Notes and follow up questions were taken and compared for elements needed to answer RQ 4 and RQ5. Teachers and activities observed were selected as a result of participation in the previously analyzed personal interviews. Three classroom lessons were observed which included a middle school choral rehearsal, a group instrumental lesson for fifth grade string students, and a grade three general music class. A high school teacher who used the Internet and World Wide Web to disseminate instructional materials and audio examples facilitated the fourth observation. A synopsis of each observation has been provided below.

\section{Observation 1}

The first observation was of a seventh grade choral rehearsal. The teacher had integrated a process by which the students learn music and then record themselves. The recording is listened to in class where verbal and vocal comparisons and comments are made. The process continues throughout the allotted rehearsal time. The teacher utilized both direct instruction and used the recording as a model to improve results of the prepared pieces. At no time did the recording device impede the flow of the rehearsal or distract the students from the primary lesson objective. The primary focus of improving individual and group parts was obviously enhanced by the students' aural assessment of what they had sung. Individual students took responsibility for manipulating the recording process and playback. The students wanted to continue with repeated listening but once the musical point was made, the teacher continued moving the lesson forward. While the teacher believed the use of digital audio recording was very successful in terms of learning and improvement of performance, she was frustrated by the lack of time to 
“take it to the next step”. Her desires were to be able to post, on the Internet, the in-class recordings or disseminate them via compact disc so that the students might continue to assess themselves.

\section{Observation 2}

The second observation was of a group applied music lesson for violins. The students were positioned in a semi-circle with the teacher and lap top computer with speakers was in the center. Students modeled what they heard from the digital audio examples, performed individually and together for the teacher, and then performed with digital audio accompaniment coordinated by the teacher using the computer. While the technology played a prominent role in the students' interaction, the primary focus was producing the correct pitches and rhythms on their instruments. Any commentary regarding mistakes or difficulty was actually directed at the computer or accompaniment, not the teacher. She just continued to modify the content by shortening or lengthening examples and changing tempo to ensure success and then challenge each student. The teacher also accessed different musical examples to solve individual problems when they became evident. A post observation remark included the availability of standard exercises "stored on my hard drive" to reinforce persistent common problems when they might arise. The students obviously became enthused when the teacher changed tempo or rhythmic accompaniment and were motivated by the timbral quality of the accompaniments and examples. The teachers also added that she was using a mixture of new materials and older, which she had converted to digital format, as these material had proven successful in the past and she wanted to continue using them. 


\section{Observation 3}

A grade three elementary general music class was visited for the fourth observation. The objective of the lesson was musical form and rhythm. The teacher had integrated audio CDs for listening examples, an animated video/audio listening map, and a MIDI instrumental accompaniment with standard singing and movement activities. The lesson includes direct instruction, modeling, and interactive learning. All of the activities related to the primary lesson objectives and supported each other. The students seemed accustomed to the use of the iPod as a source for their listening and initial accompaniment experiences. Once modeled and removed, they were able to sing independently and with the correct pitch and rhythm. The animated listening map contained enhanced audio materials which engaged the students. The teacher had prepared a MIDI accompaniment with different audio characteristic as a culminating exercise. The students were permitted to manipulate this material by taking turns starting, stopping, and repeating the material using a MIDI keyboard. It was very obvious that they were engaged. Some time was wasted finding appropriate audio files, specific audio "tracks”, and waiting for the keyboard to load files. This did not appear to distract from the learning environment. The teacher used a remote control so they could move around the classroom and still control audio volume and location of the examples. The students consistently asked the teacher to repeat the digital audio engagements with the listening map and MIDI accompaniment(s).

\section{Observation 4}

At the recommendation of an experienced high school music teacher, this observation was of an instrumental ensemble web page. The page was designed to disseminate copies of music that the students were working on, audio examples of the individual parts and ensemble parts, and digital audio recordings made previously in the classroom and placed on the web for 
student listening and assessment. The page also contained links to many music education web pages for student development but this was not the primary reason. Based on the number of "hits” via a counter embedded on the web page it could be considered facilitating learning albeit indirectly. Audio files were being disseminated in a standard format but were being referred to as a "Podcast". This was a result of the teacher converting a Podcast format (RSS Feed) to a traditional digital audio format (QuickTime). According to the teacher, this was because of either county or state infrastructure issue in regards to types of access allowed and types of materials. It was mentioned that the state either recommends as an objective or requires RSS feeds (podcasts) but such feeds are not allowed. The researcher did not confirm this. The teacher also reported that many students continually checked for new material on the page and were enthusiastic when additions were made. The teacher reported that this is now a monthly activity for him and that he wishes he could update more often. A summary of observation notes used to answer RQ 4 and RQ 5 is included in Table 14.

Table 14

Summary of Observations

\begin{tabular}{|c|c|c|c|c|}
\hline & $\begin{array}{l}\text { Grade } 7 \\
\text { Choral } \\
\end{array}$ & $\begin{array}{l}\text { Group Lesson } \\
\text { Grade } 7\end{array}$ & $\begin{array}{c}\text { Elementary-General } \\
\text { Grade } 3 \\
\end{array}$ & $\begin{array}{l}\text { High School } \\
\text { Web Page }\end{array}$ \\
\hline $\begin{array}{l}\text { Teaching } \\
\text { Strategy }\end{array}$ & $\begin{array}{l}\text { Direct and } \\
\text { Indirect }\end{array}$ & $\begin{array}{l}\text { Modeling and } \\
\text { Interactive }\end{array}$ & Direct and Interactive & $\begin{array}{l}\text { Indirect and } \\
\text { Facilitating }\end{array}$ \\
\hline Focus & $\begin{array}{l}\text { Indirect student } \\
\text { technology use, } \\
\text { assessment }\end{array}$ & $\begin{array}{l}\text { Performance } \\
\text { improvement }\end{array}$ & $\begin{array}{l}\text { Integrated with } \\
\text { traditional } \\
\text { methodology (same } \\
\text { focus) }\end{array}$ & $\begin{array}{l}\text { Material } \\
\text { access as a } \\
\text { result of } \\
\text { technology } \\
\text { interaction }\end{array}$ \\
\hline $\begin{array}{l}\text { Support of } \\
\text { Objectives }\end{array}$ & Prominent & Prominent & $\begin{array}{l}\text { Balanced with } \\
\text { traditional pedagogy }\end{array}$ & $\begin{array}{l}\text { Prominent as } \\
\text { a result of } \\
\text { access }\end{array}$ \\
\hline
\end{tabular}

(table continues) 
Summary of Observations (Continued)

\begin{tabular}{|c|c|c|c|c|}
\hline & $\begin{array}{l}\text { Grade } 7 \\
\text { Choral }\end{array}$ & $\begin{array}{c}\text { Group Lesson } \\
\text { Grade } 7\end{array}$ & $\begin{array}{c}\text { Elementary-General } \\
\text { Grade } 3\end{array}$ & $\begin{array}{c}\text { High School } \\
\text { Web Page }\end{array}$ \\
\hline $\begin{array}{l}\text { Teacher } \\
\text { Comfort }\end{array}$ & $\begin{array}{l}\text { Student } \\
\text { operated under } \\
\text { teacher } \\
\text { guidance }\end{array}$ & $\begin{array}{l}\text { Controlled all } \\
\text { engagements } \\
\text { and modified } \\
\text { to solve } \\
\text { problems }\end{array}$ & $\begin{array}{l}\text { Some time issues } \\
\text { regarding finding } \\
\text { audio materials }\end{array}$ & $\begin{array}{l}\text { Developed } \\
\text { and managed } \\
\text { by teacher }\end{array}$ \\
\hline Facilitation & $\begin{array}{l}\text { Allowed } \\
\text { students to } \\
\text { operate }\end{array}$ & $\begin{array}{l}\text { Kept in reach } \\
\text { and modified } \\
\text { while students } \\
\text { engaged } \\
\text { w/other } \\
\text { material }\end{array}$ & $\begin{array}{l}\text { Used remote control } \\
\text { to allow for } \\
\text { individual attention }\end{array}$ & $\begin{array}{l}\text { Trouble with } \\
\text { Podcast } \\
\text { formats. } \\
\text { Teacher } \\
\text { changed }\end{array}$ \\
\hline $\begin{array}{l}\text { Reactions } \\
\text { And } \\
\text { Adjustments }\end{array}$ & $\begin{array}{l}\text { Wanted } \\
\text { repetition. } \\
\text { Teacher moved } \\
\text { on once concept } \\
\text { was clear. }\end{array}$ & $\begin{array}{l}\text { Students } \\
\text { responded } \\
\text { well. Wanted } \\
\text { more } \\
\text { variations } \\
\text { controlled by } \\
\text { teacher to } \\
\text { tempo and } \\
\text { rhythm }\end{array}$ & $\begin{array}{l}\text { Students engaged. } \\
\text { Teacher repeated at } \\
\text { student request. }\end{array}$ & $\begin{array}{l}\text { Many users. } \\
\text { Students } \\
\text { check for } \\
\text { updates. }\end{array}$ \\
\hline Success & $\begin{array}{l}\text { Much, wanted } \\
\text { more time for } \\
\text { follow up }\end{array}$ & $\begin{array}{l}\text { Yes, } \\
\text { especially } \\
\text { melding old } \\
\text { and new } \\
\text { materials }\end{array}$ & $\begin{array}{l}\text { Students were very } \\
\text { responsive, even } \\
\text { when not using } \\
\text { technology as a result } \\
\text { of mixture and } \\
\text { pacing }\end{array}$ & $\begin{array}{l}\text { Now } \\
\text { considered a } \\
\text { monthly } \\
\text { requirement }\end{array}$ \\
\hline
\end{tabular}

Summary of Analysis

The survey (Digital Audio Technologies for Teaching and Learning) was used to obtain a mixture of nominal and ordinal data. This data was used to answer RQ1, RQ2, and RQ3. Oral interviews, following a standardized open-ended question format, contributed to answering RQ3, RQ 4, and RQ5. Classroom observations were utilized to observe teachers' use of digital audio technologies in context of teaching. The four observations contributed to answering RQ 4 and 
RQ 5. Interview and observation elements provided the basis for comparison analysis using the emerging themes gained in the individual interviews. Questions one thru eight of the survey answered RQ1 and were analyzed by frequency of response. This included information pertaining to demographic information including years of experience, discipline(s), and education. The next four sections of the survey answered RQ2. Data analyzed by frequency of response was the use of audio formats, digital audio devices, digital audio activities, and audio software.

As a result of comparison analysis, an emergent theme within the individual interviews also contributed in answering the RQ. Both survey questions and interview themes were used to answer RQ3. Quantitative data was examined to determine the extent of skill and confidence in the teachers’ knowledge and use of digital audio technologies. Four main areas which were comfort level in learning, contribution to use, barriers to use, and skill acquisition guided interview questions. The analysis revealed three key areas which became the primary contributions in answering the RQ. These were finances, equipment, and training.

RQ4 was answered by an analysis of the final survey questions, personal interview themes, and classroom observations. Survey data revealed sources of knowledge attainment, reasons for using digital audio technologies and incorporation of the audio technologies into planning and teaching lessons. Interview answers were guided by themes of specific methodologies, differences in current decision-making, and assessment. The analysis yielded five primary key words, which were used to answer RQ4. Classroom observation data was also used in the analysis. RQ 5 was answered by an analysis of emergent themes in personal interviews and by an examination of classroom observation notes. Digital audio technology’s influence on teaching, success or failure, and the teacher's view of content guided the analysis 
resulting in five key areas that were used in answering the RQ. A summary of the data sources for each research question is depicted in Table 15.

Table 15

Summary of Data Sources and Data Analysis

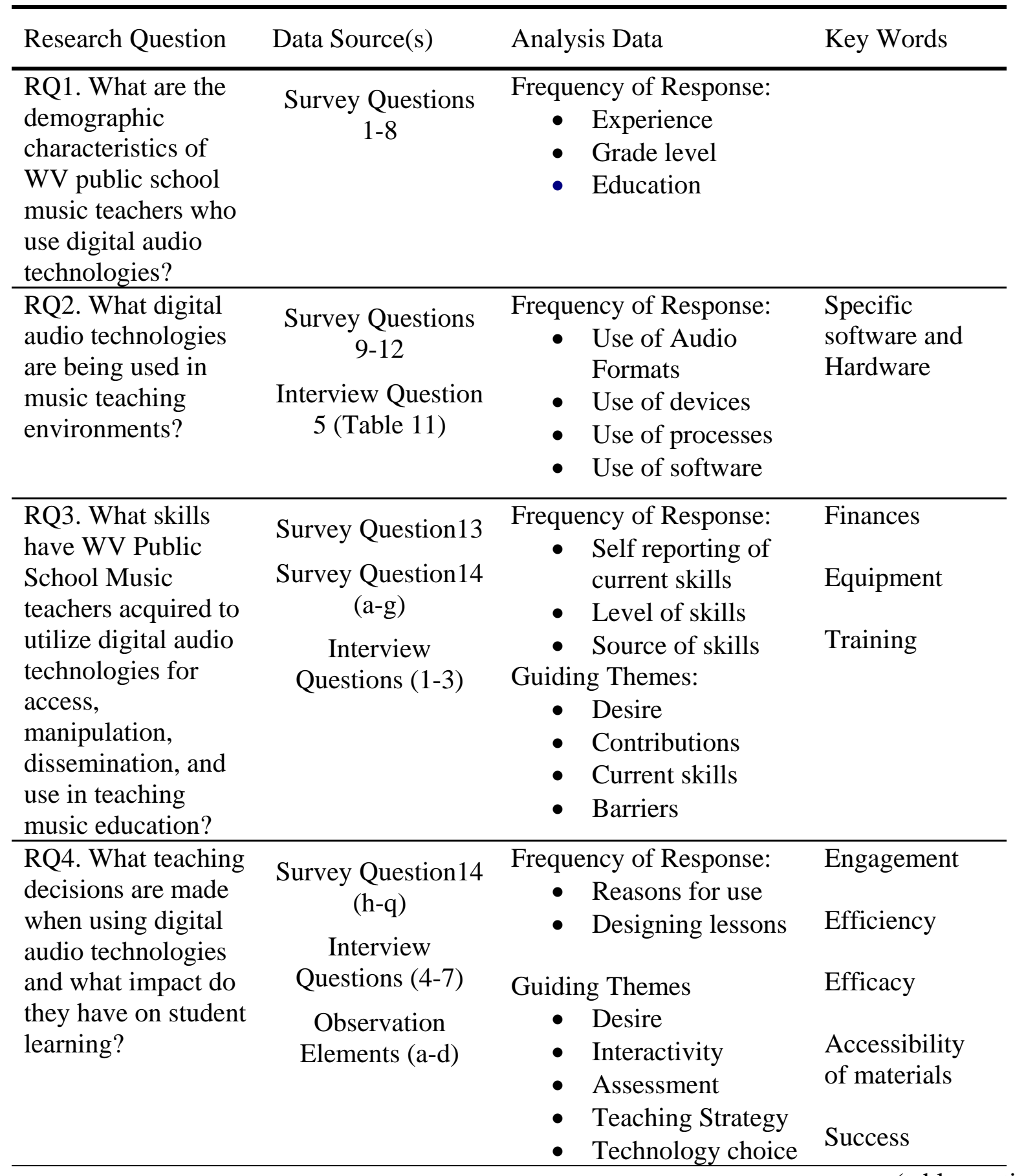


Summary of Data Sources and Data Analysis (Continued)

\begin{tabular}{|c|c|c|c|}
\hline Research Question & Data Source(s) & Analysis Data & Key Words \\
\hline $\begin{array}{l}\text { RQ5. Has the use of } \\
\text { digital audio } \\
\text { technologies } \\
\text { changed the } \\
\text { teaching } \\
\text { practices of WV } \\
\text { public school music } \\
\text { teachers? }\end{array}$ & $\begin{array}{c}\text { Interview } \\
\text { Questions (4-10) } \\
\text { Observation } \\
\text { Elements (e-g) }\end{array}$ & $\begin{array}{l}\text { Guiding Themes } \\
\text { - } \quad \text { Influence on teaching } \\
\text { - } \quad \text { Success/Failure } \\
\text { - } \quad \text { Teacher view of } \\
\quad \text { Content }\end{array}$ & $\begin{array}{l}\text { Engagement } \\
\text { Efficiency } \\
\text { Efficacy } \\
\text { Accessibility } \\
\text { of materials } \\
\text { Student } \\
\text { response }\end{array}$ \\
\hline
\end{tabular}

Summary of Findings

Three methods of data collection were utilized, including a survey instrument, interviews, and classroom observations. These data sources were used in combination to provide verifiable data and a method that would effectively answer the research questions. Data to support the findings used to answer RQ1 was obtained from the Digital Audio Technologies for Teaching and Learning survey. A summary of the findings to answer RQ1 is shown in Table 16.

Table 16

Research Question 1 Summary

RQ1: What are the demographic characteristics of WV public school music teachers who use digital audio technologies?

Survey Data:

- Mature workforce with over half having ten years or greater teaching experience

- Less than half have pursued formal study beyond the bachelors degree

- No implications based on geographic location or years of teaching 
- Majorities have or are teaching "General” music. "Choral "and "Instrumental” music represented half of the respondents

- Greater than one-third of respondents teach at more than one school

Data to support the findings used to answer RQ2 was obtained from the Digital Audio Technologies for Teaching and Learning survey and personal interviews. A summary of the findings to answer RQ2 is shown in Table 17.

Table 17

Research Question 2 Summary

RQ2: What digital audio technologies are being used in music teaching environments?

Survey Data:

- Very little use of records or cassettes with CD audio format being the most preferred. MP3 formats follow.

- Very little use of DAT, Internet streaming or Internet radio.

- Majority do not use MIDI based keyboards or files

- Computer use in teaching acknowledged by $75 \%$ of all teachers responding

- CD Duplication is prevalent with over one third of teachers reporting use

- Most teachers used wired playback as their aural source

Interview Data:

- Many use iPods (as a result of new curriculum series) and some have begun using online procurement of audio materials (I-Tunes)

- Notation software, regardless of brand, is being utilized in several instances

- Those who use MIDI sequencing software use the most popular

- There are some individuals using digital audio recording devices 
Data to support the findings used to answer RQ3 was obtained from the Digital Audio Technologies for Teaching and Learning survey and personal interviews. A summary of the findings to answer RQ3 is shown in Table 18.

Table 18

Research Question 3 Summary

RQ3: What skills have WV public school music teachers acquired to utilize digital audio technologies for access, manipulation, dissemination, and use in teaching music education?

Survey Data:

- Strongest in manipulation of CD audio files

- Equally split in skill level of downloading MIDI and MP3 Files

- Over one third have not tried downloading or manipulation of MIDI and audio files

- More than half never tried podcasts, Internet radio or recording of Internet streaming

- Largest percentage never tried using DAT technologies

- Instruction by students, and instruction by peers are primary sources of skill attainment

- Formal training not considered a significant source for skills

- Weak in areas of designing lessons and planning strategies 
Research Question 3 Summary (Continued)

RQ3: What skills have WV public school music teachers acquired to utilize digital audio technologies for access, manipulation, dissemination, and use in teaching music education?

Interview Data:

- Do not want to be left behind thus seeking new skills

- Belief in the creative possibilities available motivates the teacher to learn new skills

- Availability of significantly more materials on the Internet and the strongly interactive nature of digital audio technologies contributed to teacher use

- New materials and devices via the newly adopted curriculum pushing teachers towards implementation

- Funding viewed as inadequate, with strong concerns over out of date equipment and lack of training causing lack of skill attainment

- Secondary barriers included students personal access to technology, bandwidth, infrastructure, and state policies towards site and application use

- Majority feel they are self-taught

- Corporate sponsored trainings rated highly

- Like minded peers supported each other

- Student instruction was welcome but teachers were cognizant of staying "in control"

Data to support the findings used to answer RQ4 was obtained from the Digital Audio Technologies for Teaching and Learning survey, personal interviews, and observations. Personal interviews revealed themes of flexibility, efficiency, access to content, and teaching methodology. Observations centered on overall strategy, the focus of using digital audio technologies, and teacher or classroom support for the engagement. A summary of the findings to answer RQ4 is shown in Table 19. 
Table 19

Research Question 4 Summary

RQ4: What teaching decisions are made when using digital audio technologies and what impact do they have on student learning?

Survey Data:

- Used to meet Content Standards and Objectives

- Half reported they could create materials to enhance student learning

- Support of student centered activities

Interview Data:

- Sought efficiencies as a result of quicker access to materials, and materials which permit immediate repetition, playback, or are easily configured to address individual problems

- Chose to use flexible software applications to provide benefits of directed study or to free up teacher to work directly with students

- Judicious use of an abundance of materials with decisions being based on potential for engagement with students

- Using many more audio examples

- While methodology has not changed, teachers are embracing the wealth of new materials and engagement possibilities as a result of digital audio technologies

Observation Data:

- Immediate distribution of desired content with numerous opportunities to model and then direct student learning

- Interactivity the key for classroom based activities

- Student centered focus for groups and individuals

- Engagements are initially implemented by the teacher with the teacher 
- Modifying any content where appropriate

- Concerns with access to sites which disseminate materials such as podcasts or public domain video.

- Teachers were quite confident in using digital audio engagements but also wary of things going wrong

Data to support the findings used to answer RQ5 was obtained from personal interviews and observations. Commentary addressed planning, transition to newer technologies, materials, student learning, and student receptiveness. Similarly, content, student reactions, and teacher adjustments were elements within the observations. A summary of the findings to answer RQ5 is shown in Table 20.

Table 20

Research Question 5 Summary

RQ5: Has the use of digital audio technologies changed the teaching practices of WV public school music teachers?

Interview Data:

- Selection and manipulation of materials at a far greater rate with alternative material consideration strongly considered to accomplish objectives

- Many distributing audio and lesson materials customized for students

- Promoting utilization as a result of enthusiasm and the ease and immediacy of access provided by the digital format

- Much more cognizant of infrastructure requirements, preparatory time required, and number of students reached when choosing to integrate a digital audio application

- A belief that the "new" students" are aural and visual learners

- Teachers are serving in a more facilitative role as a "guide" 
- Students are more motivated and engaged when digital audio technologies are used, thus the teacher wishes to use them

- The opportunities for increased individual directed engagements have proven beneficial

- Using many more audio examples because of accessibility, potential for spontaneity, and ease of blending with older materials

- Students are eager, motivated, and immediately engage with the materials presented, thus the teachers are seeking to use digital audio technologies

- Teachers held the philosophy that any technology based engagement was worthwhile

- While utilizing digital audio technologies the teachers feel more relevant to the student and have not lost sight of primary goal to reach the students

- Expectations have heightened though methodology though assessment has not

Observation Data:

- Teachers facilitated the digital audio technology applications by using a variety of instructional methods including direct instruction, modeling, interactivity, and self-discovery

- Many students manipulated the technology and exhibited a high level of enthusiasm and engagement

- Developed materials stored for later access while previously created materials used for review

- All deemed their engagements as a success while expressing desires to modify, improve, or continue the experience 


\section{Chapter 5}

\section{Conclusions, Implications, Future Research}

The purpose of this study was to identify which digital audio technologies are currently being used by WV music teachers, what influenced the technology use, what was the effect on learning, and what were the barriers to preventing more teachers from incorporating the technology. Participants were full-time Certified Public School Music Teachers currently teaching music in Grades K-12 in the State of West Virginia. Data for the study came from an online survey instrument, interviews and classroom observations taken between May 2008 and January 2009. The surveys provided numerical data while the use of narratives provided breadth and depth of what, how, and why the teachers utilized digital audio technologies. Data analysis and coding were used to draw meaning from the data and cross-case analysis provided verification of findings. Chapter five discusses the conclusions of this research and follows with a summary of findings, implications of the results, and suggestions for further research.

\section{Research Questions}

Research question 1: What are the demographic characteristics of WV public school music teachers who use digital audio technologies? The music teachers represented in this research are very experienced with over half having taught ten years or greater. Their grade levels and areas of instruction were quite diverse and reflected the staffing requirements found in most public school systems. Generalists were the greatest number and this number declines as the teachers reported increased specialization. Greater than a third of the WV music teachers participating taught multiple subjects with the predominant pairing being general music and choral instruction. Nearly a third are teaching at multiple schools. A majority has elected not to participate in additional formal study beyond the bachelor degree. There was no indication of any correlation 
based on neither RESA location nor subject area taught though the largest amount of respondents came from RESA areas which serve the highest population base.

Research question 2: What digital audio technologies are being used in music teaching environments? It is clear that the migration from records and cassettes to compact discs has been fully implemented. This migration is continuing towards digital file formats such as MP3 format. The data indicated that music teachers are beginning to explore frequent use of audio files within their classrooms. Digital audio tape, which is an older digital technology, was rarely used if at all. The newest audio formats, Internet streaming and Internet radio in particular, had little or no adoption as well.

While music teachers are using electronic keyboards in their classrooms, it is apparent that they are not using these devices to their capacity. MIDI functions (using a keyboard) as well as MIDI tone modules and MIDI interfaces are seldom used. Computer use with digital audio applications was utilized by three fourths of the teachers. This was the greatest use of any audio device. Advanced computer audio techniques, which included both CD and DVD "burning," were seldom used for music teaching. Use of an iPod or other MP3 player showed a slight adoption for classroom use.

Music teachers have been creating customized compact discs. This process appears to have become common practice for use in the classroom environment but not for any other type of dissemination. A very rare occurrence of using the Internet to disseminate digital audio information of any type was reported. Similarly, very few teachers create their own MIDI files. Interactive CD-ROMs are seldom used. As noted, the primary source of audio material for use in the classroom was from compact discs. The data indicates that very little of this material is obtained from commercial music outlets, public domain sources, or file sharing. It can then be 
assumed that music teachers are predominantly using compact disc audio material which was purchased by them or provided for them as an included component of their basal text curriculum series. There are indications that some swapping of audio material takes place. The use of on-line commercial audio stores is emerging as a source of material as the data indicated.

The most prominent digital audio software was CD duplication software. This validates the earlier results when placed in context to the number of teachers creating CDs for classroom use. The second most used software program is in the area of music notation. These packages contain audio samples, thus, teachers indicated their use of digital audio sample within their teaching. The use of internal computer sounds as primary software utilization corresponds to those who reported using a computer in their music classroom. There is not frequent use of MIDI software, digital recording software, or software instruments. Another significant result is the evidence that nearly half of the music teachers do not use or rarely use a computer in their instruction.

Research question 3: What skills have WV public school music teachers acquired to utilize digital audio technologies for access, manipulation, dissemination, and use in teaching music education? Music teachers feel most skilled in using audio CDs and manipulating or creating CDs from audio sources. While many express skills in the use of CD-ROMs in the classroom, previous conclusions show that they do not use them. There is a distinct divide regarding skills in downloading material from the Internet and other more advanced applications. While a minority of teachers expressed advanced skill in downloading material, nearly half of the music teachers have never tried the process. WV music teachers have not capitalized on the trends of Internet based materials for teaching and learning as first reported by Waters (1999) and later discussed by Webster (2002). Similarly, with slightly more than a fourth of the teachers 
feeling skilled in MIDI or MP3 applications more than half have never tried the process. This dichotomy carried through to MIDI file creation and audio editing functions. A majority of the music teachers have never tried subscribing to a podcast, using Internet radio in the classroom, or recording Internet streaming of audio material. Further lack of involvement was directed towards using a DAT recorder.

To obtain these skills, the survey data slightly contradicted interview data. Responses from the survey showed that half of the teachers received instruction from their students and to a lesser extent from summer workshops and self-instruction. A primary result of interview analysis indicated that these music teachers felt that they obtained their skills by trial and error, feeling that they accomplished the obtainment of skills by teaching themselves. Peer instruction was not a significant source of learning skills or applications. Those who had knowledgeable peers believed that it gave them a sense of security to know that someone could help them if they had a problem. It appears that like-minded peers encouraged and assisted each other with the results being increased motivation and success in using audio technology in engaging ways. The majority of music teachers believe that their technology skills are self-taught. Similarly, a significant majority credited their students for teaching them, often by indirect examples in the classroom. Many encourage experimentation by their students and then rely on them for determining the most efficient ways to incorporate utilization. Teachers who gained knowledge in using technology from their students believed that they still guided content and lesson focus.

Teachers believe that they are comfortable in obtaining the skills necessary to utilize digital audio technologies. The wide range of creative opportunities available and a desire to remain current and appear competent with their students motivated them. The teachers believe that alternative funding for equipment, significant web based materials, and the adoption of a 
new music curriculum with new CDs all contributed to their increase in skill in utilizing the technology.

The most positive formal instruction in audio technology was a result of corporately sponsored teacher workshops and training. One was a series of music notation demonstrations that were conducted throughout the state. The second was county training after adoption of the new curriculum series where teachers were given the opportunity to work alongside corporate educational trainers towards integrating materials contained in the new series. The skills gained and content were relevant to their teaching and inspirational towards adapting the software to their own use.

College course content and training was considered outdated, nonexistent, or not applicable or helpful in any way to obtaining skills. There was clear evidence that music teachers believe that they would better be able to obtain skills and utilize audio technologies if there was financial support for funding of equipment, replacing out of date equipment, and training.

Research question 4: What teaching decisions are made when using digital audio technologies and what impact do they have on student learning? All music teachers believed that digital audio technologies were valid and should be used in the teaching of music. This being said, teachers sought to integrate audio technologies into their teaching based on two primary reasons. The first reason was efficiency or flexibility in teaching and the second was the wealth of material available for classroom use in digital formats. These reasons have impacted the teaching decision process. Teachers have decided to use, to some extent, CD and digital files, MIDI files, an Ipod, and notation software because it made their teaching more efficient and engaged the students directly. Supplementary materials for advanced or beginning students as well as accompaniment recordings permitted the teachers greater to time to work with individual 
students as well as assess components not previously accessible when using analog technologies. Music teachers are using far greater audio materials in digital format than older more traditional teaching methodology. These resources, though overwhelming at times, were a strong motivational tool for electing to use the material. This has permitted easier and more frequent selection and manipulation of lesson appropriate material.

Teaching decisions made when using digital audio technologies involved changes in planning for integration and use which weighed the benefits for the students as well as the teachers. Often teachers will elect not to use audio technologies because of infrastructure and equipment issues or out of concern for the potential distraction of learning if the technology is used incorrectly.

WV Music educators believe that digital audio technologies have an effect on student learning. These paralleled their reasons for deciding to use the technology. The exposure to new material and variety of successful engagements with the musical material was enthusiastically promoted as impacting student learning positively. There is the perception that students were found to be more receptive and the opportunity to provide individualized instruction contributed to better student achievement. Students eagerly respond to the use of digital audio technologies and often promote its' use to the teachers.

The general population of music educators believed that using digital audio technologies helped them meet the Content Specific Objectives for technology use by students. Teachers were split equally when it came to operating and applying hardware to support learning. Likewise, there is a split amongst those who felt that they could create material which would enhance teaching strategies. There is a strong insecurity in making decisions regarding designing lessons and planning strategies that enhanced student learning. 
Research question 5: Has the use of digital audio technologies changed the teaching practices of WV public school music teachers? With the addition of the WV $21^{\text {st }}$ Century Learning Objectives, all are cognizant of the goals set forth by the state and working to integrate technology to their benefit. Teachers have adopted a wide variety of digital audio technology to their individual teaching modes. There is a preference towards modeling, and in-direct teaching when using the digital audio technologies. Direct teaching is still a predominant methodology with digital audio technologies serving as support mechanisms. Teachers have begun seeking technology engagements because of the type of student learner. There is a strong acknowledgement that the type of learner has changed and realization that the skill level of the students using digital audio processes often surpasses their own. This has resulted in many teachers not wanting to be left behind and has served as a catalyst for their own engagements with music technology in their classrooms. Teachers, especially in the upper grades, permit students to take an active role in the dissemination of in-class material via audio technology and prefer to guide them towards the lesson objectives as the student engages the technology.

WV music teachers found that using digital music technologies made them want to be better teachers. They are constantly reevaluating their teaching to adapt and adopt strategies which make them a better teacher as a result of their acknowledged perceptions of the benefits of the technology. Problem solving has become more efficient when using digital audio technologies. Music teachers welcomed the ability to engage their students in a technologically relevant manner and thus overcome a variety of problems. Whether the issue is one of maintaining interest in the general music classroom, solving rhythms problems in a performance, or encouraging their students to listen to material designed to promote the lesson objective, all 
agreed that using some sort of digital audio technology assisted positively and influenced the outcomes.

Teachers are leaning toward changing assessment methodologies as a result of the utilization of these technologies. While many are still transitioning to digital audio processes that support assessment, those who have completed the transition find that their expectations had increased significantly. Citing the ease of dissemination and access, predominantly in high school, teachers believed that students should have fewer barriers to learning required materials. Student learning did appear to improve but did not meet the heightened expectations of the teacher.

The WV music teachers also revealed their propensity to overcome obstacles when they felt the use of audio technologies were necessary. Several teachers are active in seeking alternative funding sources and innovative ways to surmount infrastructure issues.

Teaching practices have changed by the inclusion of new and significant content. Classroom efficiency has been improved and is more malleable as a result of using digital audio technologies. Teachers are far more receptive to the fact that student are immediately engaged with the use of such technologies and seek to use more for the purpose of maintaining student interests and thus focus. These different attitudes and views towards audio technologies mirror the influences described by Williams (2002) who discussed current media and our culture and the influence on modes of cognition and perception. WV music teachers are strongly aware of the new student learner. Teacher delivery systems and classrooms activities have become more efficient as a result of the utilization of digital audio technologies. 


\section{Implications}

While there is no correlation between geographic location and technology use there was evidence to suggest that the older and more experienced music teacher population might be more concerned with being left behind as a catalyst for their adoption of digital audio technologies. Although a majority of teachers have not pursued formal study beyond undergraduate work, they were eager to learn and develop digital audio technology skills.

Many of the digital audio technologies examined in this study are not being utilized to their fullest extent. WV music teachers have knowledge of such technologies but have only implemented those which fit their current infrastructure, are viewed as easy to use, or have been facilitated by their county or a third party. The perceived impact is that WV music teachers have not significantly moved beyond traditional applications of digital audio technologies. While a majority of music teachers are cognizant of what is available to utilize in potential support of their teaching, they have not implemented many of the technologies available to them. The usage rates in the areas of MIDI and computer sequencing when compared to other states, with similarly low reports of usage (Jassmann, 2004; Ohlenbusch, 2001; Sehmann \& Hayes, 1996), show West Virginia music teachers lagging behind in the integration and application of such technologies.

The teachers are primarily self-taught but would welcome proactive training based on grade level and appropriate digital audio technology. The majority of skill attainment has been by trial and error or as a result of third party training by corporate entities with vested interests in selling products within the state. This directly correlates with the findings of Reese (2003) who reported that Illinois teachers were less likely to get formal training in music technology applications and learned the most on their own or with colleagues. 
While these educational experiences have been fruitful, other attempts at training music educators in the use of digital audio technologies have been limited or deemed unsuccessful. While teacher training in technology has been an important issue (Cuban, 2001; Jones, 2000), WV music teachers seek training in the most effective instructional strategies towards using them.

As Rhee (2001) reported, obtaining skills and funding for technology are prominent themes in the incorporation of music technology for instruction. This is a priority for WV Music teachers who believe in the necessity for increased funding for equipment acquisition and infrastructure development. This is seen as the primary barrier for obtaining skills in and utilization of digital audio technologies. Teachers who push the boundaries have found external funding sources or have been forced to adapt to whatever usable technology is available to them.

Funding, equipment infrastructure, and training are very formal pressures which, when confronted by the teacher, present real challenges towards successful adoption and integration of digital audio technologies. Often these pressures, and others, such as mandated technology policies and expectations to meet $21^{\text {st }}$ century learning objectives and technology content standards, create real frustration and often obscure small shifts in successful attempts to implement technology engagements. For example, the recent and welcomed state supported new curriculum adoption has not been viewed in the context of financial support or progress though the adoption provided the benefit of placing some level of digital audio technologies into the hands of many music teachers.

Informal pressures diminish music teachers’ adoption of even basic audio technologies. Whether it is a lack of awareness as to where to start, or unfamiliarity with the wealth of training resources available, many $\mathrm{WV}$ music teachers cite personal time constraints as an implied barrier 
to incorporating technology within their teaching. Many have personal concerns as to how they will be perceived by both their colleagues and students. The student population and their comfort level with technology plays another informal pressure on music teachers as fears of appearing relevant and not succeeding in attempts at utilizing the technologies often cause teachers to lose sight of the benefits for choosing to create such new engagements. As WV music educators discuss formal and informal pressures in the context of how they experience their educational environment it becomes evident that many are beginning to surmount these obstacles.

WV music educators base their decisions to use digital audio technologies on the benefits of exposure to new materials, benefits in engagement of students, the access to far greater materials, and the technology skills of their current students. Despites these influences, most of the teachers are not currently involved in the use of advance digital audio technologies, which include MIDI applications, Internet dissemination, unique sources for audio materials, and digital audio recording/editing processes. All believe that digital audio technologies have a very positive impact on student learning and achievement.

Upitis (1992) observed that technology in the classroom affords educators to revise music teaching. West Virginia music educators are beginning to change their teaching practices based on the influence of digital audio technologies. While this change is gradual, more music teachers are becoming decisive in their use of audio technologies as an integral part of their teaching methodology. Teachers are now acknowledging the unique characteristics of the student learner as one who is comfortable with technology, immediately engages with material presented with a technology enhanced audio delivery system, and has learning expectations that revolve around the immediacy and stimulation provided by such an environment. Instruction now contains more content and is more efficient as result of the access, utilization of, and dissemination of digital 
audio technologies. The complexity of content has created a shift towards a more guided and constructionist method. This change, as initially reported by Webster (2002), is influencing the teaching practices of WV music teachers. WV teachers report that although they still utilize a direct teaching methodology, in-direct instruction with the teacher in a guidance role, is a methodology they are trying to embrace.

\section{Limitations}

The study focused on one primary area of technology, which was included as part of seven components as outlined by The Technology Institute for Music Educators. This study was directed towards the newest of these areas: digital audio and MIDI related technologies.

The survey was the primary tool for collecting data and as a basis for collecting and interpreting data obtained by the interviews and observations. The survey is limited by the reliability of self-reported data. Neither the survey nor the interview questions had been tested for validity or reliability.

The reliance on the self-reporting may lower the validity of the survey results. The interviews and observations were limited by the number and format of interview and observation opportunities and the amount of time spent during the observations. Multiple data sources in the method design minimized errors that may have arisen from a single technique. Twenty-four teachers were purposefully selected to participate in this research, providing a limited number of participants (Patton, 2002). Invitations to participants were based on their self-reporting of experience and skill in using digital audio technologies. External influences beyond teachers’ control, such as administrations’ requirements and availability of technology, may have influenced their decisions to use technology. 
The quantitative portion of this study was conducted at the end of the school year. At this time teachers are predominantly occupied with end-of-year activities and thus the response rate may have been significantly better if the teachers were given an opportunity to participate during a period where their attentions were focused on the general academic trajectory within the school year. The study was also dependent on initial communications via the state's RESA agencies. Direct communication with the active teachers without using a third party might have produced a greater response rate.

In a study of this type, all research information is filtered through the researcher. (Merriam, 1998). Based on this idea, the researcher's knowledge and experience in conducting this type of study, along with knowledge of audio technology and experience in using audio technology to teach, was a limitation. However, the researcher's musical experience helped him to judge the trustworthiness of the data analysis.

\section{Recommendations for Practice}

As a result of this study, the following general and specific actions are recommended to assist WV K-12 music teachers in their selection of digital audio technologies, promote the influence of audio technology use, heighten the effect on learning as a result of technology use, and remove both real and perceived barriers towards teacher’s skill attainment, personal engagement, and incorporation into instructional delivery.

Communication network. It is evident that there is no clear process for communicating directly to the population of this study (full-time Certified Public School Music Teachers currently teaching music in Grades K-12 in the State of West Virginia). While records kept by the WV State Department of Education are thorough, they are often filtered by achievement of content standards rather than by the position and certification held 
within each county. Identification through the eight Regional Education Service Agencies (RESA) remains uneven as a result of the level of interest and need within the larger objectives of each agency.

A better way to communicate with all music teachers would be an efficient and highly desirable asset. This might be best achieved by a yearly report of certifications held (specifically music endorsements) and full time music employees of each county board of education office. This information could be directed to a designated individual within each RESA for the establishment of database, mailing lists, listserv, web page, or other communication vehicle. Each RESA could then report communication data to a central location for use in statewide communication.

The Arts Coordinator within the Office of Instruction of the West Virginia Department of Education would most certainly benefit from any mechanism which might permit direct communication with all K-12 music educators. The advantages would include the ability to survey music teacher's desires for specific applications, perceived needs for training, promote innovative uses of digital audio technologies, and disseminate external funding opportunities.

Standards and curriculum. WV music teachers must familiarize themselves and perhaps formally adopt current recommended standards as promoted by the Music Educators National Conference (MENC) and the Technology Institute for Music Instruction (TI*ME). West Virginia music content standards correlate with the MENC Opportunity to Learn (OTL) Standards (MENC, 1994). There is the perception that current music teachers are not familiar with the correlation of the state's technology standards and the MENC OTL Standards for Music Technology (MENC, 1999) which provides information on curriculum, staffing, professional development, materials/ software, equipment, and facilities for implementing music technology 
from pre-school through grades 12.

Additionally, resources such as the MENC Strategies for Teaching: Technology (Reese et al., 2001) which contains over 100 examples of real world applications creatively using technology for music teaching should be provided to West Virginia music educators. The seven distinct applications of music technology established by The Technology Institute for Music Educators to enhance learning in each area of the national standards (Rudolph, 2004), should serve as a guide for teaching decisions towards implementations as well as infrastructure and training requirements.

Systematic training. As reported, a majority of respondents cited insufficient training as a barrier towards use of digital audio technologies in their teaching. There are several recommendations which would ameliorate this situation independently or more preferably, in tandem. The West Virginia Music Educators Association (WVMEA), at their annual conference, traditionally solicit presentations sponsored by hardware and software companies which have been beneficial in exposing music teachers to the possibilities of the product being presented. Often, little follow-up opportunities present themselves and hands-on engagements are limited by infrastructure. It is strongly encouraged that the WVMEA continue programming which addresses digital audio technologies and expand presentations to include individuals within the organization who have successfully integrated an aspect of the technology, or, who have had positive learning engagements as a result of integration. These best practice examples would permit a specific segment of the music teacher community (e.g., grade, environment, discipline) real opportunities to communicate, question, and learn.

The Technology Institute for Music Education offers a graded collection of courses for teachers to obtain levels of technology certification through $\mathrm{TI}^{*} \mathrm{ME}$ in many border states to 
West Virginia. Where possible, music teachers should be acknowledged for their participation whether it is by presentation opportunities, continuing education credit, reciprocal graduate credit, or even financial incentives. University’s and high schools, with appropriate infrastructure should seek to develop and host their own TI*ME offerings. This may present itself as an attractive vehicle for third party funding.

The traditional dissemination of information for teacher training often takes the form of workshop based instruction. This is in no fault of the presenters but a delivery which is guided by the infrastructure requirements necessary to efficiently work with larger groups of teachers. Quite different from this workshop format is a form of professional learning known as learning communities or communities of practice. The National Staff Development Council (2009) defines various sized learning groups who meet on a regular basis, for the purposes of learning, joint lesson planning, and problem solving. These teams commit to continuous improvement and experimentation to advance educational goals and student learning. The learning communities communicate frequently and strive to include the day-to-day professional conversations which hold instructional issues as their primary focus. Members of the community determine usefulness of additional learning, research, attend workshops, and seek external help based upon each member's strengths.

Researchers Riel and Fulton (2001), assert that there are many benefits from participating in learning communities. Significant interaction may be gained when like-minded groups utilize online mentoring and electronic networks. Professional collaboration is easily assisted by interactive lesson plan templates, multimedia databases, streamed video, web-conferencing, and e-mail.

At this writing, the learning community model will be introduced in West Virginia school 
systems at annual Summer Teacher Academies which serve public school educators of all grades and disciplines. These are traditionally offered at the beginning of the school year by county board offices and often in consort with the appropriate RESA office. The initiative for utilizing and promoting learning communities in the coming year has been directed from the office of the current West Virginia State Superintendent of Schools. The West Virginia Music Educators Association working in consort with the eight RESA locations and the Fine Arts Coordinator within the WV Office of Instruction should strongly embrace and encourage the development of learning communities in the training of WV music teachers and their use of digital audio technologies.

Other avenues which should be explored include the acquisition of proven training materials germane to teachers of music who use technology. Whether such materials be hard or electronic copy, or web-based tutorials, all materials should be congregated and loaned/accessed from a single central location. Additionally, when statewide or countywide music technology purchases include site licensing, the potential for vendor provided training should be explored.

Funding. While any significant funding for digital audio technologies directed at such a specialized group of teachers may be unrealistic, several steps might be taken to lessen the perception that lack of funding is one of the primary barriers to integration. While music teachers are often regarded as a separate entity, vehicles for obtaining funds to purchase classroom equipment is often haphazard based on each individual teacher. Funding sources often take the form of county appropriations, individual faculty senate or other school organization support, or parent organizations. A county by county protocol, specifying music technology purchases would begin the earmarking of funds for short and intermediate objectives and establish the consistency in obtaining funds yearly regardless of amount. Digital audio technology support 
should be included in any budget planning even if current funding sources do not exist. As previously stated, every attempt should be made to communicate potential external funding sources.

Equipment and software baselines. Using the seven distinct Technology Institute for Music Educators applications of technology which can enhance learning in each area of the national standards (Rudolph, 2004), a categorized list of standardized equipment and software should be adopted. Such a strategy might very well develop an economy of scale thereby producing a financial benefit as a result of large purchase quantities. Commitment to such baseline standardization could readily come from the recommendations of the aforementioned learning communities.

Electronic instruments, particularly keyboards, should contain the same sound sets, audio outputs, and key size and weight. Music notation software and related hardware should be of the same brand, appropriate version, and permit cross platform file exchanges. Similarly, standardization of MIDI and digital audio sequencing software and hardware would eliminate the need to learn and integrate multiple versions and would facilitate more efficient mastery of their use. Instructional software, identical in nature, should be selected based on the specific discipline finding it beneficial. For example, all middle school string programs should have access to the same library of auto accompaniments and readily share created accompaniments to all colleagues. Telecommunications and Internet access is readily available and relatively consistent within the entire state. Care should be taken that infrastructure issues such as bandwidth can support teaching engagements in which this is required. Multimedia materials, especially video, should be purchased in digital format and existing materials should be, where possible, converted to a similarly appropriate format. Information processing and lab management may remain out of 
the purview of music educators. Except in the rare cases of a dedicated music lab, the general protocol for lab management usually relies on individual teachers within each school building. Music teachers should seek out and begin proactively encouraging the use and support of musical activities within these locations.

Ideally, the three primary teaching environments would filter these selections and recommendations where music is taught. For example, a traveling teacher requires more portability and flexibility especially in the areas of interfaces, keyboards, and multi-media tools. Whereas a teacher with one classroom might utilize larger instruments, fixed speaker systems, mounted projection equipment, and peripherals such as printers, mounted microphones, and larger keyboards. If school systems are committed to using computer labs longer than five years, steps should be taken to provide consistent sound quality, web and CD based musical interactions, and musical keyboard interfaces.

Music teacher representation. West Virginia public school music teachers should seek out and embrace opportunities to serve on committees at the school, county, and RESA levels that address technology concerns and policies. While the West Virginia Music Educators Association has a technology chair within their executive board, opportunities for additional representation at the state level should be explored.

\section{Further Research}

For future research, the study can be extended to more specific West Virginia music teaching populations such as just elementary general or high school instrumental. This would permit the comparison of very specific teaching practices as they pertained to digital audio technologies. High and low self-rated audio technology users could be treated as separate subject groups providing a comparison analysis of teaching practice including contrasting methodologies 
used to meet the same content standards. The benefit or lack of benefit when using digital audio technologies might be more succinctly measured. It would also provide in clear detail what content students are learning and why specific teachers use or do not use available digital audio technologies. These success or failures might best be measured by the level of achievement towards meeting specific objectives contained within The MENC Opportunity to Learn (OTL) Standards (MENC, 1994) or the MENC OTL Standards for Music Technology (MENC, 1999).

During the study, questions were raised that could be answered in further studies. For instance, it would be interesting to investigate students', most likely middle or high school age, experiences and attitudes when participating in lessons which utilized significant digital audio technologies. This would provide further insight into how such engagements impacted them as well as an assessment as to whether specific content objectives were achieved. Similarly, it would be of additional interest to compare those students who had limited exposure to instruction which integrated audio technologies to those who had significant engagement.

This writer is currently examining WV College and University music technology course offerings and identifying similarities and differences with the curriculum content offered by the Technology Institute for Music Educators. The primary purpose for this examination is to identify primary themes and efficiencies in course content as it pertains to disseminating digital audio technology knowledge and practical skill attainment as well as needs for remediation, and adoption of current methodologies which might permit leap-frogging existing audio technology practices. This research could provide information and understanding for developing current training methods and improving future college courses. It is of considerable interest that participants in this study found that their formal degree instruction as it pertained to digital audio technologies was deemed outdated, nonexistent, or not applicable or helpful in any way to 
obtaining skills. An examination of curriculum and content in college preparation courses which address digital audio technology skills for music teachers would be beneficial for current teachers, future teachers, and the academic institutions preparing the future music educators. 


\section{References}

Apple Classrooms of Tomorrow (ACOT). (1996). Integrating technology into classroom instruction: An assessment of the impact of the ACOT teacher development center project (Report \#22). Apple Classrooms of Tomorrow: ACOT Library. Retrieved January 2, 2008, from http://www.apple.com/education/k12/leadership/acot/library.html

Adorno, T. (1958). Music and technique. Telos, 32, 80.

Alexander, D. (1990). Teaching in a MIDI studio. Electronic Music Educator, 19(4), 8-10.

Bartram, K. (2001). The development and implementation of a comprehensive introduction to music technology course for a secondary school (Doctoral dissertation, Shenandoah Conservatory, 2001). Dissertation Abstracts International, 62, 3984.

Bash, L. (1990). Visions warning: You may be replaced. The Music and Computer Educator, 1(5), 7-8.

Bauer, W., Reese, S., \& McAllister, P. (2003, Winter). Transforming music teaching via technology: The role of professional development. Journal of Research in Music Education, 51(4), 289-301.

Beckstead, D. (2001). Will technology transform music education? Music Educators Journal, 87(6), 44-49.

Berz, W.L., \& Bowman, J. (1995). An historical perspective on research (cycles in music computer-based technology). Bulletin of Council for Research in Music Education, 126, 15-28. 
Birge, E., Wilson, G., \& Gehrkens, K. (1938, February). Public school music, 1838-1938. Music Educators Journal, 24(4), 13-14.

Bowman, J. (1990). Training music teachers for the 21st century. The Music and Computer Educator, 1(1), 22-25.

Braun, H. (2002). Introduction: Technology and the production and reproduction of music in the 20th century. In H. Braun (Ed.), Music and Technology in the Twentieth Century. Baltimore, MD: The John Hopkins University Press.

Bremer, C. (1999). An update: Lessons learned from year one of the cooperative partnership in music technology. In S. Lipscomb (Ed.), Proceedings of the Sixth International Technological Directions in Music Learning Conference (pp. 7-9). San Antonio, Texas: IMR Press.

Brown, A. (1995). Digital technology and the study of music. International Journal of Music Education, 25(1), 14-19.

Brown, A. (1997). Changing technologies, Changing minds. In E. Gifford, A. Brown, and A. Thomas (Eds.), Conference proceedings of the ASME: XI National Conference. Australian Society for Music Education, Brisbane, Australia.

Cakewalk, (2008). Desktop music handbook. Glossary of MIDI and digital audio terms. Retrieved January 1, 2008 from http://www.cakewalk.com/Tips/desktop-glossary.asp Cawelti, G., \& Goldberg, M. (1997). Priorities for arts education research (Goals 2000 arts education partnership). Washington, DC: U.S. Department of Education. (Pamphlet)

Crab, S. (1995). 120 Years of electronic music. Retrieved January 2, 2008 from http://www.obsolete.com/120_years/nav.html 
Crow, B. (2006, March). Music creativity and the new technology. Music Education Research, 8(1), 121-130.

Cuban, L. (2001). Oversold \& underused: Computers in the classroom. Cambridge, MA: Harvard University Press.

Deutsch, H. (1993). Electroacoustic music: The first century. Miami, FL: Belwin Mills.

Dillman, D. (1978). Mail and telephone surveys. New York: John Wiley \& Sons.

Dwyer, D., Ringstaff, C., \& Sandholtz (1991). Changes in teachers' beliefs and practices in technology-rich classrooms. Educational Leadership, 48(8), 45-52. Retrieved November 12, 2007 from http://images.apple.com /education/k12 /leadership/ acot/pdf/rpt08.pdf

Eickmann, P. \& Fowler, C. (1971, January). Senses, media, and education. Music Educators Journal, 57(5), 33-35.

Estrella, S. (2004, November/December). Preparing tomorrow’s music teachers. Music Education Technology, 10, 12, 14, 16-17.

Feldstein, S. (2001). Music education and technology: Past, present, and future. Teaching Music, 9(3), 26-31.

Franklin, J. L. (1983). What's a computer doing in my music room? Music Educators Journal, 69(5), 29-32.

Forest, J. (1995). Music technology helps students succeed. Music Educators Journal, 82(2), 6773.

Garofalo, R. (1999, Autumn). From music publishing to mp3: Music and industry in the twentieth century. American Music, 17(3), 318-354.

Glatthorn, A. \& Joyner, R. (2005). Writing the winning thesis or dissertation. Thousand Oaks, CA: Corwin Press. 
Hackett, P. (1997). The musical classroom. Upper Saddle River, New Jersey: Prentice-Hall, Inc.

Heddon, S. \& Gordon, D. (1999, May). Computer usage among K-12 educators. Paper presented at the Southeastern Music Education Symposium, Athens, GA.

Hewlett-Packard Development Company, L.P. (2008). Digital music glossary. Retrieved January 1, 2008 from http://h71036.www7.hp.com/hho/cache/281-0-0-225-121.html

Higgins, W. (1992). Technology. In R. Colwell, (Ed.), Handbook of research on music teaching and learning. New York, NY: Schirmer Books.

Hoover, C. (1975). The history of music machines. New York NY: Drake Publishers.

ISTE. (2000). National educational technology standards. Retrieved August 15, 2007, from http://cnets.iste.org

Jaeschke, F. G. (1996). Creating music using electronic music technology: Curriculum materials and strategies for educators (Doctoral dissertation, Teachers College, Columbia University, 1996). Dissertation Abstracts International, 57, 2930.

Jassmann, Art E. (2004). The status of music technology in the K-12 curriculum of South Dakota public schools (Doctoral dissertation, University of South Dakota, 2004). Dissertation Abstracts International, 65, 1294.

Johnson, K. (2003, Spring). Teaching music with technology: Revisiting Apple’s ACOT study from a music teacher’s viewpoint. The Ti:mes, Technology Institute for Music Educators, 5(1). Retrieved October 1, 2007, from http://www.ti-me.org/members/newsletters.html Jones, G.R. (2000). Cyberschools: An education renaissance (2nd ed.). Englewood, CO: Cyber Publishing Group.

Jonson, G. (1915). Mechanical piano - players. Proceedings of the Musical Association: 42nd Session (1915-1916). (pp. 15-32). Oxford University Press. 
Kafai, Y. \& Resnick, M. (Eds.), (1996). Constructionism in practice: Designing, thinking, and learning in a digital world. Mahwah, NJ: Lawrence Earlbaum Publishers.

Kassner, K. (1998). Funding music technology. Music Educators Journal, 84(6), 30-36.

Leonhard, C. (1951, February-March). On the use of recordings. Music Educators Journal, 37(4), 48-49.

Leonhard, C. (1999, November). Grand masters series: A challenge for change in music education. Music Educators Journal, 86(3), 40-43.

Lin, P. (2005). The effects of integrating music technology into music teaching and learning and perceptions of students and teachers (Doctoral Dissertation), University of Idaho, 2005). Dissertation Abstracts International, 66, 0089.

Liske, K. (1999). Intellectual property rights guidelines for fair use of electronic music in music education. Update, 18(1), 21-25.

Mandinach, E.B., \& Cline, H. G. (1996). Classroom dynamics: The impact of a technologybased curriculum innovation on teaching and learning. Educational Computing Research, 14(1), 83-102.

Mark, M. (2002, September). A dynamic half century for music education. Music Educators Journal, 89(1), 17-18.

Mash, G. (1997). Computers and the music educator: A curriculum and resource guide. Menlo Park, CA.: Digidesign.

Mauricio, D. \& Oppenheimer, S. (2005). The MIDI-digital audio shuffle. Music Education Technology, 3(1), 10-13.

McCord, K. (2001). Music software for special needs. Music Educators Journal, 87(4), 30-35. Mecklenburger, J. (1986, Autumn). Emerging technologies for education. Peabody 
Journal of Education, 64(1), 183-187.

Meltzer, J. (2001). A survey to assess the technology literacy of undergraduate music majors at Big-10 universities: Implications for undergraduate courses in music education technology (Doctoral dissertation, University of Illinois, 2001). Dissertation Abstracts International, 62, 2709.

Meltzer, J. \& Reese, S. (1999, October). Using research to address issues of curriculum design for a music education technology course. Paper presented at the annual meeting of the Association for Technology in Music Instruction, Denver, CO.

MENC. (1994). The school music program: A new vision. Retrieved August 30, 2007, from http://www.menc.org/publications/books/prek12st.html

MENC. (1998). Research agenda for music education. Retrieved August 30, 2007, from http://www.menc.org/ information/research/ agenda.html

MENC. (1999). Opportunity-to-learn standards for music technology. Retrieved August 30, 2007, from http://www.menc.org/information/research/agenda.html

Merriam, S. B. (1998). Qualitative research and case study applications in education. San Francisco, CA: Jossey-Bass.

Miles, M. \& Huberman, A. (1994). Qualitative data analysis: An expanded sourcebook (2nd ed.). Thousand Oaks, CA: Sage.

Moore, B. (1992). Future technology working for education. Music Educators Journal, 79(3), 30-32.

Mumford, L. (1952). Art and technic. New York, NY: Columbia University Press.

NAMM. (1996). 1996 Music USA: NAMM global report. Carlsbad, CA: International Music Products Association. 
National Staff Development Council (NSDC). (2009). Learning communities. Retrieved June 1, 2009 from http://www.nsdc.org/standards/learningcommunities.cfm

NCATE. (2000). NCATE unit standards. Retrieved August 15, 2007, from http://www. ncate.org/institutions/standards.asp?ch=4

Ohlenbusch, G. (2001). A study of the use of technology applications by Texas Music Educators and the relevance to undergraduate music education curriculum. (Doctoral dissertation, Shenandoah Conservatory, 2001). Dissertation Abstracts International, 62, 957. (UMI No. 3010524)

Patton, M. Q. (1990). Qualitative evaluation and research methods (2nd ed.). Newbury Park, CA: Sage Publications.

Peters, G.D. (1992). Music software and emerging technology. Music Educators Journal, 19(3), 22-25, 63.

Powell, R. S. \& Artaud, A. (2001). Heard it on the web. Electronic Musician, 17(4), 120-129.

Reese, S. (1995). MIDI-assisted composing in your classroom. Music Educators Journal, 81(4), $38-40$.

Reese, S. (2003, Spring). Illinois schools and teachers make steady progress with music technology. The Ti:mes, Technology Institute for Music Educators, 5(1). Retrieved October 1, 2007, from http://www.ti-me.org/members/newsletters.html

Reese, S., McCord, K. \& Walls, K. (Eds.). (2001). Strategies for teaching technology. Reston, VA: MENC.

Reese, S., \& Rimington, J. (2000). Music technology in Illinois public schools. Update: Applications of Research in Music Education, 18(2), 27-32. 
Rhee, E. (2001). The incorporation of technology into music education in Korea: A mixed method study (Doctoral dissertation, Kent State University, 2001). Dissertation Abstracts International, 62, 3620.

Riel, M. \& Fulton, K. (2001, March). The role of technology in supporting learning communities. Phi Delta Kappan, 82(7), 518-523.

Riemer, B. (1989a, February). Music education as aesthetic education: Toward the future. Music Educators Journal, 75(6), 22-28.

Riemer, B. (1989b, March). Music education as aesthetic education: Toward the future. Music Educators Journal, 75(7), 26-32.

Riemer, B. (1989c). A philosophy of music education (2nd ed.). Upper Saddle River, New Jersey: Prentice- Hall Inc.

Rubin, D. (1995). The desktop musician: Creating music with your computer. Berkeley, CA: Osborne McGraw-Hill.

Rudolph, T. (1997). Music technology and the national standards. Retrieved August 1, 2007, from http://www.ti-me.rorg/members/articles/rudolph.html

Rudolph, T. (2004). Teaching music with technology (2nd ed.). Chicago, Illinois: GIA Publications.

Rudolph, T., Richmond, F., Mash, D., \& Williams, D. (1997). Technology strategies for music education. Wyncote, Pennsylvania: The Technology Institute for Music Educators.

Sarath, E. (1995). Is the paradigm shifting without us? The need for fundamental reform in contemporary musical training in the USA. International Journal of Music Education, 25, 29-37. 
Savage, J. (2005). Information communication technologies as a tool for re-imagining music education in the 21st century. International Journal of Education \& the Arts, 6(2). Retrieved January 4, 2008 from http://ijea.asu.edu/v6n2/

Schmidt, C. P. (1989). An investigation of undergraduate music education curriculum content. Bulletin of the Council for Research in Music Education, 99, 42-56.

Schoenherr, S. (1995). Recording technology history. Retrieved January 2, 2008 from http://history.sandiego.edu/gen/recording/notes.html

Sebald, D. (2003a, Spring). Technological change and the future of music education. The Ti:mes, Technology Institute for Music Educators, 5(1). Retrieved October 1, 2007, from http://www.ti-me.org/members/newsletters.html

Sebald, D. (2003b, Fall). Technological change and the future of music education: Part II. The Ti:mes, An Idea Whose Time has Come, 5(2), 6-7, 14.

Sehmann, K. \& Hayes, C. (1996). The status of computer technology in Kentucky's music classrooms. Unpublished manuscript, Eastern Kentucky University at Tichmond.

Stell, B. K. R. (1999). Technology: Its use and impact upon secondary music instruction in a Midwestern urban public school district (Doctoral Dissertation, University of Illinois, 1999). Dissertation Abstracts International, 60, 0684.

Taylor, T. (2001). Strange sounds: Music, technology, \& culture. New York, NY: Routledge Press.

Taylor, J. \& Deal, J. (1999). Integrating technology into the K-12 music curriculum: A pilot study of music teachers. In S. Lipscomb (Ed.), Proceedings of the Sixth International Technological Directions in Music Learning Conference (pp. 23-28). San Antonio, TX: IMR Press. 
Thompson, K. (1999). Internet resources for general music. Music Educators Journal, 86(3), 3035.

Tredway, C. B. (1994). A curriculum for the study of audio, video, computer, and electronic music technology for undergraduate music education majors based on a survey among members of the Florida Music Educators Association (Doctoral dissertation, The University of Southern Mississippi, 1994). Dissertation Abstracts International, 55-11A, 3894. (UMI No. 9509007)

Upitis, R. (1992). Technology and music: An intertwining dance. Computers In Education, 18(13), 243-250.

Van Regenmorter, M. (1998). Integrating technology into the music curriculum of a California community college (Masters of Arts thesis, California State University, 1998), Masters Abstracts International, 36(05), 1228. (UMI No. 1389332)

Wagner, M. (1988, October). Technology: A musical explosion. Music Educators Journal, 75(2), 30-33.

Waters, B. (1999). Ideas for effective web-based instruction. Music Educators Journal, 85(4), 13-17.

Watson, S. (2005). Picture this. Music Education Technology 3(4), 28-30.

Webster, P. (1992). Creative thinking, technology, and music education. Arts in Education, 12(2), 46-52.

Webster, P. (2002). Historical perspectives on technology and music, Music Educators Journal, 89(1), 38-43, 54.

Williams, D. B. (2004). Integrating music technology into the classroom. ECIS International Schools, 6(3), 33-39, 41. 
Williams, D. B., \& Webster, P. R. (1999). Experiencing Music Technology (2nd ed.). New York: Schirmer Books.

Willman, F. (1992). Music and computers coming of age. Music Educators Journal, 79(3), 21.

Wollenzien, T. J. (1999). An analysis of undergraduate music education curriculum in colleges and universities of the north central United States (Doctoral dissertation, University of Minnesota, 1999). Disssertation Abstracts International, 60,1957.

Wyman, R. (1966). Audio media in music education. Music Educators Journal, 52(4), 105-106, 108.

Yune, J. (1998). The effectiveness of computer assisted instruction in selected secondary schools in Los Angeles and orange counties of southern California (Doctoral dissertation, University of Southern California, 1998). Dissertation Abstracts International, 37, 0208. 
Appendices 


\section{Appendix A}

Survey of Digital Audio Technologies for Teaching and Learning 


\section{Use of Digital Audio Technologies for Teaching and Learning}

\section{Participant Code:}

Purpose: This survey is designed to gain a better understanding of how WV Music Educators use digital audio technologies in their classroom and their level of experience with the technology. The survey includes sections addressing hardware, software, skill, and teaching decisions. Responses will be kept strictly confidential and individual responses will not be identified or reported. Your participation is voluntary.

1. Check the Grade level(s) you are now teaching:

K-5 or K-6

Middle School or Junior High

9-12

2. Gender:

$\mathrm{F}$

$\mathrm{M}$

3. Years teaching experience in a public school setting: yrs

4. Highest degree or hours earned:

Bachelors

Masters

Hours Beyond Masters

Doctorate

5. County currently teaching in:

6. Which best describes your teaching environment?

1 school

Multiple schools

How many?

7. Average number of students taught during a single class session?

8. Average number of total students served in one day? 


\section{USE OF DIGITAL AUDIO TECHNOLOGIES IN MUSIC TEACHING ENVIRONMENTS}

Directions: For the following items please circle the one response that best reflects the extent to which you have utilized the digital audio technologies in each area.

9. Use of Audio Formats used in music instruction

$$
\begin{aligned}
& 1=\text { not at all } \\
& 2=\text { once a month or less } \\
& 3=\text { once a week } \\
& 4=\text { several times a week } \\
& 5=\text { every day }
\end{aligned}
$$

\begin{tabular}{llllll|} 
Records & 1 & 2 & 3 & 4 & 5 \\
Cassette Tapes & 1 & 2 & 3 & 4 & 5 \\
\hline Compact Discs & 1 & 2 & 3 & 4 & 5 \\
\hline MP3 (or other format) files & 1 & 2 & 3 & 4 & 5 \\
MIDI files & 1 & 2 & 3 & 4 & 5 \\
\hline Digital Audio Tapes & 1 & 2 & 3 & 4 & 5 \\
\hline Internet Streaming & 1 & 2 & 3 & 4 & 5 \\
Internet Radio & 1 & 2 & 3 & 4 & 5
\end{tabular}

10. Use of Digital Audio Devices used in music instruction

$$
\begin{aligned}
& 1=\text { not at all } \\
& 2=\text { once a month or less } \\
& 3=\text { once a week } \\
& 4=\text { several times a week } \\
& 5=\text { every day }
\end{aligned}
$$

\begin{tabular}{llllll} 
Use a stand alone electronic keyboard & 1 & 2 & 3 & 4 & 5 \\
Use a digital keyboard with MIDI Interface & 1 & 2 & 3 & 4 & 5 \\
Use a computer & 1 & 2 & 3 & 4 & 5 \\
Use an Internal audio interface & 1 & 2 & 3 & 4 & 5 \\
Use an External audio interface & 1 & 2 & 3 & 4 & 5 \\
Use wireless audio playback & 1 & 2 & 3 & 4 & 5 \\
\hline Use wired audio playback & 1 & 2 & 3 & 4 & 5 \\
Use a CD Burner & 1 & 2 & 3 & 4 & 5 \\
Use a DVD Burner & 1 & 2 & 3 & 4 & 5 \\
Use a DAT recorder & 1 & 2 & 3 & 4 & 5 \\
Use Sound modules and sample players & 1 & 2 & 3 & 4 & 5 \\
Use an iPod or other MP3 player & 1 & 2 & 3 & 4 & 5
\end{tabular}


11. Use of Digital Audio Technology Processes and Activities used in music instruction

$1=$ not at all

$2=$ once a month or less

$3=$ once a week

$4=$ several times a week

$5=$ every day

\begin{tabular}{llllll} 
Created or Sequenced a MIDI file & 1 & 2 & 3 & 4 & 5 \\
\hline Utilized interactive CD-ROMs & 1 & 2 & 3 & 4 & 5 \\
\hline Used the Internet to disseminate digital audio samples & 1 & 2 & 3 & 4 & 5 \\
\hline Used the Internet to disseminate MIDI files & 1 & 2 & 3 & 4 & 5 \\
\hline Purchased digital audio files for educational use? & 1 & 2 & 3 & 4 & 5 \\
Purchased CDs for educational use & 1 & 2 & 3 & 4 & 5 \\
Created CDs of audio material to disseminate to my students. & 1 & 2 & 3 & 4 & 5 \\
Created CDs of audio material to use in the classroom. & 1 & 2 & 3 & 4 & 5 \\
Used I-Tunes music store & 1 & 2 & 3 & 4 & 5 \\
Downloaded Public Domain MIDI files & 1 & 2 & 3 & 4 & 5 \\
Downloaded Public Domain audio files & 1 & 2 & 3 & 4 & 5 \\
Downloaded files from a file sharing site & 1 & 2 & 3 & 4 & 5 \\
Obtained audio media from a friend or colleague & 1 & 2 & 3 & 4 & 5
\end{tabular}

12. Use of Digital Audio Technology Software used in music instruction

$1=$ not at all

$2=$ once a month or less

$3=$ once a week

$4=$ several times a week

$5=$ every day

$\begin{array}{llllll}\text { Digital Audio editing software } & 1 & 2 & 3 & 4 & 5 \\ \text { CD Duplication software } & 1 & 2 & 3 & 4 & 5 \\ \text { Midi Sequencing software } & 1 & 2 & 3 & 4 & 5 \\ \text { MP3 software } & 1 & 2 & 3 & 4 & 5 \\ \text { Digital Audio recording/editing software } & 1 & 2 & 3 & 4 & 5 \\ \text { Windows OS } & 1 & 2 & 3 & 4 & 5 \\ \text { Mac OS } & 1 & 2 & 3 & 4 & 5 \\ \text { Internal Computer sounds } & 1 & 2 & 3 & 4 & 5 \\ \text { Software Synthesizer instruments } & 1 & 2 & 3 & 4 & 5 \\ \text { Instrument samples } & 1 & 2 & 3 & 4 & 5\end{array}$


13. How would you rate your current ability in each of the following areas?

$1=$ Never Tried

2=Beginner

$3=$ Intermediate

4=Advanced

\begin{tabular}{lllll} 
Use CDs in the classroom & 1 & 2 & 3 & 4 \\
\hline Use CD-ROMs in the classroom & 1 & 2 & 3 & 4 \\
Create my own CDs from other CDs & 1 & 2 & 3 & 4 \\
Create CDs of other audio sources & 1 & 2 & 3 & 4 \\
\hline Used MP3 files or other audio file format (WMA, etc) & 1 & 2 & 3 & 4 \\
\hline Used Midi file & 1 & 2 & 3 & 4 \\
Create a MIDI file & 1 & 2 & 3 & 4 \\
Edit an audio file & 1 & 2 & 3 & 4 \\
Download a piece of written music (PDF or other format) & 1 & 2 & 3 & 4 \\
Download a midi file & 1 & 2 & 3 & 4 \\
Use the Internet to disseminate audio information & 1 & 2 & 3 & 4 \\
Use a web page to disseminate audio information & 1 & 2 & 3 & 4 \\
Use digital audio hardware & 1 & 2 & 3 & 4 \\
\hline Use digital audio software & 1 & 2 & 3 & 4 \\
Use an I-pod or Podcast & 1 & 2 & 3 & 4 \\
Purchase music from a commercial download site & 1 & 2 & 3 & 4 \\
Download music from a file sharing site & 1 & 2 & 3 & 4 \\
Download music files in the public domain (I.e.; Library of Congress) & 1 & 2 & 3 & 4 \\
Use Internet radio in the classroom & 1 & 2 & 3 & 4 \\
\hline Use a DAT recorder & 1 & 2 & 3 & 4 \\
Record Internet radio or music streaming services & 1 & 2 & 3 & 4
\end{tabular}


14. Please respond to the following statements regarding Education and Teaching Decisions.

\begin{tabular}{|l|c|c|}
\hline Digital Audio Technologies were taught in my undergraduate study. & $\mathrm{Y}$ & $\mathrm{N}$ \\
\hline Digital Audio Technologies were taught in my undergraduate study. & $\mathrm{Y}$ & $\mathrm{N}$ \\
\hline $\begin{array}{l}\text { I have participated in "in Service” workshops which contained digital } \\
\text { audio tech instruction. }\end{array}$ & $\mathrm{Y}$ & $\mathrm{N}$ \\
\hline $\begin{array}{l}\text { I have attended summer workshops which were specifically designed } \\
\text { toward learning digital audio technologies. }\end{array}$ & $\mathrm{Y}$ & $\mathrm{N}$ \\
\hline I have received instruction on digital audio technologies from my peers. & $\mathrm{Y}$ & $\mathrm{N}$ \\
\hline I have received instruction on digital audio technologies from my students. & $\mathrm{Y}$ & $\mathrm{N}$ \\
\hline I have received instruction on digital audio technologies from the Internet. & $\mathrm{Y}$ & $\mathrm{N}$ \\
\hline $\begin{array}{l}\text { I currently use digital audio technologies to meet CSO standards for use of } \\
\text { technology by students. }\end{array}$ & $\mathrm{Y}$ & $\mathrm{N}$ \\
\hline $\begin{array}{l}\text { I currently use digital audio technologies meet CSO standards for music } \\
\text { knowledge by students. }\end{array}$ & $\mathrm{Y}$ & $\mathrm{N}$ \\
\hline $\begin{array}{l}\text { I currently use digital audio technologies because of their ease of } \\
\text { dissemination. }\end{array}$ & $\mathrm{Y}$ & $\mathrm{N}$ \\
\hline $\begin{array}{l}\text { I currently use digital audio technologies because they make audio } \\
\text { teaching tools more accessible. }\end{array}$ & $\mathrm{Y}$ & $\mathrm{N}$ \\
\hline $\begin{array}{l}\text { I currently use digital audio technologies because they permit audio } \\
\text { teaching materials to be more easily edited and customized. }\end{array}$ & $\mathrm{Y}$ & $\mathrm{N}$ \\
\hline $\begin{array}{l}\text { I have designed specific lessons or activities that utilize digital audio } \\
\text { technologies. }\end{array}$ & $\mathrm{Y}$ & $\mathrm{N}$ \\
\hline $\begin{array}{l}\text { I can plan strategies using digital audio technologies to enhance my } \\
\text { students learning. }\end{array}$ & $\mathrm{Y}$ & $\mathrm{N}$ \\
\hline I can create digital audio materials that will enhance my teaching strategies & $\mathrm{Y}$ & $\mathrm{N}$ \\
\hline I use digital audio technologies to support student centered activities. & $\mathrm{Y}$ & $\mathrm{N}$ \\
\hline I can operate and apply applicable hardware to support student learning. & $\mathrm{Y}$ & $\mathrm{N}$ \\
\hline $\begin{array}{l}\text { I have a familiarity with copyright and Fair Use laws for using digital } \\
\text { audio examples for education. }\end{array}$ & $\mathrm{Y}$ & $\mathrm{N}$ \\
\hline
\end{tabular}

15. Are you willing to talk with the researcher about your use of Digital Audio Technologies as a Public School Music Teacher? Yes No

16. Are you willing to participate in classroom observations? Yes No If you answered yes to question 15 or 16 please complete the following: Name:

Phone:

Email: 
Appendix B

Interview Protocol 


\section{Introductory Script}

To be read before the beginning of any interview:

My name is Mark Williams and I am conducting this interview as partial fulfillment of my Doctorate degree in Technology Education at West Virginia University. Dr. Neal Shambaugh, Associate Professor of Instructional Design and Technology in the WVU Department of Human Resources and Education is serving as my primary advisor and committee chair throughout this process. If at any time you would like more information regarding this study please do not hesitate to contact me via the address, email, or phone number I am providing you.

Thank you for agreeing to participate in my dissertation research. The overall purpose of my study is to understand the use of digital audio technologies by West Virginia music educators. More specifically, your personal experiences and application of digital technologies used in your teaching.

Before we begin, I would like to point out the following:

1. Your participation is entirely voluntary.

2. Interviews will be audio-taped and participants will not be labeled with your name.

3. Transcripts of the interview and the audio-tape will be destroyed after one year.

4. You may request a copy of the transcript of your interview.

5. You may refuse to answer any question, or ask that tape recording be stopped at any time.

6. Your employment status will be not affected by your refusal to participate or by your withdrawal from the interview.

7. Your interview should take between 30 minutes and one hour to conduct.

\section{Interview Question format:}

1. What factors have impeded or contributed to your use and implementation of digital audio technologies.

2. Are you comfortable learning new audio technologies?

3. How did you come to learn these skills?

4. How is it that digital audio technologies have influenced your teaching methods?

5. What teaching decisions do you make when you use digital audio technologies?

6. Are these decisions different than when using an older technology/ How? 
7. How have digital audio technologies helped students to learn?

8. Are there audio technologies that you are familiar with that you would never use? Why?

9. Have new audio technologies caused you to re-evaluate your teaching?

10. Do you assess outcomes differently as a result of using digital audio technologies? 
Appendix C

Observation Elements 


\section{OBSERVATION NOTES}

Date:

Participant Code:

Location (e.g. computer lab, classroom, library/media center)

Lesson:

\section{Observation elements:}

\section{Educational Strategies}

a. Type of teaching strategy (direct, modeling, interactive, facilitating)

b. Focus: (Technology or Lesson)

c. Doe the technology support the lesson objectives?

\section{Familiarity with the Technology}

d. Is the teacher comfortable using the technology?

\section{Influence on Teaching}

e. How is the teacher facilitating the technology?

f. What were student reactions and teacher adjustments?

g. Was the activity/lesson successful 


\section{Appendix D}

Institutional Review Board Exemption 


\section{WestVirginiaUniversity. \\ Office of Research Compliance}

\section{Expedited - IRB Protocol - Exemption}

To: $\quad$ Shambaugh, Neal

From: $\quad$ WVU Office of Research Compliance

Date: Wednesday, May 07, 2008

Subject: No action required

Tracking \#: $\mathrm{H}-20886$

Title: $\quad$ WV Public School Music Teachers' Use of Digital Audio Technologies for Teaching and Learning

The above-referenced study was reviewed by the Institutional Review Board and was granted exemption on 5/7/2008 in accordance with 45 CFR 46.101(2).

While no action is required on your part, the IRB made the following findings:

This research study was granted an exemption in accordance with Research that involves educational tests, survey procedures, interview procedures or observation of public behavior [45 CFR 46.101(2)]. If you have questions please refer to the IRB website.

The following documents have been approved and validated for use in this study and are available in the BRAAN system:

cover letter interview script

Thank you.

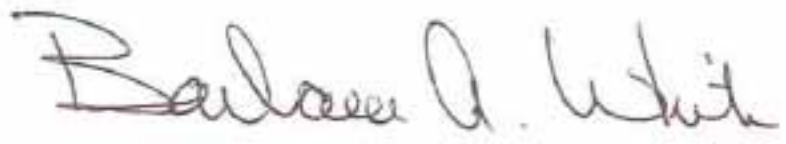

Board Designee: White, Barbara

Letter Sent By: White, Barbara, 5/7/2008 2:26 PM

Once you begin your human subject research the following regulations apply:

1. Unanticipated or serious adverse events/side effects encountered in this research study must be reported to the IRB within five (5) days. 
2. Any modifications the study protocol or informed consent form must be reviewed and approved by the IRB prior to implementation.

3. You may not use a modified informed consent form until it has been approved and validated by the IRB. 